\title{
Room temperature C-H arylation of benzofurans by aryl iodides
}

Authors: Amy L. Mayhugh ${ }^{\mathrm{a}}$ and Christine K. Luscombe*,a, b

a.Department of Chemistry, University of Washington, Seattle, WA 98195.

b. Department of Materials Science \& Engineering, University of Washington, Seattle, WA 98195.

*Corresponding Author

Email: Christine Luscombe - luscombe@uw.edu

\section{Table of Contents}

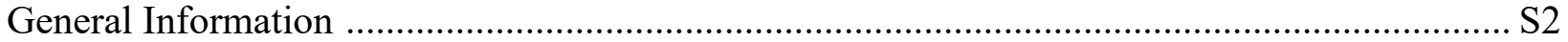

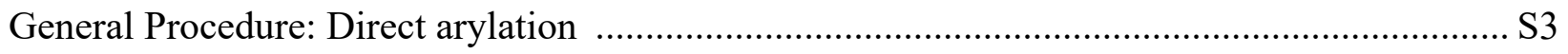

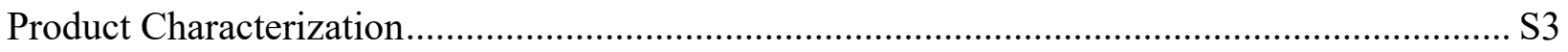

Starting Material Preparation................................................................................................ S10

Heteroatom Comparison (Table S1, Table S2) ................................................................... S12

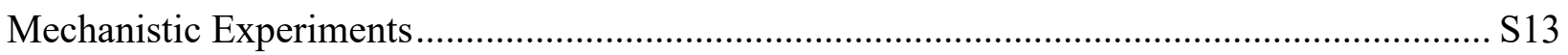

Deuterium Exchange............................................................................................. S13

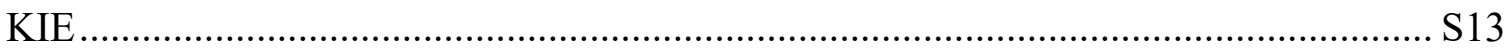

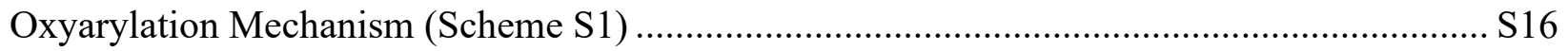

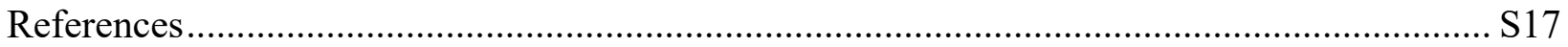

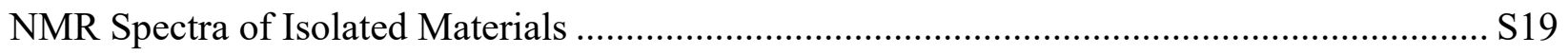




\section{General Information:}

All reactions were carried out under nitrogen atmosphere using standard Schlenk techniques unless otherwise noted. NMR spectra were recorded on Bruker AV-300 and AV-500 spectrometers operating at 300 and $500 \mathrm{MHz}$, respectively. ${ }^{1} \mathrm{H}$ NMR chemical shifts $(\delta)$ are reported in parts per million (ppm) downfield of tetramethylsilane and are referenced relative to the residual solvent signal $\left(\mathrm{CDCl}_{3}(7.26 \mathrm{ppm})\right.$, DMSO- $\left.d_{6}(2.50)\right) .{ }^{13} \mathrm{C}$ NMR chemical shifts $(\delta)$ are reported in parts per million (ppm) downfield of tetramethylsilane and are referenced relative to the residual solvent signal $\left(\mathrm{CDCl}_{3}(77.16 \mathrm{ppm})\right.$, DMSO-d 6 (39.52 ppm)). When indicated, 1,3-dinitrobenzene was used as an internal standard for quantitative NMR. An Agilent 5973 Gas Chromatograph - Mass Spectrometer (EI) was used to perform GC-MS analysis. An AB Sciex 5600 Mass Spectrometer was used for HRMS analysis. HFIP was dried on $4 \AA$ molecular sieves and sparged with nitrogen prior to use. Deuterated solvents were stored over $4 \AA$ molecular sieves. Ethylene carbonate was stored under nitrogen between uses. All other reagents, catalysts, and chemicals were purchased from Sigma-Aldrich or Tokyo Chemical International and used without purification. Column chromatography was performed using VWR Common Silica Gel 60 Á. 


\section{Representative Procedure: Direct arylation}

To an oven-dried vial and stir bar was added $\mathrm{Pd}(\mathrm{OAc})_{2}(2.5 \mathrm{~mol} \%, 0.025 \mathrm{mmol}, 5.6 \mathrm{mg}), \mathrm{Ag}_{2} \mathrm{O}$ (0.75 equiv, $0.75 \mathrm{mmol}, 173.3 \mathrm{mg}$ ), 2-nitrobenzoic acid (1.5 equiv, $1.5 \mathrm{mmol}, 250.7 \mathrm{mg}$ ) (solid iodoarenes are added at this point as well). The vial was evacuated and backfilled with $\mathrm{N}_{2}$ three times. Hexafluoro-2-propanol was added ( $1 \mathrm{M}, 1 \mathrm{~mL})$, followed by benzofuran (1 equiv, $1 \mathrm{mmol}$ ) and iodobenzene ( 2 equiv, $2 \mathrm{mmol}$ ) ). The reaction was allowed to stir at room temperature (22 ${ }^{\circ} \mathrm{C}$ ) for $16 \mathrm{~h}$. After this time, the reaction mixture was filtered through a silica plug using $\mathrm{CH}_{2} \mathrm{Cl}_{2}$ to transfer and subsequently concentrated under reduced pressure. Purification was performed using column chromatography (hexanes/DCM). 2-phenylbenzo[b]furan was isolated in $82 \%$

\section{Product Characterization:}<smiles>c1ccc(-c2cc3ccccc3o2)cc1</smiles>

2-phenylbenzo[b]furan (3a):

Product 3a was prepared according to the general procedure (158 mg, 82\% yield) and obtained as a white solid. The data is in accordance with the literature. ${ }^{1}$

$\mathrm{R}_{\mathrm{f}}=0.32$ (hexanes)

${ }^{1} \mathrm{H}$ NMR $\left(500 \mathrm{MHz}, \mathrm{CDCl}_{3}\right) \delta 7.88(\mathrm{~d}, J=8.4 \mathrm{~Hz}, 2 \mathrm{H}), 7.59(\mathrm{~d}, J=8.2 \mathrm{~Hz}, 1 \mathrm{H}), 7.53(\mathrm{~d}, J=8.1$ $\mathrm{Hz}, 1 \mathrm{H}), 7.46$ (t, $J=7.8 \mathrm{~Hz}, 2 \mathrm{H}), 7.36(\mathrm{t}, J=7.4 \mathrm{~Hz}, 1 \mathrm{H}), 7.31-7.27(\mathrm{~m}, 1 \mathrm{H}), 7.23(\mathrm{~d}, J=14.8$ $\mathrm{Hz}, 1 \mathrm{H}), 7.03$ (s, 1H).

${ }^{13} \mathrm{C} \mathrm{NMR}\left(126 \mathrm{MHz}, \mathrm{CDCl}_{3}\right) \delta 156.1,155.0,130.6,129.4,128.9,125.1,124.4,123.1,121.0$, $111.3,101.4$.

GC-MS (EI) calculated for [M]+ 194.2, found 194.2

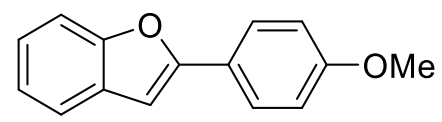

\section{2-(4-methoxyphenyl)benzo[b]furan (3b):}

Product 3b was prepared according to the general procedure (158 mg, 68\% yield) and obtained as a white solid. The data is in accordance with the literature. ${ }^{1}$

$\mathrm{R}_{\mathrm{f}}=0.57$ (50\% DCM in hexanes)

${ }^{1} \mathrm{H}$ NMR $\left(500 \mathrm{MHz}, \mathrm{CDCl}_{3}\right) \delta 7.80(\mathrm{dd}, J=9.0,2.3 \mathrm{~Hz}, 2 \mathrm{H}), 7.55(\mathrm{~d}, J=7.4 \mathrm{~Hz}, 1 \mathrm{H}), 7.50(\mathrm{~d}, J$ $=8.0 \mathrm{~Hz}, 1 \mathrm{H}), 7.26-7.19(\mathrm{~m}, 2 \mathrm{H}), 6.98(\mathrm{dd}, J=9.0,2.3 \mathrm{~Hz}, 2 \mathrm{H}), 6.91-6.86(\mathrm{~m}, 1 \mathrm{H}), 3.87(\mathrm{~s}$, $3 \mathrm{H})$.

${ }^{13} \mathrm{C}$ NMR $\left(126 \mathrm{MHz}, \mathrm{CDCl}_{3}\right) \delta 160.1,156.2,154.9,129.6,126.6,123.9,123.5,123.0,120.7$, 114.4, 111.1, 99.8, 55.5.

GC-MS (EI) calculated for [M]+224.1, found 224.1

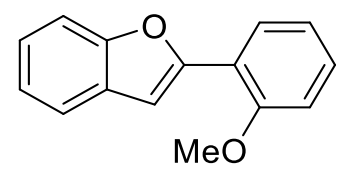

\section{2-(2-methoxyphenyl)benzo[b]furan (3c):}

Product 3c was prepared according to the general procedure (119 $\mathrm{mg}, 52 \%$ yield) and obtained as a white solid. The data is in accordance with the literature. ${ }^{2}$ 
$\mathrm{R}_{\mathrm{f}}=0.28(5 \% \mathrm{DCM}$ in hexanes)

${ }^{1} \mathrm{H}$ NMR $\left(300 \mathrm{MHz}, \mathrm{CDCl}_{3}\right) \delta 8.08(\mathrm{~d}, J=9.2 \mathrm{~Hz}, 1 \mathrm{H}), 7.55(\mathrm{dd}, J=25.1,7.1 \mathrm{~Hz}, 2 \mathrm{H}), 7.41-$ $7.30(\mathrm{~m}, 3 \mathrm{H}), 7.25-7.17(\mathrm{~m}, 1 \mathrm{H}), 7.16-6.99(\mathrm{~m}, 2 \mathrm{H}), 4.02(\mathrm{~s}, 3 \mathrm{H})$.

${ }^{13} \mathrm{C} \mathrm{NMR}\left(126 \mathrm{MHz}, \mathrm{CDCl}_{3}\right) \delta 156.6,154.0,152.3,129.9,129.4,127.2,124.2,122.8,121.2$, $120.9,119.5,111.2,110.9,106.5,55.5$.

GC-MS (EI) calculated for [M]+224.1, found 224.2<smiles>Cc1ccc(-c2cc3ccccc3o2)cc1</smiles>

\section{2-(4-methylphenyl)benzo[b]furan (3d):}

Product 3d was prepared according to the general procedure ( $147 \mathrm{mg}, 66 \%$ yield) and obtained as a white solid. The data is in accordance with the literature. ${ }^{3}$

$\mathrm{R}_{\mathrm{f}}=0.21$ (hexanes)

${ }^{1} \mathrm{H}$ NMR $\left(500 \mathrm{MHz}, \mathrm{CDCl}_{3}\right) \delta 7.76(\mathrm{~d}, J=8.2 \mathrm{~Hz}, 2 \mathrm{H}), 7.52-7.48(\mathrm{~m}, 1 \mathrm{H}), 7.27(\mathrm{~d}, J=6.3 \mathrm{~Hz}$, $3 \mathrm{H}), 7.22(\mathrm{td}, J=7.5,1.0 \mathrm{~Hz}, 1 \mathrm{H}), 6.97(\mathrm{~s}, 1 \mathrm{H}), 2.40(\mathrm{~s}, 3 \mathrm{H})$.

${ }^{13} \mathrm{C} \mathrm{NMR}\left(126 \mathrm{MHz}, \mathrm{CDCl}_{3}\right) \delta 156.4,154.9,138.7,129.6,129.5,127.9,125.1,124.1,123.0$, 120.9, 111.2, 100.7, 21.5.

GC-MS (EI) calculated for [M]+ 208.1, found 208.1

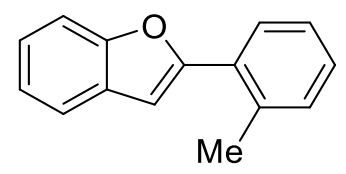

\section{2-(2-methylphenyl)benzo[b]furan (3e):}

Product 3e was prepared according to the general procedure (181.4 mg, 85\% yield) and obtained as a clear oil. The data is in accordance with the literature. ${ }^{3}$

$\mathrm{R}_{\mathrm{f}}=0.29$ (hexanes)

${ }^{1} \mathrm{H}$ NMR $\left(500 \mathrm{MHz}, \mathrm{CDCl}_{3}\right) \delta 7.90(\mathrm{~d}, J=7.9 \mathrm{~Hz}, 1 \mathrm{H}), 7.65(\mathrm{~d}, J=8.2 \mathrm{~Hz}, 1 \mathrm{H}), 7.58(\mathrm{~d}, J=8.1$ $\mathrm{Hz}, 1 \mathrm{H}), 7.38-7.26(\mathrm{~m}, 5 \mathrm{H}), 6.94(\mathrm{~s}, 1 \mathrm{H}), 2.63(\mathrm{~s}, 3 \mathrm{H})$.

${ }^{13} \mathrm{C}$ NMR $\left(126 \mathrm{MHz}, \mathrm{CDCl}_{3}\right) \delta 155.8,154.5,135.9,131.4,130.1,129.3,128.6,128.3,126.2$, $124.4,122.9,121.0,111.2,105.2,22.1$.

GC-MS (EI) calculated for [M]+208.1, found 208.1<smiles>CCNc1ccc(-c2cc3ccccc3o2)cc1</smiles>

$N$-[4-(2-benzofuranyl)phenyl]acetamide (3f):

Product $3 \mathbf{f}$ was prepared according to the general procedure with the following modifications: 1 equiv 4-iodoacetamide was used. Product $3 f$ was obtained in (221 mg, 87\% yield) as a tan solid. The data is in accordance with the literature. ${ }^{4}$

$\mathrm{R}_{\mathrm{f}}=0.64$ (EtOAc)

${ }^{1} \mathrm{H}$ NMR $\left(500 \mathrm{MHz}, \mathrm{DMSO}-d_{6}\right) \delta 10.14(\mathrm{~s}, 1 \mathrm{H}), 7.85(\mathrm{~d}, J=8.6 \mathrm{~Hz}, 2 \mathrm{H}), 7.72(\mathrm{~d}, J=8.6 \mathrm{~Hz}$, 2H), $7.62(\mathrm{dd}, J=16.1,7.7 \mathrm{~Hz}, 2 \mathrm{H}), 7.35-7.21(\mathrm{~m}, 3 \mathrm{H}), 2.08(\mathrm{~s}, 3 \mathrm{H})$.

${ }^{13} \mathrm{C}$ NMR (126 MHz, DMSO) $\delta$ 168.5, 155.3, 154.1, 139.9, 129.0, 125.3, 124.4, 124.2, 123.1, $120.9,119.1,110.9,100.7,24.1$.

GC-MS (EI) calculated for [M]+ 251.1, found 251.1 
OP

4-(2-Benzofuranyl)benzyl alcohol (3g):

Product $\mathbf{3 g}$ was prepared according to the general procedure with the following modifications: 1 equiv 4-iodobenzyl alcohol was used. Product $\mathbf{3 g}$ was obtained (201 $\mathrm{mg}, 90 \%$ yield) as a yellow solid. The data is in accordance with the literature. ${ }^{4}$

$\mathrm{R}_{\mathrm{f}}=0.19(\mathrm{DCM})$

${ }^{1} \mathrm{H}$ NMR $\left(500 \mathrm{MHz}, \mathrm{CDCl}_{3}\right) \delta 7.90(\mathrm{~s}, 1 \mathrm{H}), 7.80(\mathrm{~d}, J=7.8 \mathrm{~Hz}, 1 \mathrm{H}), 7.62-7.57(\mathrm{~m}, 1 \mathrm{H}), 7.55-$ $7.50(\mathrm{~m}, 1 \mathrm{H}), 7.45(\mathrm{~d}, J=15.3 \mathrm{~Hz}, 1 \mathrm{H}), 7.36(\mathrm{~d}, J=7.6 \mathrm{~Hz}, 1 \mathrm{H}), 7.29(\mathrm{td}, J=8.2,7.7,1.4 \mathrm{~Hz}$, $1 \mathrm{H}), 7.24$ (td, $J=7.5,1.0 \mathrm{~Hz}, 1 \mathrm{H}), 7.06(\mathrm{~s}, 1 \mathrm{H}), 4.79(\mathrm{~s}, 2 \mathrm{H})$.

${ }^{13} \mathrm{C} \mathrm{NMR}\left(126 \mathrm{MHz}, \mathrm{CDCl}_{3}\right) \delta 155.8,155.0,141.4,130.9,129.2,127.2,124.5,124.3,123.5$, 123.1, 121.1, 111.3, 101.7, 65.3.

GC-MS (EI) calculated for [M]+ 224.1, found 224.2<smiles>c1ccc2c(c1)OC1c3ccccc3OC21</smiles>

\section{4b,9b-dihydrobenzofuro[3,2-b]benzofuran (4):}

Product 4 was prepared according to the general with the following modifications: 1 equiv 2iodophenol was used. Product 4 was obtained in $(210 \mathrm{mg}, 99 \%$ yield) as a yellow solid. When prepared according to the general procedure, 4 was obtained in $67 \%$ yield. The data is in accordance with the literature. ${ }^{5}$

$\mathrm{R}_{\mathrm{f}}=0.33(10 \%$ DCM in hexanes)

${ }^{1} \mathrm{H}$ NMR $\left(500 \mathrm{MHz}, \mathrm{CDCl}_{3}\right) \delta 7.54(\mathrm{~d}, J=7.5 \mathrm{~Hz}, 1 \mathrm{H}), 7.28(\mathrm{td}, J=8.1,7.6,1.3 \mathrm{~Hz}, 2 \mathrm{H}), 6.97$ $(\mathrm{td}, J=7.5,0.9 \mathrm{~Hz}, 1 \mathrm{H}), 6.87(\mathrm{~d}, J=8.2 \mathrm{~Hz}, 1 \mathrm{H}), 6.29(\mathrm{~s}, 1 \mathrm{H})$.

${ }^{13} \mathrm{C}$ NMR $\left(126 \mathrm{MHz}, \mathrm{CDCl}_{3}\right) \delta 160.2,131.5,124.6,121.3,111.0,86.6$.

GC-MS (EI) calculated for [M]+210.1, found 210.1

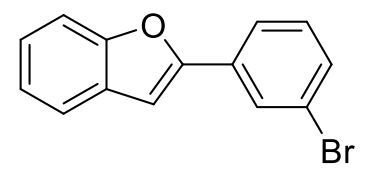

\section{2-(3-bromophenyl)benzo[b]furan (3i):}

Product 3i was prepared according to the general procedure $(247 \mathrm{mg}, 86 \%$ yield) and obtained as a white solid. The data is in accordance with the literature. ${ }^{6}$

$\mathrm{R}_{\mathrm{f}}=0.26$ (hexanes)

${ }^{1} \mathrm{H}$ NMR $\left(500 \mathrm{MHz}, \mathrm{CDCl}_{3}\right) \delta 8.02(\mathrm{t}, J=1.8 \mathrm{~Hz}, 1 \mathrm{H}), 7.79(\mathrm{dt}, J=7.8,1.0 \mathrm{~Hz}, 1 \mathrm{H}), 7.60(\mathrm{~d}, J=$ $8.3 \mathrm{~Hz}, 1 \mathrm{H}), 7.55-7.50(\mathrm{~m}, 1 \mathrm{H}), 7.47(\mathrm{ddd}, J=7.9,1.9,0.9 \mathrm{~Hz}, 1 \mathrm{H}), 7.36-7.28(\mathrm{~m}, 2 \mathrm{H}), 7.24$ $(\mathrm{d}, J=7.4 \mathrm{~Hz}, 1 \mathrm{H}), 7.05(\mathrm{~s}, 1 \mathrm{H})$.

${ }^{13} \mathrm{C} \mathrm{NMR}\left(126 \mathrm{MHz}, \mathrm{CDCl}_{3}\right) \delta 155.0,154.2,132.4,131.3,130.3,129.0,127.8,124.8,123.4$, 123.2, 123.0, 121.2, 111.3, 102.5.

GC-MS (EI) calculated for $[\mathrm{M}]+272.0$, found 272.0 


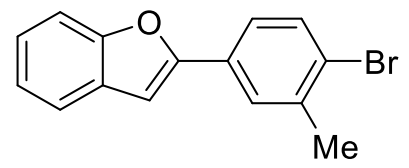

2-(4-bromo-3-methylphenyl)benzo[b]furan (3j):

Product 3j was prepared according to the general procedure in $(242 \mathrm{mg}, 84 \%$ yield $)$ and obtained as a white solid.

$\mathrm{R}_{\mathrm{f}}=0.28$ (hexanes)

${ }^{1} \mathrm{H}$ NMR $\left(500 \mathrm{MHz}, \mathrm{CDCl}_{3}\right) \delta 7.74(\mathrm{~s}, 1 \mathrm{H}), 7.56(\mathrm{~d}, J=33.3 \mathrm{~Hz}, 4 \mathrm{H}), 7.29(\mathrm{~s}, 1 \mathrm{H}), 7.23(\mathrm{~s}, 1 \mathrm{H})$, $7.02(\mathrm{~s}, 1 \mathrm{H}), 2.48(\mathrm{~s}, 3 \mathrm{H})$.

${ }^{13} \mathrm{C}$ NMR $\left(126 \mathrm{MHz}, \mathrm{CDCl}_{3}\right) \delta 155.2,138.5,132.9,129.8,129.3,127.2,125.2,124.6,123.9$, 123.2, 121.1, 111.3, 101.8, 23.2.

GC-MS (EI) calculated for [M]+286.0, found 286.0<smiles>Clc1ccc(-c2cc3ccccc3o2)cc1</smiles>

\section{2-(4-chlorophenyl)benzo[b]furan (3k):}

Product 3k was prepared according to the general procedure with the following modifications: the reaction was run for $20 \mathrm{~h}$. Product $3 \mathrm{k}$ was obtained (182 $\mathrm{mg}, 80 \%$ yield) as a white solid. The data is in accordance with the literature. ${ }^{1}$

$\mathrm{R}_{\mathrm{f}}=0.26$ (hexanes)

${ }^{1} \mathrm{H}$ NMR $\left(500 \mathrm{MHz}, \mathrm{CDCl}_{3}\right) \delta 7.82-7.78(\mathrm{~m}, 2 \mathrm{H}), 7.59(\mathrm{~d}, J=7.5 \mathrm{~Hz}, 1 \mathrm{H}), 7.52(\mathrm{~d}, J=8.2 \mathrm{~Hz}$, $1 \mathrm{H}), 7.45-7.40(\mathrm{~m}, 2 \mathrm{H}), 7.30(\mathrm{td}, J=8.3,7.8,1.3 \mathrm{~Hz}, 1 \mathrm{H}), 7.24(\mathrm{td}, J=7.6,0.9 \mathrm{~Hz}, 1 \mathrm{H}), 7.02$ $(\mathrm{s}, 1 \mathrm{H})$.

${ }^{13} \mathrm{C}$ NMR $\left(126 \mathrm{MHz}, \mathrm{CDCl}_{3}\right) \delta 155.1,154.9,134.5,129.2,129.2,129.1,126.3,124.7,123.3$, 121.2, 111.4, 101.9.

GC-MS (EI) calculated for [M]+ 228.0, found 228.1<smiles>Fc1ccc(-c2cc3ccccc3o2)cc1</smiles>

\section{2-(4-fluorophenyl)benzo[b]furan (3l):}

Product 31 was prepared according to the general procedure in (201 $\mathrm{mg}, 94 \%$ yield $)$ and obtained as a white solid. The data is in accordance with the literature. ${ }^{3}$

$\mathrm{R}_{\mathrm{f}}=0.23$ (hexanes)

${ }^{1} \mathrm{H}$ NMR $\left(500 \mathrm{MHz}, \mathrm{CDCl}_{3}\right) \delta 7.88-7.81(\mathrm{~m}, 2 \mathrm{H}), 7.58(\mathrm{~d}, J=7.6 \mathrm{~Hz}, 1 \mathrm{H}), 7.51(\mathrm{~d}, J=8.8 \mathrm{~Hz}$, $1 \mathrm{H}), 7.29(\mathrm{td}, J=8.2,7.7,1.4 \mathrm{~Hz}, 1 \mathrm{H}), 7.25-7.20(\mathrm{~m}, 1 \mathrm{H}), 7.15(\mathrm{t}, J=8.7 \mathrm{~Hz}, 2 \mathrm{H}), 6.96(\mathrm{~s}$, $1 \mathrm{H})$.

${ }^{13} \mathrm{C} \mathrm{NMR}\left(126 \mathrm{MHz}, \mathrm{CDCl}_{3}\right) \delta 164.0,162.0,155.2,155.0,129.3,126.9,126.9,124.4,123.2$, 121.0, 116.1, 115.9, 111.3, 101.1.

GC-MS (EI) calculated for [M]+212.1, found 212.1

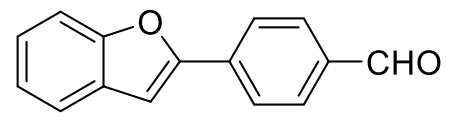

4-(2-benzofuranyl)benzaldehyde (3m): 
Product 3m was prepared according to the general procedure (176.1 $\mathrm{mg}, 80 \%$ yield) and obtained as a yellow solid.

$\mathrm{R}_{\mathrm{f}}=0.52(50 \% \mathrm{DCM}$ in hexanes $)$

${ }^{1} \mathrm{H} \mathrm{NMR}\left(500 \mathrm{MHz}, \mathrm{CDCl}_{3}\right) \delta 10.04(\mathrm{~s}, 1 \mathrm{H}), 8.03(\mathrm{~d}, J=8.3 \mathrm{~Hz}, 2 \mathrm{H}), 7.96(\mathrm{~d}, J=8.4 \mathrm{~Hz}, 2 \mathrm{H})$, $7.64(\mathrm{~d}, J=7.7 \mathrm{~Hz}, 1 \mathrm{H}), 7.56(\mathrm{~d}, J=8.9 \mathrm{~Hz}, 1 \mathrm{H}), 7.35(\mathrm{t}, J=8.4 \mathrm{~Hz}, 1 \mathrm{H}), 7.28(\mathrm{t}, J=8.2 \mathrm{~Hz}$, $1 \mathrm{H}), 7.21(\mathrm{~s}, 1 \mathrm{H})$. The data is in accordance with the literature. ${ }^{7}$

${ }^{13} \mathrm{C} \mathrm{NMR}\left(126 \mathrm{MHz}, \mathrm{CDCl}_{3}\right) \delta 191.5,155.3,154.3,135.9,135.9,130.3,128.8,125.4,125.2$, 123.4, 121.5, 111.4, 104.3.

GC-MS (EI) calculated for [M]+ 222.1, found 222.1<smiles>COC(=O)c1ccc(-c2cc3ccccc3o2)cc1</smiles>

\section{Methyl 4-(benzofuran-2-yl)benzoate (3n):}

Product 3n was prepared according to the general procedure with the following modifications: the reaction was run for $20 \mathrm{~h}$; the mixture obtained after column chromatography was recrystallized in hexanes. Product 3n was obtained (198 mg, 77\% yield) as white needles. The data is in accordance with the literature. ${ }^{8}$

$\mathrm{R}_{\mathrm{f}}=0.58(\mathrm{DCM})$

${ }^{1} \mathrm{H}$ NMR $\left(500 \mathrm{MHz}, \mathrm{CDCl}_{3}\right) \delta 8.12(\mathrm{~d}, J=8.7 \mathrm{~Hz}, 2 \mathrm{H}), 7.93(\mathrm{~d}, J=8.3 \mathrm{~Hz}, 2 \mathrm{H}), 7.62(\mathrm{~d}, J=8.8$ $\mathrm{Hz}, 1 \mathrm{H}), 7.54(\mathrm{~d}, J=8.8 \mathrm{~Hz}, 1 \mathrm{H}), 7.36-7.30(\mathrm{~m}, 1 \mathrm{H}), 7.27(\mathrm{~d}, J=0.9 \mathrm{~Hz}, 1 \mathrm{H}), 7.16(\mathrm{~s}, 1 \mathrm{H})$, $3.95(\mathrm{~s}, 3 \mathrm{H})$.

${ }^{13} \mathrm{C} \mathrm{NMR}\left(126 \mathrm{MHz}, \mathrm{CDCl}_{3}\right) \delta 166.8,155.3,154.8,134.6,130.3,129.9,129.1,125.2,124.8$, 123.4, 121.4, 111.5, 103.6, 52.3.

GC-MS (EI) calculated for [M]+ 252.1, found 252.1

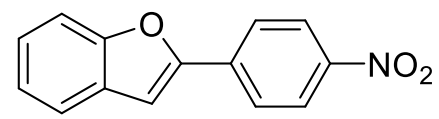

\section{2-(4-nitrophenyl)benzo[b]furan (3o):}

Product 30 was prepared according to the general procedure with the following modifications: the reaction was run for $20 \mathrm{~h}$ at $50{ }^{\circ} \mathrm{C}$ (using an oil bath). Product 30 was obtained ( $84 \mathrm{mg}, 35 \%$ yield) as a yellow solid. The data is in accordance with the literature. ${ }^{6}$

$\mathrm{R}_{\mathrm{f}}=0.15(20 \%$ DCM in hexanes)

${ }^{1} \mathrm{H}$ NMR $\left(500 \mathrm{MHz}, \mathrm{CDCl}_{3}\right) \delta 8.30(\mathrm{~d}, J=9.0 \mathrm{~Hz}, 2 \mathrm{H}), 7.99(\mathrm{~d}, J=9.0 \mathrm{~Hz}, 2 \mathrm{H}), 7.65(\mathrm{~s}, 1 \mathrm{H})$, $7.55(\mathrm{~s}, 1 \mathrm{H}), 7.39-7.35(\mathrm{~m}, 1 \mathrm{H}), 7.30-7.26(\mathrm{~m}, 1 \mathrm{H}), 7.24-7.21(\mathrm{~m}, 1 \mathrm{H})$.

${ }^{13} \mathrm{C}$ NMR $\left(126 \mathrm{MHz}, \mathrm{CDCl}_{3}\right) \delta 155.6,153.4,147.4,136.4,128.8,126.0,125.3,124.4,123.7$, 121.8, 111.6, 105.2.

GC-MS (EI) calculated for [M]+239.1, found 239.1

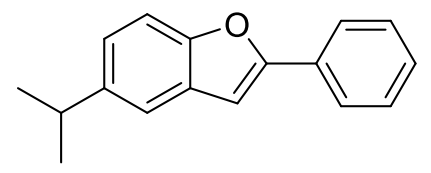

\section{5-isopropyl-2-phenylbenzo[b]furan (3p):}

Product 3p was prepared according to the general procedure ( $112.3 \mathrm{mg}, 48 \%$ yield $)$ and obtained as a white solid.

$\mathrm{R}_{\mathrm{f}}=0.22$ (hexanes) 
${ }^{1} \mathrm{H}$ NMR $\left(500 \mathrm{MHz}, \mathrm{CDCl}_{3}\right) \delta 7.86(\mathrm{dd}, J=8.3,1.2 \mathrm{~Hz}, 2 \mathrm{H}), 7.47-7.41(\mathrm{~m}, 4 \mathrm{H}), 7.37-7.31$ $(\mathrm{m}, 1 \mathrm{H}), 7.18-7.14(\mathrm{~m}, 1 \mathrm{H}), 7.00-6.96(\mathrm{~m}, 1 \mathrm{H}), 3.02$ (hept, $J=6.9 \mathrm{~Hz}, 1 \mathrm{H}), 1.31$ (d, $J=6.9$ $\mathrm{Hz}, 6 \mathrm{H})$.

${ }^{13} \mathrm{C}$ NMR $\left(126 \mathrm{MHz}, \mathrm{CDCl}_{3}\right) \delta 156.2,153.7,143.9,130.8,129.4,128.9,128.5,125.0,123.4$, 118.2, 110.9, 101.5, 34.3, 24.7.

HRMS calculated 237.1273, found 237.1280.<smiles>Brc1ccc2oc(-c3ccccc3)cc2c1</smiles>

\section{5-bromo-2-phenylbenzo[b]furan (3q):}

Product 3q was prepared according to the general procedure (246 $\mathrm{mg}, 87 \%$ yield) and obtained as a white solid. The data is accordance with the literature. ${ }^{9}$

$\mathrm{R}_{\mathrm{f}}=0.26$ (hexanes)

${ }^{1} \mathrm{H}$ NMR $\left(300 \mathrm{MHz}, \mathrm{CDCl}_{3}\right) \delta 7.85(\mathrm{~d}, J=7.5 \mathrm{~Hz}, 2 \mathrm{H}), 7.73-7.68(\mathrm{~m}, 1 \mathrm{H}), 7.46(\mathrm{t}, J=7.5 \mathrm{~Hz}$, $2 \mathrm{H}), 7.39(\mathrm{t}, J=3.4 \mathrm{~Hz}, 3 \mathrm{H}), 6.96(\mathrm{~s}, 1 \mathrm{H})$.

${ }^{13} \mathrm{C}$ NMR $\left(126 \mathrm{MHz}, \mathrm{CDCl}_{3}\right) \delta 157.4,153.8,131.4,130.1,129.2,129.0,127.2,125.2,123.6$, $116.2,112.8,100.8$.

GC-MS (EI) calculated for [M]+272.0, found 272.1

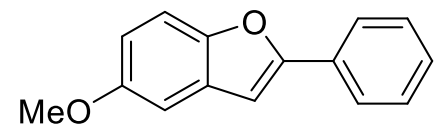

\section{5-methoxy-2-phenylbenzo[b]furan (3r):}

Product 3r was prepared according to the general procedure (163.1 mg, 74\% yield) and obtained as a white solid. The data is in accordance with the literature. ${ }^{10}$

$\mathrm{R}_{\mathrm{f}}=0.31(50 \%$ DCM in hexanes)

${ }^{1} \mathrm{H}$ NMR $\left(500 \mathrm{MHz}, \mathrm{CDCl}_{3}\right) \delta 7.88-7.82(\mathrm{~m}, 2 \mathrm{H}), 7.48-7.38(\mathrm{~m}, 3 \mathrm{H}), 7.35(\mathrm{t}, J=7.4 \mathrm{~Hz}, 1 \mathrm{H})$, $7.05(\mathrm{~d}, J=2.6 \mathrm{~Hz}, 1 \mathrm{H}), 6.97(\mathrm{~s}, 1 \mathrm{H}), 6.89(\mathrm{dd}, J=8.9,2.6 \mathrm{~Hz}, 1 \mathrm{H}), 3.86(\mathrm{~s}, 3 \mathrm{H})$.

${ }^{13} \mathrm{C} \mathrm{NMR}\left(126 \mathrm{MHz} \mathrm{CDCl}_{3}\right) \delta 156.9,156.2,150.1,130.7,129.9,128.9,128.6,125.0,113.1$, 111.7, 103.5, 101.6, 56.1.

GC-MS (EI) calculated for [M]+ 224.1, found 224.1

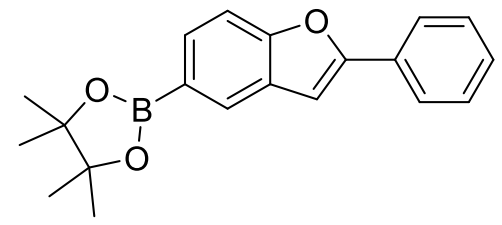

\section{2-phenyl-5-(4,4,5,5-tetramethyl-1,3,2-dioxaborolan-2-yl)benzo[b]furan (3s):}

Product 3s was prepared according to the general procedure (132.5 mg, $41 \%$ yield) and obtained as a clear viscous oil.

$\mathrm{R}_{\mathrm{f}}=0.64(\mathrm{DCM})$

${ }^{1} \mathrm{H}$ NMR $\left(500 \mathrm{MHz}, \mathrm{CDCl}_{3}\right) \delta 8.10(\mathrm{~s}, 1 \mathrm{H}), 7.88(\mathrm{dd}, J=8.4,1.2 \mathrm{~Hz}, 2 \mathrm{H}), 7.77(\mathrm{dd}, J=8.2,1.1$ $\mathrm{Hz}, 1 \mathrm{H}), 7.55-7.52(\mathrm{~m}, 1 \mathrm{H}), 7.46(\mathrm{t}, J=7.7 \mathrm{~Hz}, 2 \mathrm{H}), 7.38-7.34(\mathrm{~m}, 1 \mathrm{H}), 7.03(\mathrm{~s}, 1 \mathrm{H}), 1.39$ (s, $12 \mathrm{H})$.

${ }^{13} \mathrm{C}$ NMR $\left(126 \mathrm{MHz}, \mathrm{CDCl}_{3}\right) \delta 157.2,156.1,131.0,130.5,129.1,128.9,128.7,128.4,125.1$, $110.8,101.5,83.9,25.1$. 
HRMS calculated 321.1656, found 321.1659.

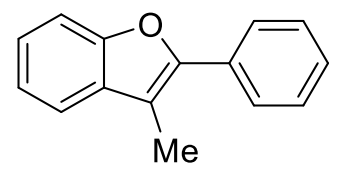

\section{3-methyl-3-phenylbenzo[b]furan (3t):}

Product $3 \mathbf{t}$ was prepared according to the general procedure (177 $\mathrm{mg}, 82 \%$ yield) and obtained as a clear oil. The data is in accordance with the literature. ${ }^{11}$

$\mathrm{R}_{\mathrm{f}}=0.25$ (hexanes)

${ }^{1} \mathrm{H}$ NMR $\left(500 \mathrm{MHz}, \mathrm{CDCl}_{3}\right) \delta 7.84(\mathrm{~d}, J=9.3 \mathrm{~Hz}, 2 \mathrm{H}), 7.57(\mathrm{~d}, J=7.4 \mathrm{~Hz}, 1 \mathrm{H}), 7.50(\mathrm{t}, J=7.7$ $\mathrm{Hz}, 3 \mathrm{H}), 7.38(\mathrm{t}, J=7.4 \mathrm{~Hz}, 1 \mathrm{H}), 7.34-7.26(\mathrm{~m}, 2 \mathrm{H}), 2.51(\mathrm{~s}, 3 \mathrm{H})$.

${ }^{13} \mathrm{C} \mathrm{NMR}\left(126 \mathrm{MHz}, \mathrm{CDCl}_{3}\right) \delta 153.9,150.8,131.6,131.3,128.7,128.0,126.8,124.4,122.5$, $119.4,111.4,111.0,9.5$.

GC-MS (EI) calculated for [M]+ 208.1, found 208.1<smiles></smiles>

\section{9-methoxy-2-phenyl-7H-furo[3,2-g][1]benzopyran-7-one (3u):}

Product $3 \mathbf{u}$ was prepared according to the general procedure with the following modifications: the reaction was run for $20 \mathrm{~h}$ at $50{ }^{\circ} \mathrm{C}$ (using an oil bath). Product $3 \mathbf{u}$ was obtained $(219 \mathrm{mg}, 82 \%$ yield) as a yellow solid. The data is in accordance with the literature. ${ }^{12}$

$\mathrm{R}_{\mathrm{f}}=0.79$ (EtOAc)

${ }^{1} \mathrm{H}$ NMR (500 MHz, $\left.\mathrm{CDCl}_{3}\right) \delta 7.90-7.84(\mathrm{~m}, 2 \mathrm{H}), 7.76(\mathrm{~d}, J=9.6 \mathrm{~Hz}, 1 \mathrm{H}), 7.48$ (t, $J=7.6 \mathrm{~Hz}$, $2 \mathrm{H}), 7.41(\mathrm{t}, J=7.4 \mathrm{~Hz}, 1 \mathrm{H}), 7.32(\mathrm{~s}, 1 \mathrm{H}), 7.04(\mathrm{~s}, 1 \mathrm{H}), 6.38(\mathrm{~d}, J=9.6 \mathrm{~Hz}, 1 \mathrm{H}), 4.38(\mathrm{~s}, 3 \mathrm{H})$. ${ }^{13} \mathrm{C}$ NMR $\left(75 \mathrm{MHz}, \mathrm{CDCl}_{3}\right) \delta 160.5,158.1,147.7,146.7,144.3,132.7,129.6,129.4,129.1$, 128.0, 125.2, 116.8, 114.8, 112.6, 101.0, 61.4 .

GC-MS (EI) calculated for [M]+ 292.1, found 292.1 


\section{Starting Material Preparation:}

All iodoarenes and benzofuran substrates not listed were purchased commercially.<smiles>CC(C)c1ccc2occc2c1</smiles>

\section{5-isopropylbenzo[b]furan (1b):}

Starting material $\mathbf{1 b}$ was prepared according to the literature procedure, ${ }^{13}$ and collected in $95 \%$ yield as a clear liquid.

$\mathrm{R}_{\mathrm{f}}=0.63(50 \% \mathrm{DCM}$ in hexanes)

${ }^{1} \mathrm{H}$ NMR $\left(500 \mathrm{MHz}, \mathrm{CDCl}_{3}\right) \delta 7.50(\mathrm{~s}, 1 \mathrm{H}), 7.38-7.31(\mathrm{~m}, 2 \mathrm{H}), 7.28-7.13(\mathrm{~m}, 2 \mathrm{H}), 7.09(\mathrm{dd}, J$ $=8.5,1.8 \mathrm{~Hz}, 1 \mathrm{H}), 6.63(\mathrm{~d}, J=2.7 \mathrm{~Hz}, 1 \mathrm{H}), 2.94(\mathrm{~s}, 1 \mathrm{H}), 1.21(\mathrm{~s}, 6 \mathrm{H})$.

${ }^{13} \mathrm{C}$ NMR (126 MHz, $\left.\mathrm{CDCl}_{3}\right) \delta 153.7,145.1,143.6,127.6,123.3,118.4,111.1,106.6,34.2,24.7$. GC-MS (EI) calculated for [M]+ 160.1, found 160.1<smiles>COc1ccc2occc2c1</smiles>

\section{5-methoxybenzo[b]furan (1c):}

Starting material $1 \mathbf{c}$ was prepared according to the literature procedure, ${ }^{13}$ and collected in $40 \%$ yield as a yellow liquid. The data is accordance with the literature.

$\mathrm{R}_{\mathrm{f}}=0.48(50 \% \mathrm{DCM}$ in hexanes)

${ }^{1} \mathrm{H}$ NMR (500 MHz, $\left.\mathrm{CDCl}_{3}\right) \delta 7.59(\mathrm{~d}, J=2.1 \mathrm{~Hz}, 1 \mathrm{H}), 7.39(\mathrm{~d}, J=8.9 \mathrm{~Hz}, 1 \mathrm{H}), 7.06(\mathrm{~d}, J=2.6$

$\mathrm{Hz}, 1 \mathrm{H}), 6.90(\mathrm{dd}, J=8.9,2.6 \mathrm{~Hz}, 1 \mathrm{H}), 6.71(\mathrm{~d}, J=2.8 \mathrm{~Hz}, 1 \mathrm{H}), 3.85(\mathrm{~s}, 3 \mathrm{H})$.

${ }^{13} \mathrm{C}$ NMR $\left(126 \mathrm{MHz}, \mathrm{CDCl}_{3}\right) \delta 156.1,150.12,145.9,128.1,113.2,111.9,106.8,103.7,56.0$.

GC-MS (EI) calculated for [M] +148.1 , found 148.2<smiles>Brc1coc2ccccc12</smiles>

\section{3-bromobenzo[b]furan (1d):}

Starting material 1d was prepared according to the literature report: ${ }^{14}$

$\mathrm{Br}_{2}$ (46.53 mmol, $2.38 \mathrm{~mL}$ ) dissolved in $\mathrm{CH}_{2} \mathrm{Cl}_{2}(15 \mathrm{~mL})$ was added dropwise to a solution containing benzo[b]furan $(42.3 \mathrm{mmol}, 4.66 \mathrm{~mL})$ in $\mathrm{CH}_{2} \mathrm{Cl}_{2}(100 \mathrm{~mL})$ at $-10{ }^{\circ} \mathrm{C}$. The mixture was stirred for $1 \mathrm{~h}$ at $-10{ }^{\circ} \mathrm{C}$, then $\mathrm{NaOH}(1 \mathrm{M}, 5 \mathrm{~mL})$ was added. The mixture was diluted with $\mathrm{H}_{2} \mathrm{O}$ $(200 \mathrm{~mL})$ and saturated $\mathrm{Na}_{2} \mathrm{~S}_{2} \mathrm{O}_{3}(100 \mathrm{~mL})$ was added. The solution was extracted 3 times with $\mathrm{CH}_{2} \mathrm{Cl}_{2}$. The combined organic layers were dried over $\mathrm{MgSO}_{4}$, filtered, and concentrated under reduced pressure. The crude product was taken up in $\mathrm{EtOH}(100 \mathrm{~mL})$. Saturated $\mathrm{KOH}$ in $\mathrm{EtOH}$ $(100 \mathrm{~mL})$ was added dropwise at $0{ }^{\circ} \mathrm{C}$. The flask was heated to reflux for $4 \mathrm{~h}$ in an oil bath. After the time had elapsed, the reaction was cooled to room temperature and $\mathrm{H}_{2} \mathrm{O}(50 \mathrm{~mL})$ was added. The $\mathrm{EtOH}$ was removed under reduced pressure and the aqueous solution was extracted with EtOAc. The organic layer was washed with $\mathrm{H}_{2} \mathrm{O}$ and brine, dried over $\mathrm{MgSO}_{4}$, filtered, and concentrated under reduced pressure. The mixture was purified by column chromatography using hexanes as eluent, affording $1 \mathbf{a}-\boldsymbol{d}-\mathbf{2}$ as white crystals (4.784 g, $58 \%$ yield).

$\mathrm{R}_{\mathrm{f}}=0.62$ (hexanes) 
${ }^{1} \mathrm{H} \mathrm{NMR}\left(500 \mathrm{MHz}, \mathrm{CDCl}_{3}\right) \delta 7.66(\mathrm{~s}, 1 \mathrm{H}), 7.56(\mathrm{~d}, J=6.8 \mathrm{~Hz}, 1 \mathrm{H}), 7.50(\mathrm{~d}, J=7.7 \mathrm{~Hz}, 1 \mathrm{H})$, $7.39-7.31(\mathrm{~m}, 2 \mathrm{H})$.

${ }^{13} \mathrm{C}$ NMR (126 MHz, $\left.\mathrm{CDCl}_{3}\right) \delta 154.5,142.8,127.3,125.6,123.6,119.9,111.9,98.1$.

GC-MS (EI) calculated for [M]+196.0, found 196.0<smiles>[2H]c1cc2ccccc2o1</smiles>

\section{Benzo[b]furan-2-d (2d-1a):}

1a- $\boldsymbol{d}$-2 was prepared based on the literature report: ${ }^{15} n-\mathrm{BuLi}(2.5 \mathrm{M}$ in hexanes, $14.7 \mathrm{mmol}, 5.90$ $\mathrm{mL})$ was added dropwise with vigorous stirring to a solution containing benzo[ $b]$ furan $(8.15$ mmol, $0.9 \mathrm{~mL})$ in THF $(27.2 \mathrm{~mL})$ at $-78^{\circ} \mathrm{C}$. The mixture was stirred for $2 \mathrm{~h}$ at $-78{ }^{\circ} \mathrm{C}$, then $\mathrm{D}_{2} \mathrm{O}$ $(4.5 \mathrm{~mL})$ was added dropwise. The mixture was allowed to warm to room temperature. $\mathrm{H}_{2} \mathrm{O}(5$ $\mathrm{mL}$ ) was added and the aqueous layer was extracted 3 times with $\mathrm{Et}_{2} \mathrm{O}$. The combined organic layers were dried over $\mathrm{MgSO}_{4}$, filtered, and concentrated under reduced pressure. The mixture was purified with a silica plug using hexanes as eluent, affording $2 d-1 \mathbf{a}$ as a clear liquid (1.248 $\mathrm{g}$, $72 \%$ yield), with $>99 \%$ deuteration.

$\mathrm{R}_{\mathrm{f}}=0.28$ (hexanes)

${ }^{1} \mathrm{H}$ NMR $\left(500 \mathrm{MHz}, \mathrm{CDCl}_{3}\right) \delta 7.65(\mathrm{~d}, J=7.6 \mathrm{~Hz}, 1 \mathrm{H}), 7.57(\mathrm{~d}, J=8.2 \mathrm{~Hz}, 1 \mathrm{H}), 7.35(\mathrm{t}, J=7.7$ $\mathrm{Hz}, 1 \mathrm{H}), 7.29(\mathrm{t}, J=7.4 \mathrm{~Hz}, 1 \mathrm{H}), 6.81(\mathrm{~s}, 1 \mathrm{H})$.

${ }^{2} \mathrm{H}$ NMR $\left(77 \mathrm{MHz}, \mathrm{CDCl}_{3}\right) \delta 7.79$.

${ }^{13} \mathrm{C}$ NMR $\left(126 \mathrm{MHz}, \mathrm{CDCl}_{3}\right) \delta 155.0,144.8(\mathrm{t}, J=61.7 \mathrm{~Hz}, \mathrm{CD}) 127.5,124.3,122.8,121.3$, $111.5,106.5$.

GC-MS (EI) calculated for [M]+ 119.1, found 119.1<smiles>[2H]c1coc2ccccc12</smiles>

\section{Benzo[b]furan-3- $d(3 d-1 \mathbf{a})$ :}

$n$-BuLi (2.5 M in hexanes, $6 \mathrm{mmol}, 2.4 \mathrm{~mL}$ ) was added dropwise with vigorous stirring to a solution containing 3-bromobenzo[b]furan $(6 \mathrm{mmol}, 1.182 \mathrm{~g})$ in THF $(16 \mathrm{~mL})$ at $-98^{\circ} \mathrm{C}$. The reaction was quenched with $\mathrm{MeOH}-d_{4}(2 \mathrm{~mL})$ at $-98^{\circ} \mathrm{C}$ and then allowed to come to room temperature. $\mathrm{D}_{2} \mathrm{O}(6 \mathrm{~mL})$ was added and the organic were removed under reduced pressure. The aqueous solution was extracted 3 times with $\mathrm{Et}_{2} \mathrm{O}$. The combined organic layers were dried over $\mathrm{MgSO}_{4}$, filtered, and concentrated under reduced pressure. The mixture was purified with a silica plug using hexanes as eluent, affording $3 d-1$ a as a clear liquid (476 $\mathrm{mg}, 65 \%$ yield), with $95 \%$ deuteration. ${ }^{16}$

$\mathrm{R}_{\mathrm{f}}=0.32$ (hexanes)

${ }^{1} \mathrm{H}$ NMR $\left(500 \mathrm{MHz}, \mathrm{CDCl}_{3}\right) \delta 7.62(\mathrm{~m}, J=13.4 \mathrm{~Hz}, 2 \mathrm{H}), 7.52(\mathrm{~d}, J=8.8 \mathrm{~Hz}, 1 \mathrm{H}), 7.31(\mathrm{t}, J=$ $8.3 \mathrm{~Hz}, 1 \mathrm{H}), 7.27-7.22(\mathrm{~m}, 1 \mathrm{H})$.

${ }^{2} \mathrm{H}$ NMR $\left(77 \mathrm{MHz}, \mathrm{CDCl}_{3}\right) \delta 6.87(\mathrm{~s}, 1 \mathrm{H})$.

${ }^{13} \mathrm{C}$ NMR $\left(126 \mathrm{MHz}, \mathrm{CDCl}_{3}\right) \delta 155.2,145.0,127.5,124.4,122.9,121.3,111.5,106.5(\mathrm{t}, J=$ $52.9 \mathrm{~Hz}, \mathrm{CD})$.

GC-MS (EI) calculated for [M]+ 119.1, found 119.1 


\section{$\underline{\text { V. Heteroatom Comparison }}$}

Table S1. Comparison of different heterobiaryls ${ }^{\mathrm{a}}$

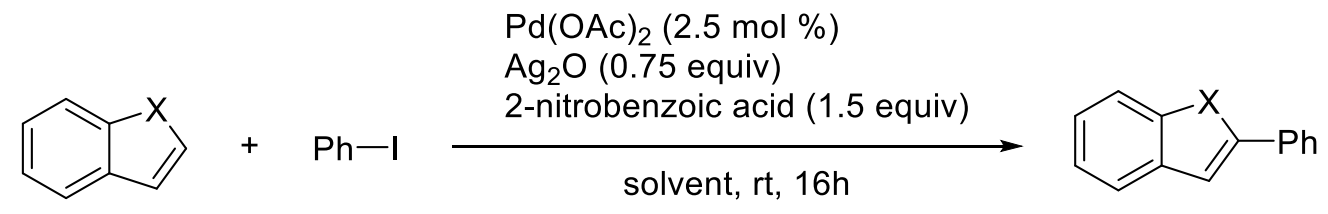

\begin{tabular}{ccccc} 
Entry & X & DMF (\%) & HFIP (\%) & C2:C3 \\
\hline 1 & $\mathrm{~N}$ & 90 & 44 & $>99: 1$ \\
2 & $\mathrm{O}$ & 0 & 90 & $>99: 1$ \\
3 & $\mathrm{~S}$ & 0 & 71 & $1:>99$
\end{tabular}

${ }^{\text {a}}$ Yield determined by ${ }^{1} \mathrm{H}$ NMR using ethylene carbonate as an internal standard. Run using the general procedure.

Table S2. Evaluation of heteroaryl iodides ${ }^{\mathrm{a}}$

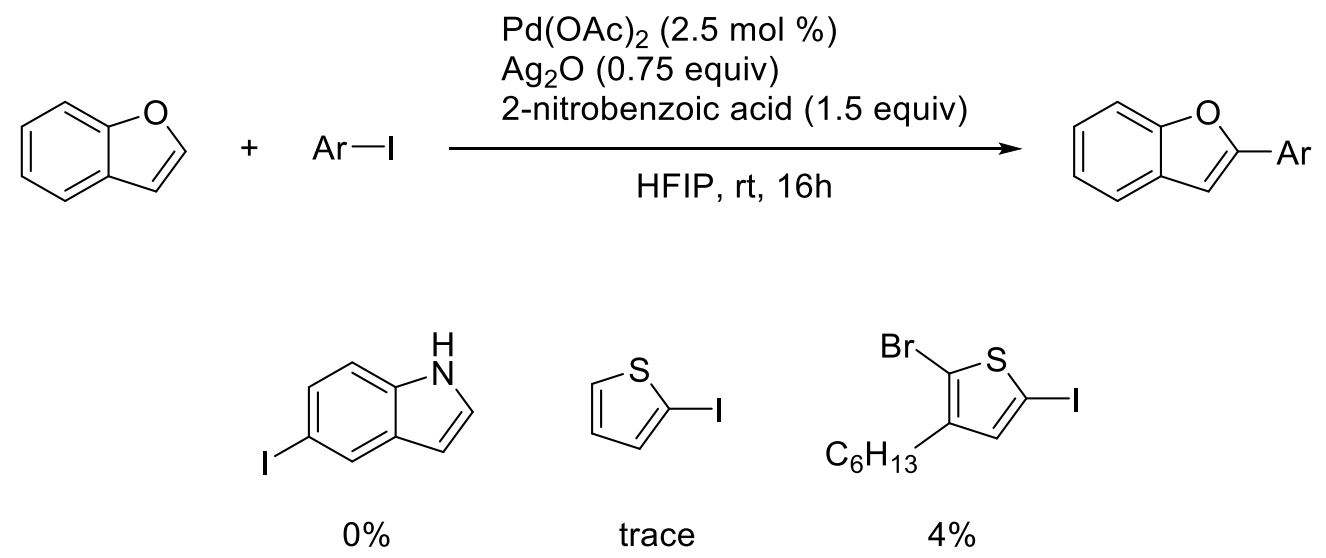

${ }^{\text {a}}$ Yield determined by ${ }^{1} \mathrm{H}$ NMR using ethylene carbonate as an internal standard. Run using the general procedure.

As outlined in Table S2, investigations into the utilization of heteroaryl iodides using the optimized methodology did not provide the intended products in meaningful quantities. This is expected in light of the results in Table S1, as the specific hetereoaryl iodides investigated have $\mathrm{C}-\mathrm{H}$ bonds that are reactive under these conditions, leading to competing regioselectivity and a complex mixture of products. 


\section{Mechanistic Experiments: \\ Deuterium Exchange:}

To an oven-dried vial and stir bar was added $\mathrm{Pd}(\mathrm{OAc})_{2}(2.5 \mathrm{~mol} \%, 0.005 \mathrm{mmol}, 1.12 \mathrm{mg}), \mathrm{Ag}_{2} \mathrm{O}$ ( 0.75 equiv, $0.15 \mathrm{mmol}, 34.8 \mathrm{mg}$ ), 2-nitrobenzoic acid (1.5 equiv, $0.3 \mathrm{mmol}, 50.7 \mathrm{mg}$ ). The vial was evacuated and backfilled with $\mathrm{N}_{2}$ three times. Hexafluoro-2-propanol was added (1 M, 0.2 $\mathrm{mL}$ ), followed by $2 d-\mathbf{1 a}$ or $3 d-\mathbf{1 a}$ (1 equiv, $0.2 \mathrm{mmol}, 24 \mathrm{mg}$ ) and, 2a if using ( 2 equiv, $0.4 \mathrm{mmol}$, $45 \mu \mathrm{L})$. The reaction was allowed to stir at room temperature $\left(22{ }^{\circ} \mathrm{C}\right)$ for $3 \mathrm{~h}$. After this time, the reaction mixture was filtered through a silica plug using $\mathrm{CH}_{2} \mathrm{Cl}_{2}$ to transfer and subsequently concentrated under reduced pressure. Deuterium scrambling was calculated using ${ }^{1} \mathrm{H}$ NMR in $\mathrm{CDCl}_{3}$ using 1,3-dinitrobenzene as an internal standard.

\section{KIE:}

General Considerations:

Experiments for the deuterated and non-deuterated substrates were done simultaneously utilizing the same catalyst stock solution. The 2-deuterobenzofuran and benzofuran experiments were done in one set of reactions, and the 3-deuterobenzofuran and an additional set of benzofuran experiments were determined in a separate block of experiments. The rate constant for each substrate is determined from the average of four sets of trials for C-2 and three sets of trials for C3.

Stock solutions:

A stock solution was prepared for the catalyst. In an oven dried vial with stir bar was added $\mathrm{Pd}(\mathrm{OAc})_{2}(39.2 \mathrm{mg})$ and cooled under vacuum. After three $\mathrm{N}_{2} /$ vacuum cycles, $3.5 \mathrm{~mL} \mathrm{HFIP}$ was added.

A stock solution was prepared for the substrates. In an oven dried vial with stir bar, which was cooled under vacuum, was added the appropriate benzofuran (non-deuterated: $413 \mathrm{mg}$, deuterated: $416 \mathrm{mg})$, iodobenzene (1428 mg), and $1.75 \mathrm{~mL}$ HFIP.

Reaction set-up:

To an oven-dried vial with stir bar was added $\mathrm{Ag}_{2} \mathrm{O}$ (173.3 $\mathrm{mg}, 0.75$ equiv), 2-nitrobenzoic acid (250.7 mg, $1.5 \mathrm{eq}$ ), and 1,3-dinitrobenzene ( 0.5 equiv) as an internal standard and cooled under vacuum. The vial was cycled through $\mathrm{N}_{2} /$ vacuum three times before $0.5 \mathrm{~mL}$ of the catalyst solution and $0.8 \mathrm{~mL}$ of the substrate solution were added simultaneously to start the reaction. At the appropriate times, $100 \mu \mathrm{L}$ aliquots were taken, filtered through $\mathrm{SiO}_{2}$ using $\mathrm{CH}_{2} \mathrm{Cl}_{2}$ and subsequently concentrated under reduced pressure. The solution was analyzed using ${ }^{1} \mathrm{H}$ NMR in $\mathrm{CDCl}_{3}$ using 1,3-dinitrobenzene as an internal standard.

Results:

\begin{tabular}{|l|l|}
\hline $\mathbf{k}_{\mathbf{h}}$ & 0.1451 \\
\hline $\mathbf{k}_{\mathbf{d}}[2 d-1 \mathrm{a}]$ & 0.1267 \\
\hline $\mathrm{KIE}\left(\mathrm{k}_{\mathbf{h}} / \mathbf{k}_{\mathbf{d}}\right)$ & 1.14522 \\
\hline
\end{tabular}




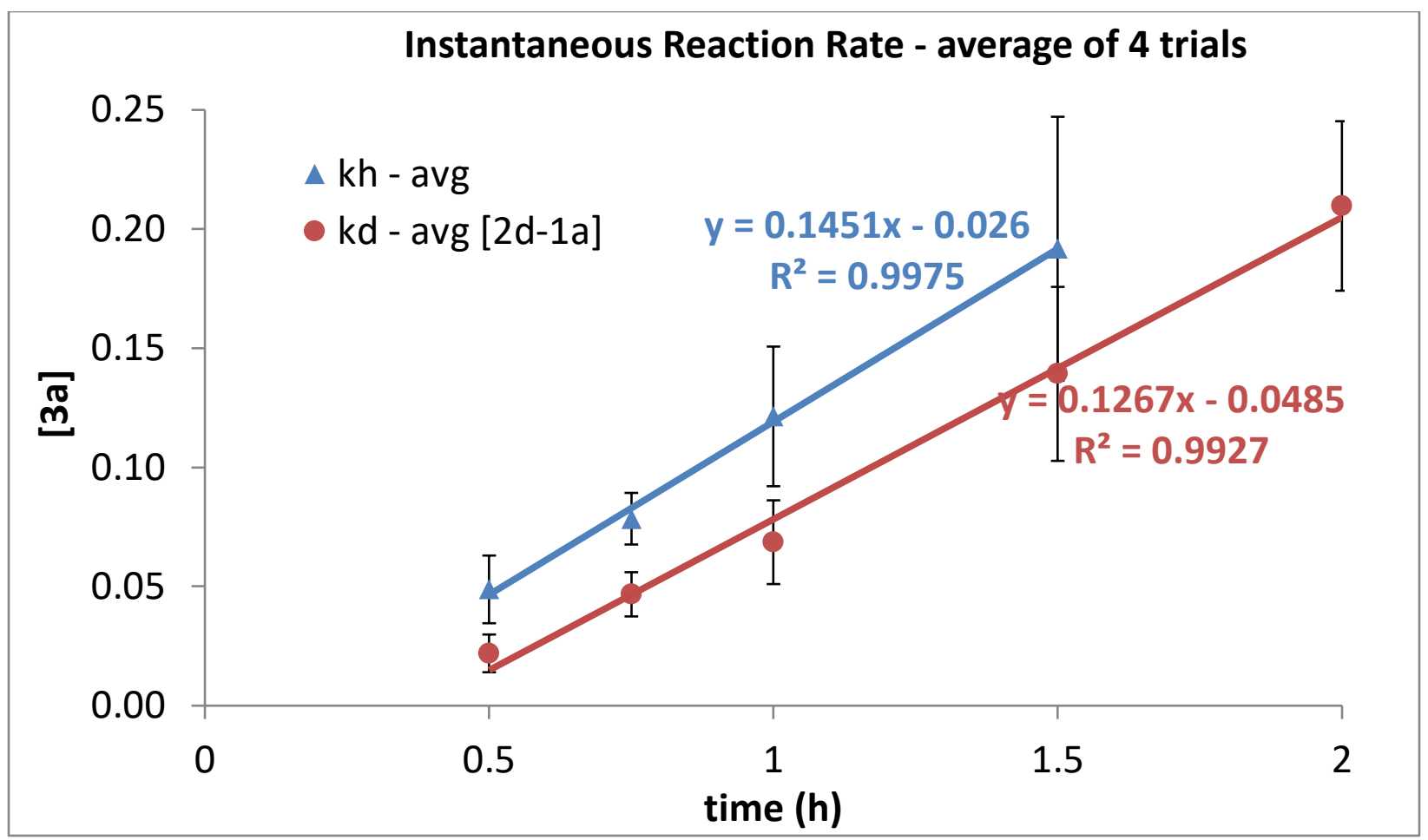

Figure S1. Instantaneous reaction rate determination for $1 \mathbf{a}$ and $2 d-1 \mathbf{a}$ 

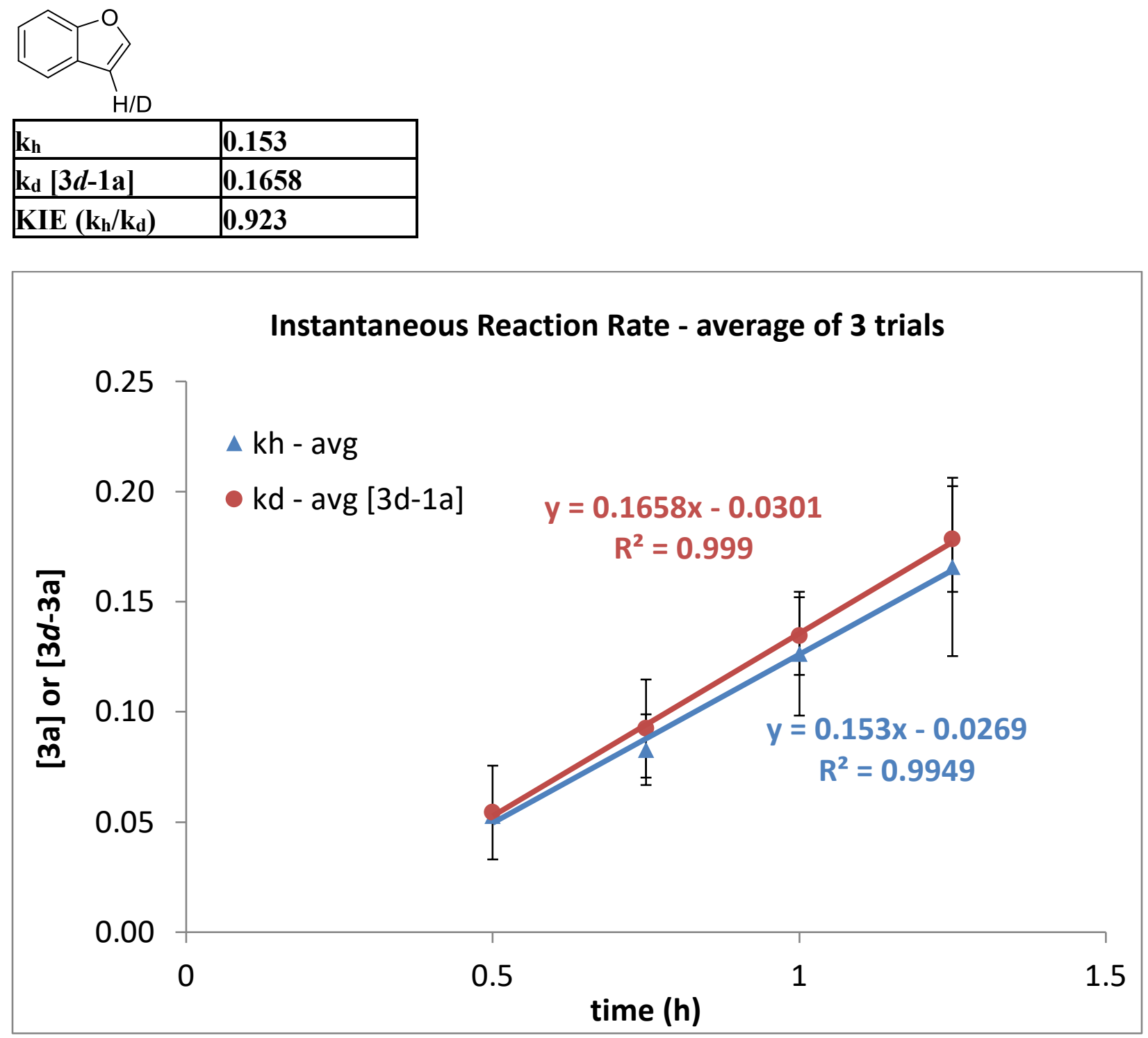

Figure S2. Instantaneous reaction rate determination for $\mathbf{1 a}$ and $3 d-\mathbf{1 a}$

Considering the KIE data reported herein, significant error is included in the analysis arising from variations between replicates. While this is exacerbated by the relatively small differences being analyzed, is an inherent challenge with instantaneous reaction rate analysis exacerbated by the heterogeneity of the reaction mixture. Regardless, the results have still been included as the overall trends for both the KIE values at C-2 and C-3 were replicated many times over and provide reliable insight as a trend although future studies are needed for greater accuracy and precision. While both KIE values are indicative of Heck-type arylation, due to the small differences between $\mathrm{k}_{\mathrm{h}}$ and $\mathrm{k}_{\mathrm{d}}$ and the relatively large error accompanying the likelihood that an $\mathrm{S}_{\mathrm{E}} \mathrm{Ar}$ pathway may not demonstrate any KIE value, these KIE values aren't able to differentiate between Heck-type and $\mathrm{S}_{\mathrm{E}}$ Ar pathways with confidence. 
VIII. Oxvarylation Mechansim:

Scheme S1. Proposed oxyarylation mechanism for the formation of dihydrofuran product 4 (top) and contrasting $S_{E} A r$ mechanism (bottom)

Heck-type

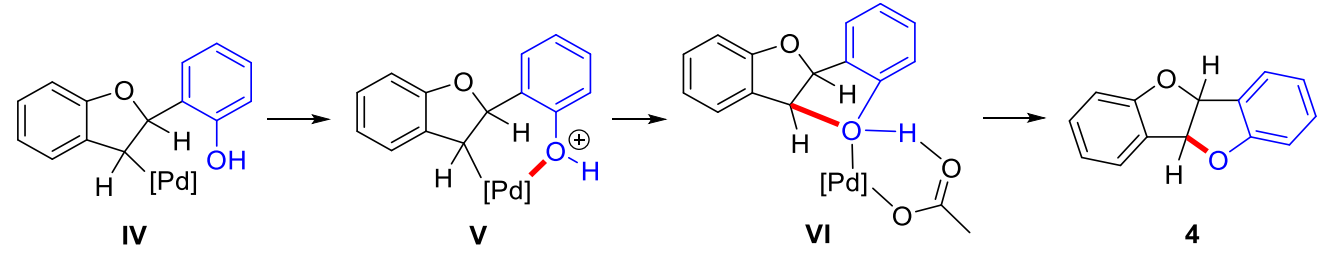

$\mathrm{S}_{\mathrm{E}} \mathrm{Ar}$ at C-2

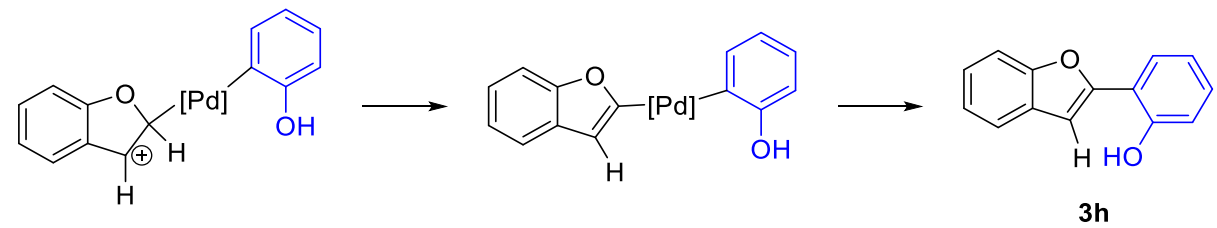




\section{References:}

(1) Cao, J.; Chen, Z. L.; Li, S. M.; Zhu, G. F.; Yang, Y. Y.; Wang, C.; Chen, W. Z.; Wang, J. T.; Zhang, J. Q.; Tang, L. Palladium-Catalyzed Regioselective C-2 Arylation of

Benzofurans with N'-Acyl Arylhydrazines. European J. Org. Chem. 2018, No. 22, 2774 2779.

(2) Qin, D. D.; Chen, W.; Tang, X.; Yu, W.; Wu, A. A.; Liao, Y.; Chen, H. Bin. Accessing 2Arylbenzofurans by CuI2(Pip)2-Catalyzed Tandem Coupling/Cyclization Reaction:

Mechanistic Studies and Application to the Synthesis of Stemofuran A and Moracin M. Asian J. Org. Chem. 2016, 5 (11), 1345-1352.

(3) Yin, S. C.; Zhou, Q.; Zhao, X. Y.; Shao, L. X. N-Heterocyclic Carbene-Palladium(II)-1Methylimidazole Complex Catalyzed Direct C-H Bond Arylation of Benzo[b]Furans with Aryl Chlorides. J. Org. Chem. 2015, 80 (17), 8916-8921.

(4) Baxendale, I. R.; Griffiths-Jones, C. M.; Ley, S. V.; Tranmer, G. K. Microwave-Assisted Suzuki Coupling Reactions with an Encapsulated Palladium Catalyst for Batch and Continuous-Flow Transformations. Chem. - A Eur. J. 2006, 12 (16), 4407-4416.

(5) Imrich, H. G.; Conrad, J.; Beifuss, U. Copper-Catalyzed Double Intramolecular Ullmann Coupling for the Synthesis of Diastereomerically and Enantiomerically Pure 4b,9bDihydrobenzofuro[3,2-b]Benzofurans. European J. Org. Chem. 2015, 2015 (35), 77187734.

(6) Chakrabarty, I.; Akram, M. O.; Biswas, S.; Patil, N. T. Visible Light Mediated

Desilylative C(Sp2)-C(Sp2) Cross-Coupling Reactions of Arylsilanes with Aryldiazonium Salts under Au(i)/Au(Iii) Catalysis. Chem. Commun. 2018, 54 (52), 7223-7226.

(7) Dao-Huy, T.; Haider, M.; Glatz, F.; Schnürch, M.; Mihovilovic, M. D. Direct Arylation of Benzo[b]Furan and Other Benzo-Fused Heterocycles. European J. Org. Chem. 2014, No. 36, 8119-8125.

(8) Wang, Z.; Li, Y.; Yan, B.; Huang, M.; Wu, Y. Palladium-Catalyzed Phosphine-Free Direct C-H Arylation of Benzothiophenes and Benzofurans Involving MIDA Boronates. Synlett 2015, 26 (4), 531-536.

(9) Ranjbari, M. A.; Tavakol, H. Catalyst-Free Synthesis of Benzofuran Derivatives from Cascade Reactions between Nitroepoxides and Salicylaldehydes. J. Org. Chem. 2021, 86 (6), 4756-4762.

(10) Henry, M. C.; Sutherland, A. Synthesis of Benzo[ b]Furans by Intramolecular C-O Bond Formation Using Iron and Copper Catalysis. Org. Lett. 2020, 22 (7), 2766-2770.

(11) Shin, T.; Kim, M.; Jung, Y.; Cho, S. J.; Kim, H.; Song, H. Characterization of Heterogeneous Aryl-Pd(Ii)-Oxo Clusters as Active Species for C-H Arylation. Chem. Commun. 2020, 56 (92), 14404-14407.

(12) Li, H.; Roisnel, T.; Soulé, J. F.; Doucet, H. Regiocontrolled Palladium-Catalyzed Direct C2-Arylations of Methoxalen Using Benzenesulfonyl Chlorides and C2,C3-Diarylations 
Using Aryl Bromides as the Aryl Sources. Tetrahedron Lett. 2020, 61 (1).

(13) Ma, W.; Huang, J.; Huang, X.; Meng, S.; Yang, Z.; Li, C.; Wang, Y.; Qi, T.; Li, B. Direct Construction of 2,3-Unsubstituted Benzofurans and Benzothiophenes: Via a Metal-Free Catalyzed Intramolecular Friedel-Crafts Reaction. Org. Chem. Front. 2019, 6 (4), 493497.

(14) Reddy, A. C. S.; Ramachandran, K.; Reddy, P. M.; Anbarasan, P. Rhodium-Catalyzed Sommelet-Hauser Type Rearrangement of $\alpha$-Diazoimines: Synthesis of Functionalized Enamides. Chem. Commun. 2020, 56 (42), 5649-5652.

(15) Pu, X.; Zhang, M.; Lan, J.; Chen, S.; Liu, Z.; Liang, W.; Yang, Y.; Zhang, M.; You, J. Tandem Rh(III)-Catalyzed C-H Heteroarylation of Indolyl Ketones and $\mathrm{Cu}(\mathrm{II})$-Promoted Intramolecular Cyclization: One-Pot Access to Blue-Emitting Phenanthrone-Type Polyheterocycles. Org. Lett. 2019, 21 (4), 1139-1143.

(16) Baciocchi, E.; Sebastiani, G. V. Kinetic Study of the Base-Induced Anti and Syn Eliminations from 2,3-Dihalogeno-2,3-Dihydrobenzofurans in Different Base-Solvent Systems. J. Org. Chem 1979, 44 (1). 


\section{IX. ${ }^{1} \mathrm{H}$ NMR and ${ }^{13} \mathrm{C}$ NMR Spectra}

${ }^{1} \mathrm{H}$ NMR $\left(500 \mathrm{MHz}, \mathrm{CDCl}_{3}\right)$

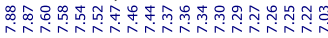
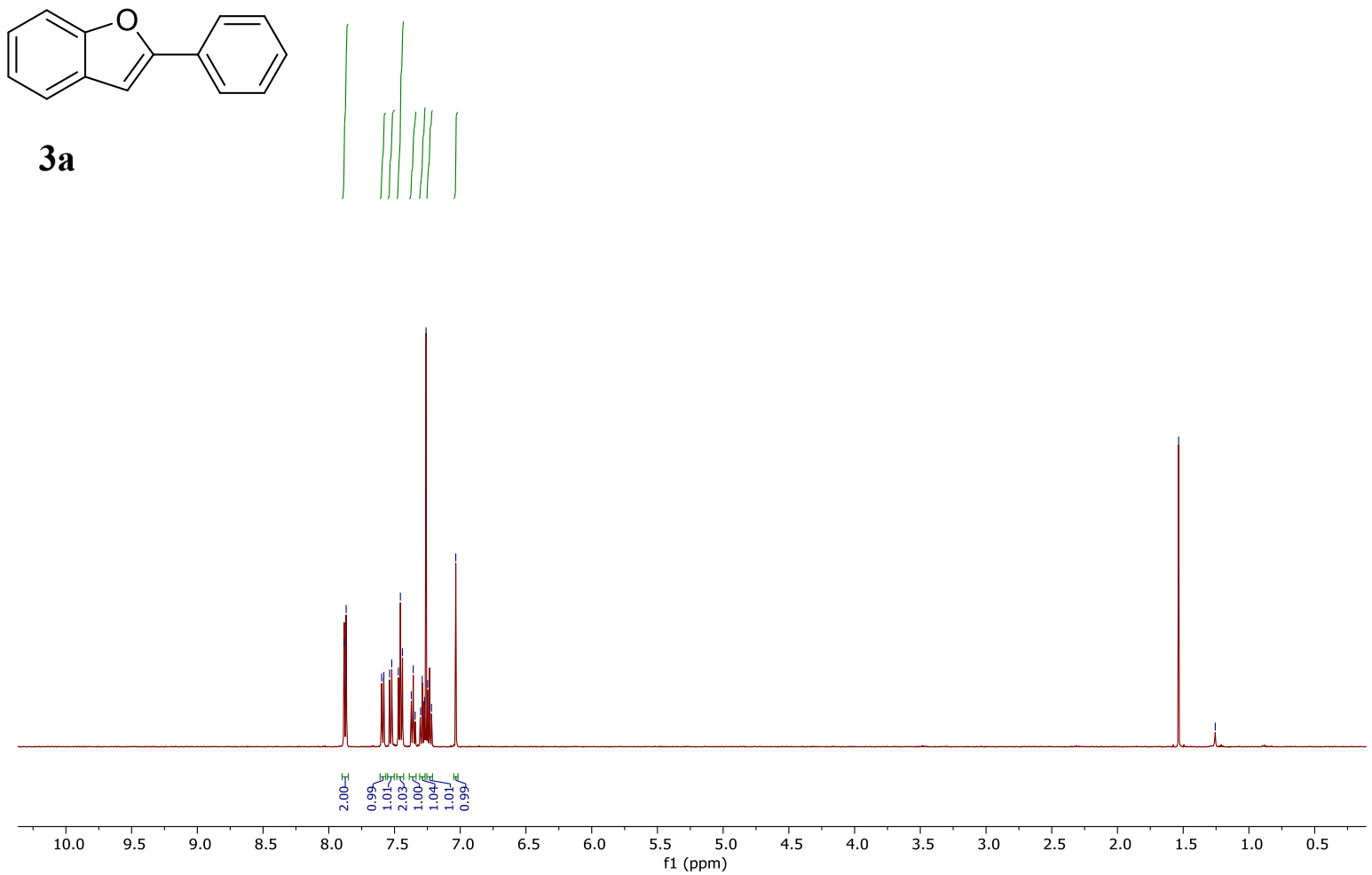

${ }^{13} \mathrm{C}$ NMR (126 MHz, $\left.\mathrm{CDCl}_{3}\right)$

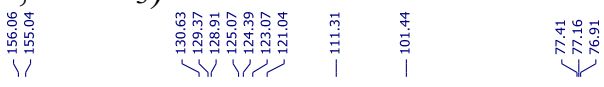

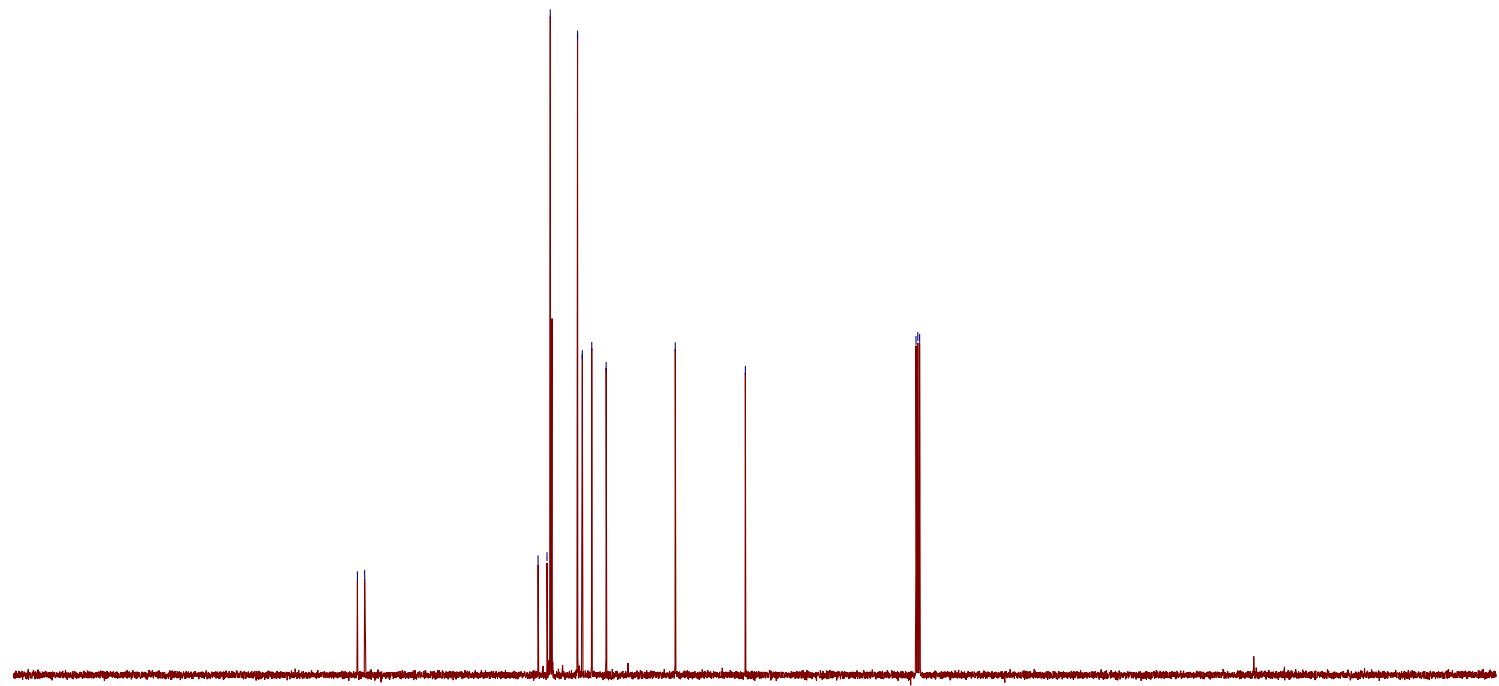

$200 \quad 190$

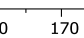

$\begin{array}{lllll}160 & 150 & 140 & 130 & 120\end{array}$ 
${ }^{1} \mathrm{H}$ NMR (500 MHz, CDCl3)
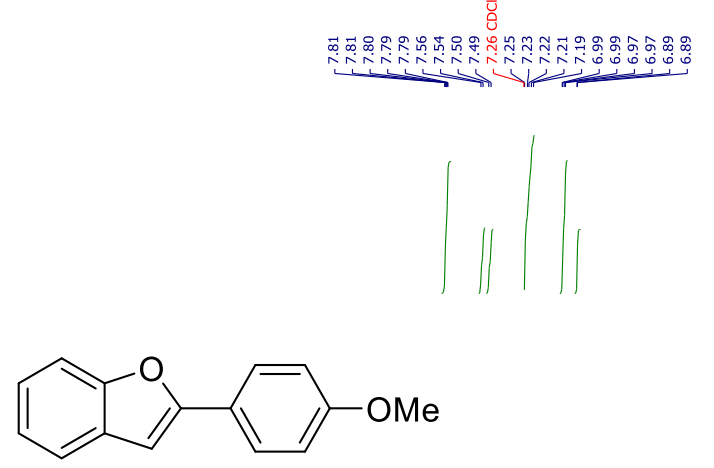

3b

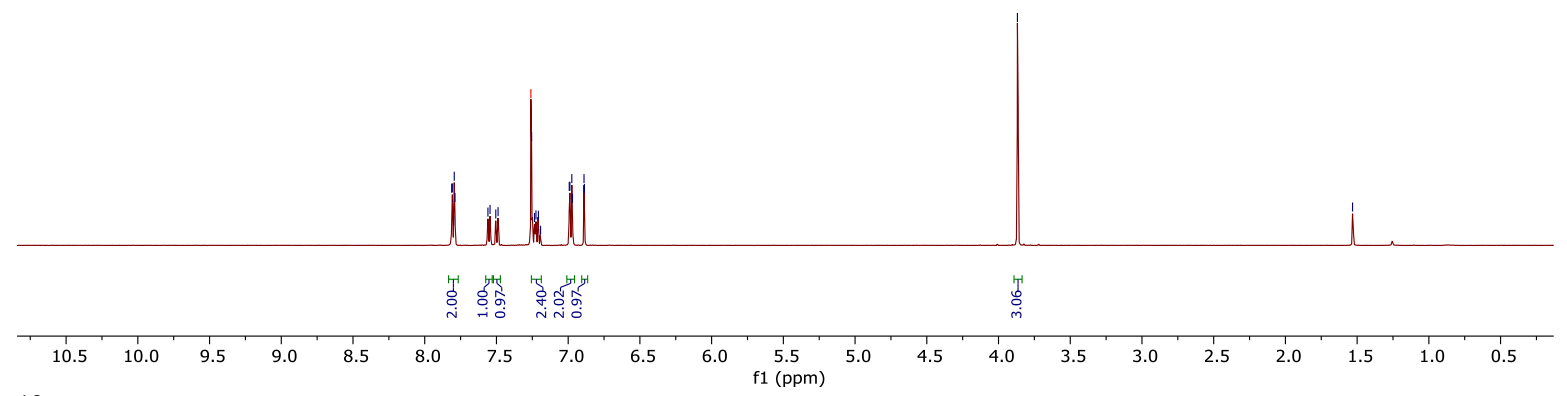

$\left.{ }^{13} \mathrm{C} \mathrm{NMR} \mathrm{(126} \mathrm{MHz,} \mathrm{CDCl}_{3}\right)$

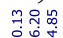

影喝

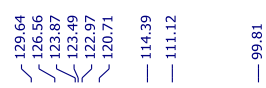

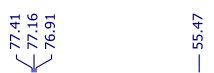

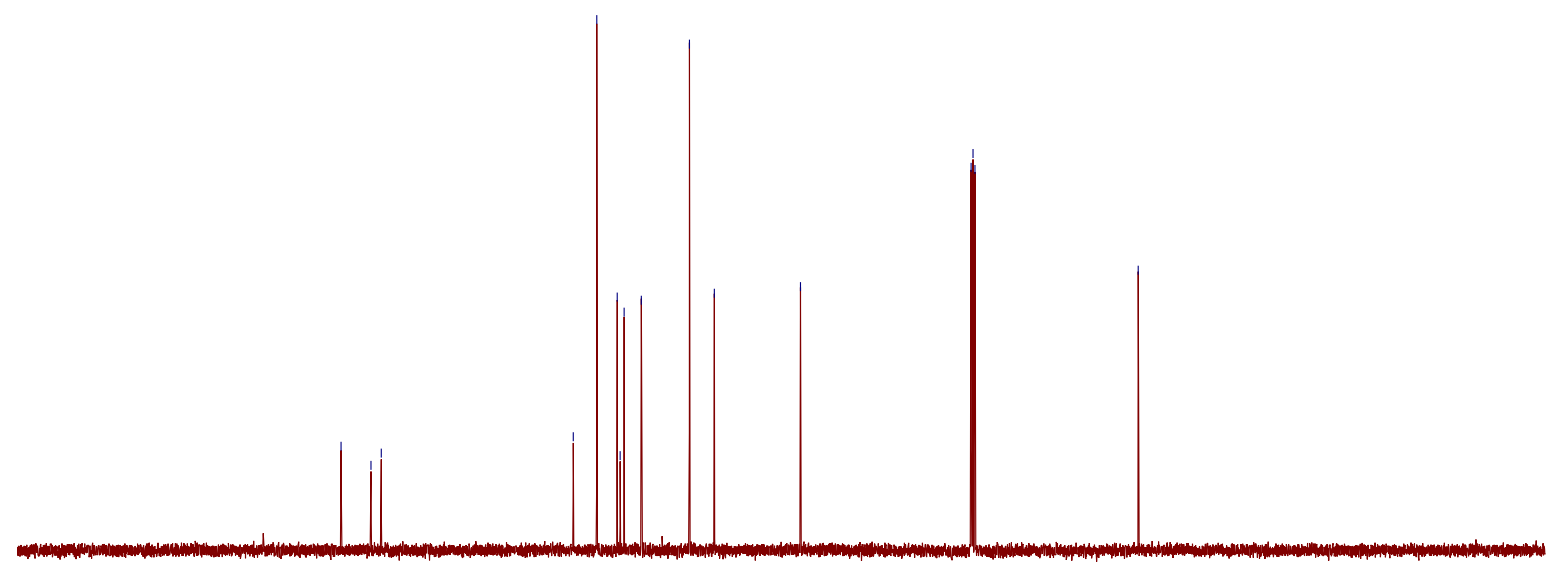

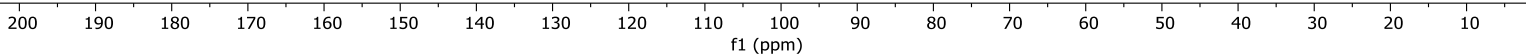


${ }^{1} \mathrm{H} \mathrm{NMR}\left(300 \mathrm{MHz}, \mathrm{CDCl}_{3}\right)$
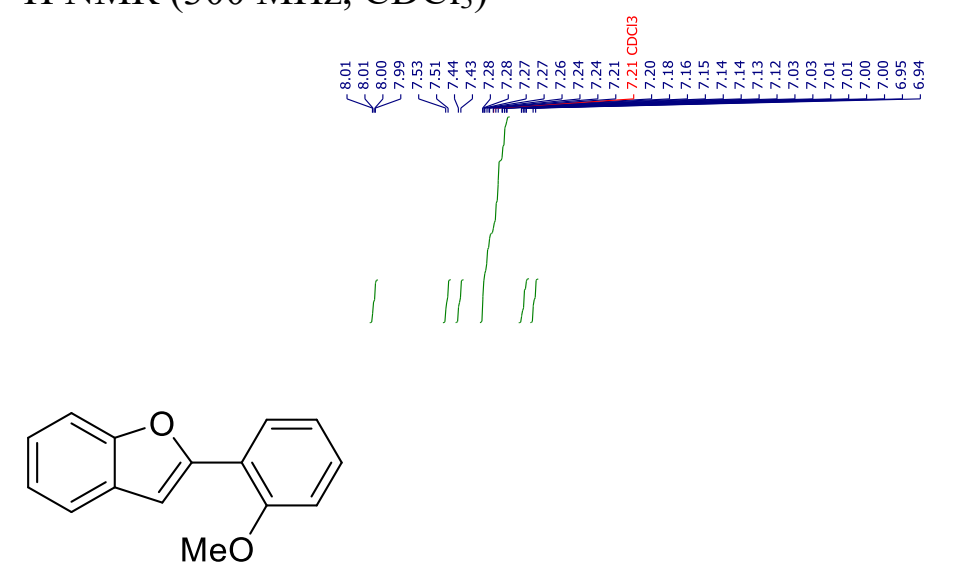

$3 c$

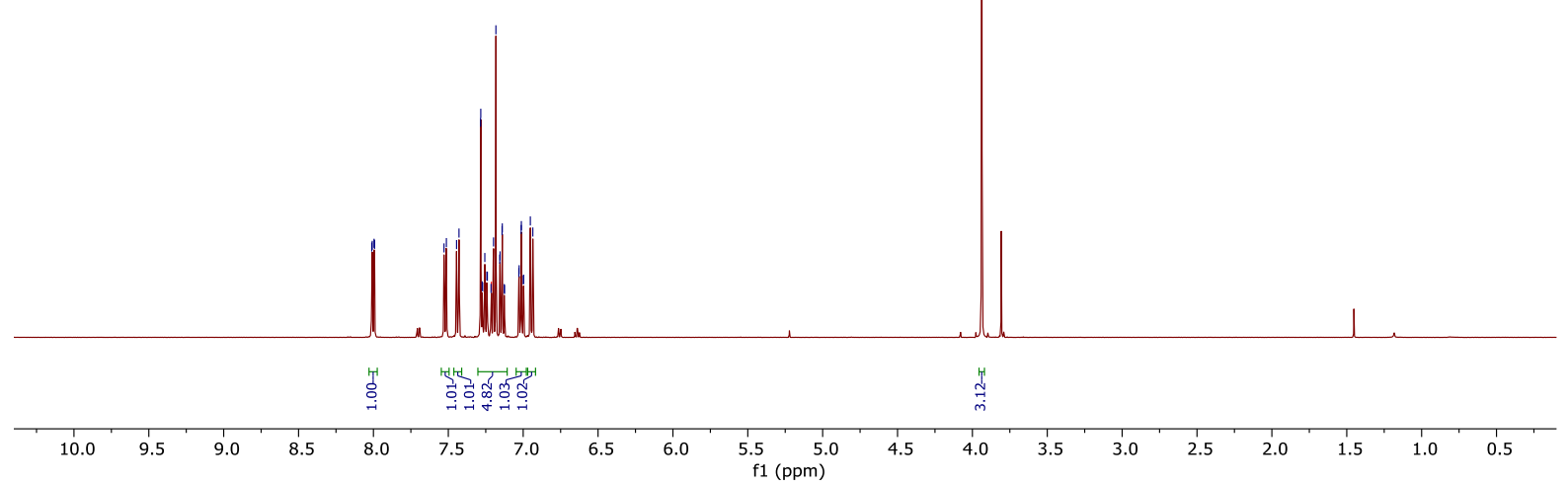

$\left.{ }^{13} \mathrm{C} \mathrm{NMR} \mathrm{(126} \mathrm{MHz,} \mathrm{CDCl}_{3}\right)$

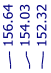

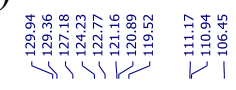
诲

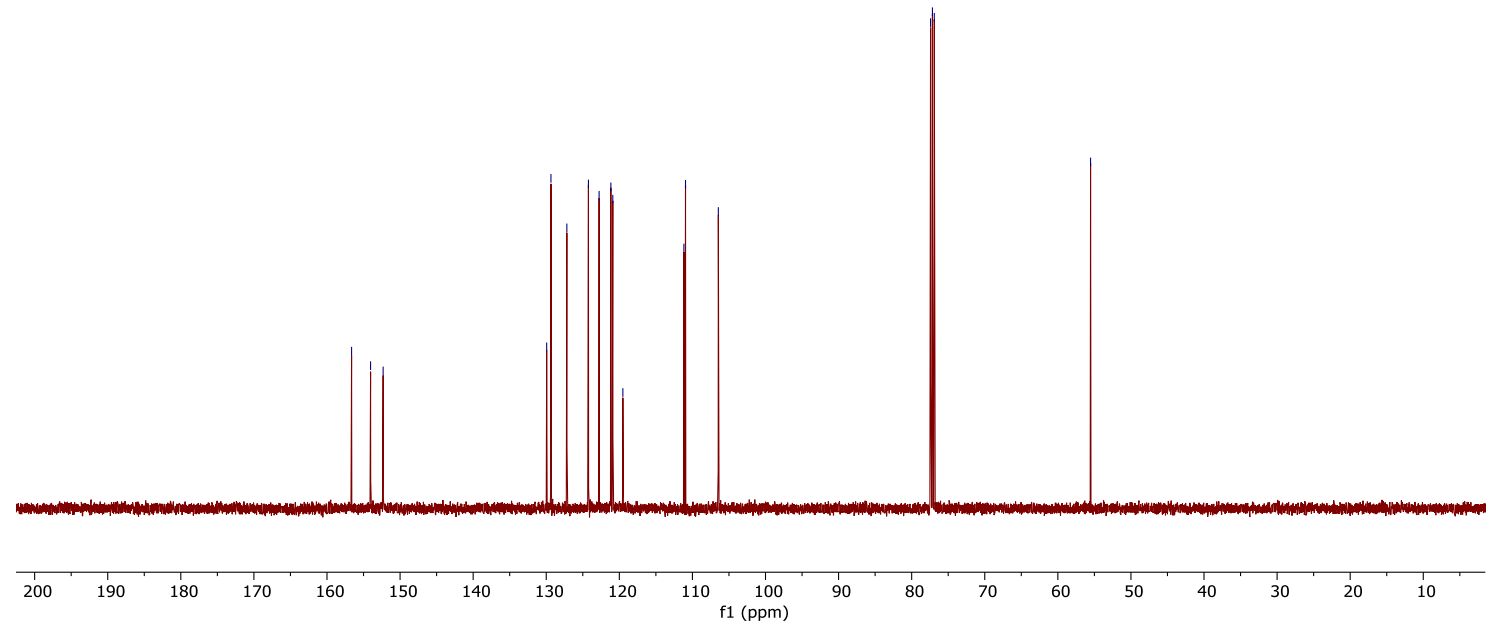




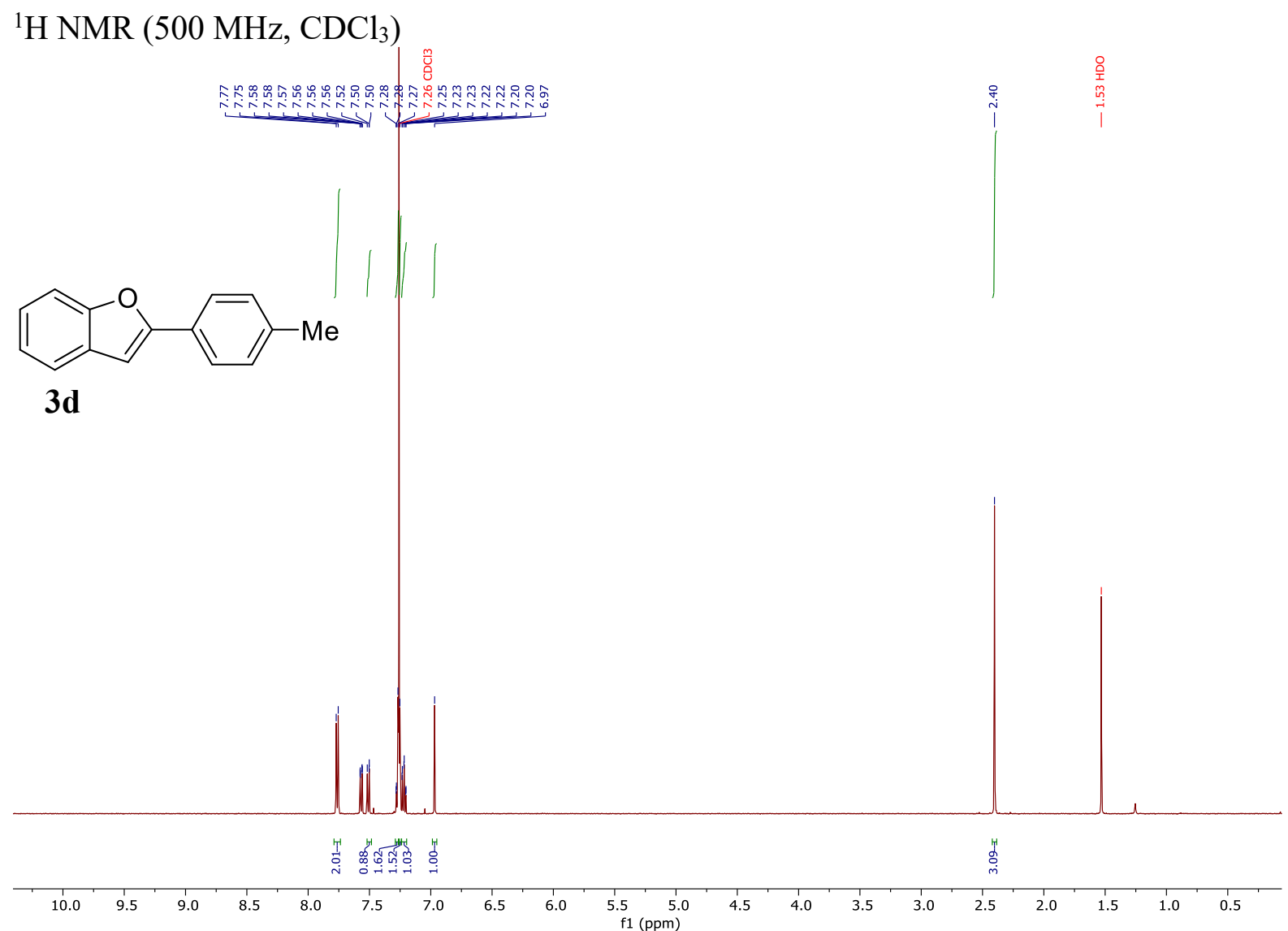

${ }^{13} \mathrm{C}$ NMR (126 MHz, $\left.\mathrm{CDCl}_{3}\right)$

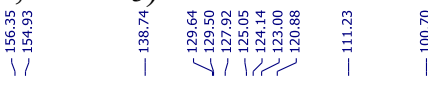

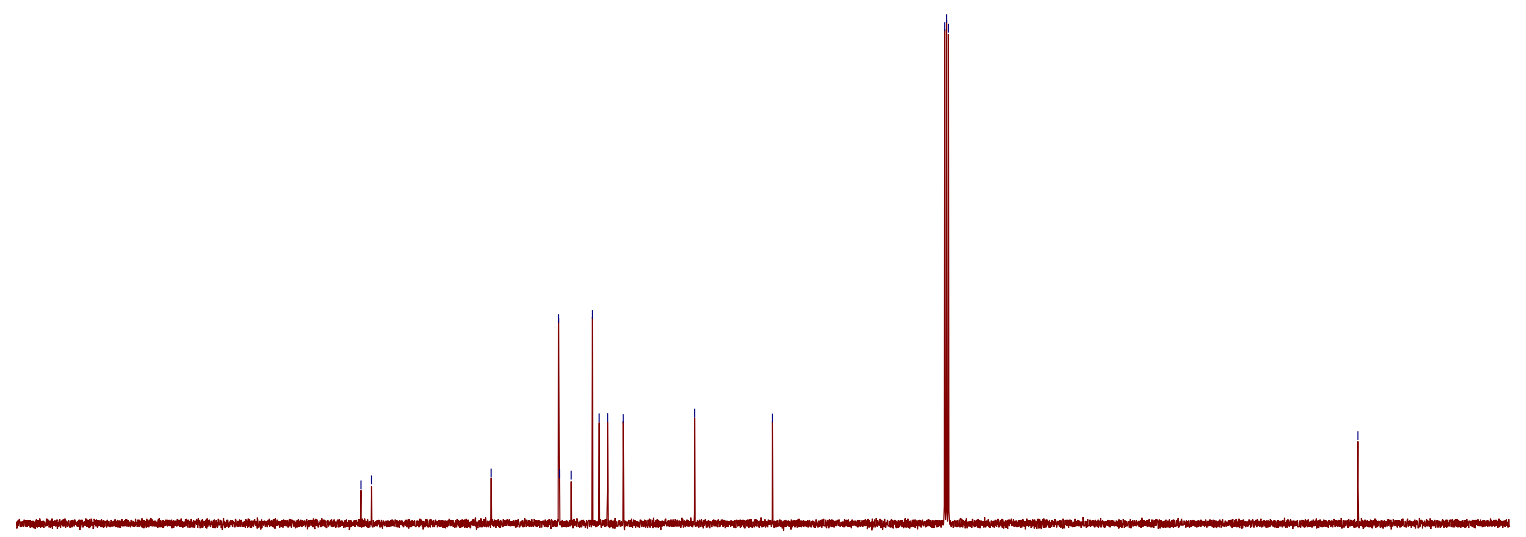

$\begin{array}{rlllllllll}200 & 190 & 180 & 170 & 160 & 150 & 140 & 130 & 120 & 110 \\ \mathrm{f} 1(\mathrm{ppm})\end{array}$ 


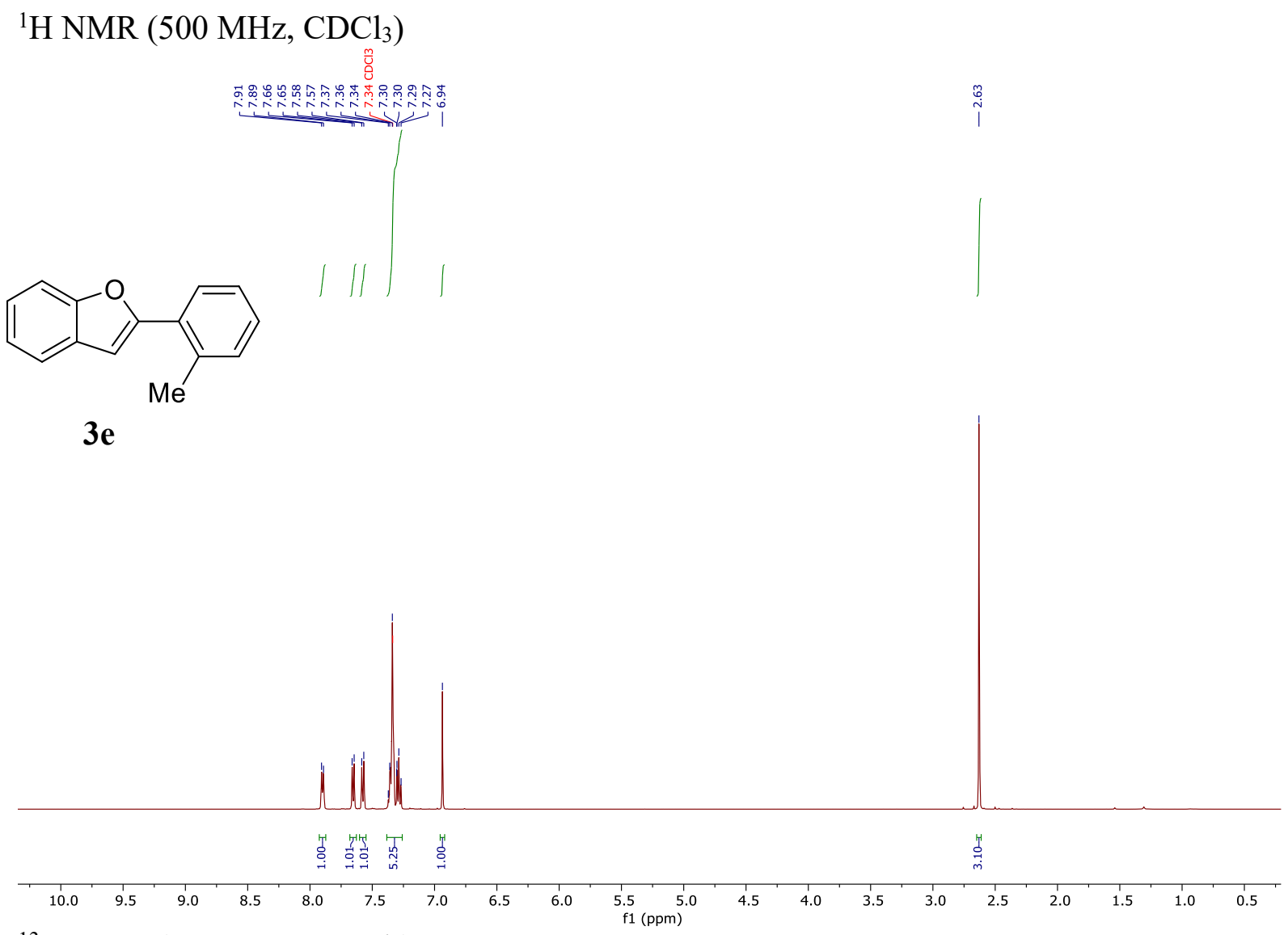

${ }^{13} \mathrm{C}$ NMR (126 MHz, $\left.\mathrm{CDCl}_{3}\right)$

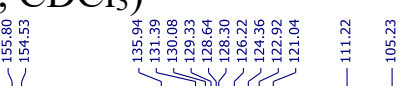

婇

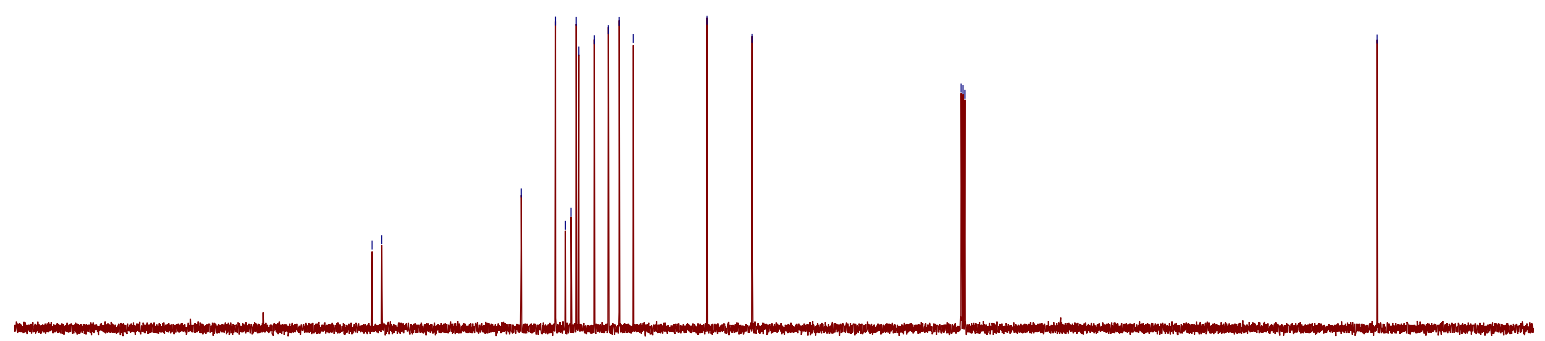

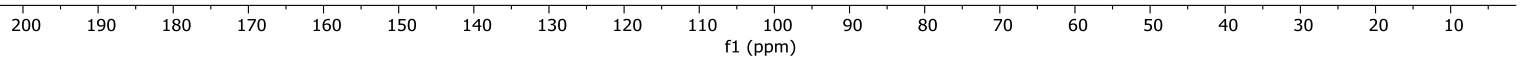


${ }^{1} \mathrm{H}$ NMR (500 MHz, DMSO-d6)

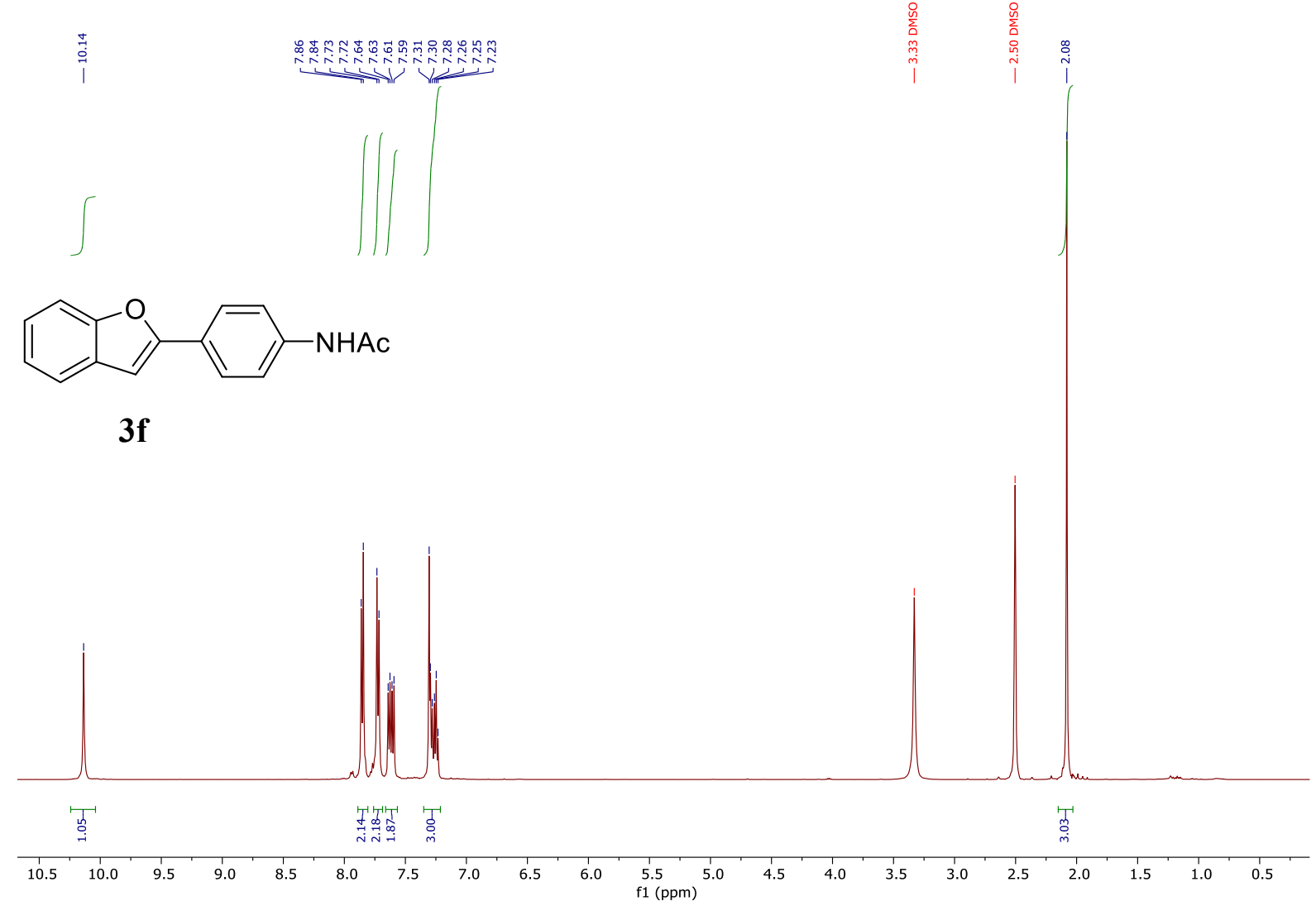

${ }^{13} \mathrm{C}$ NMR (126 MHz, DMSO)
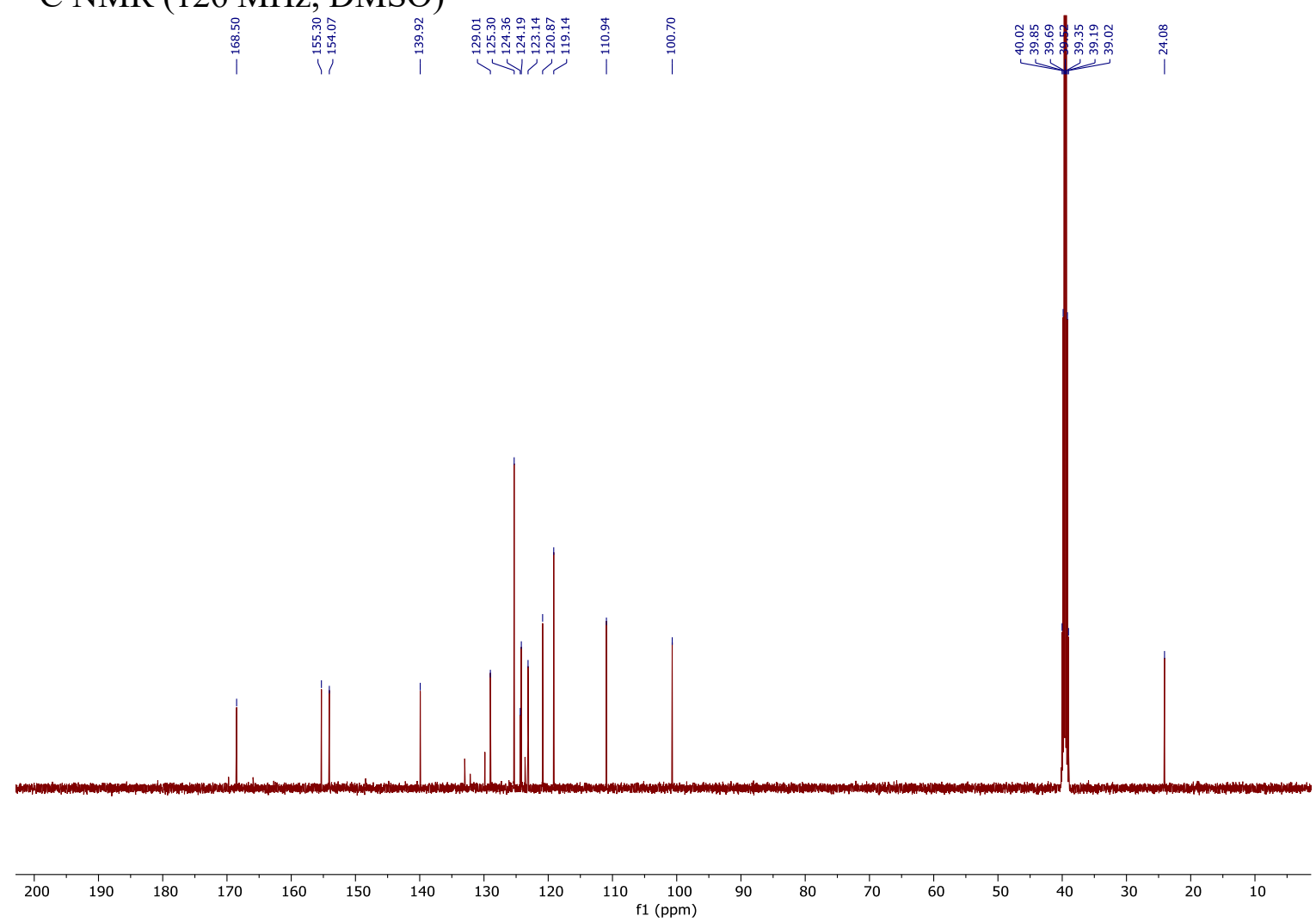


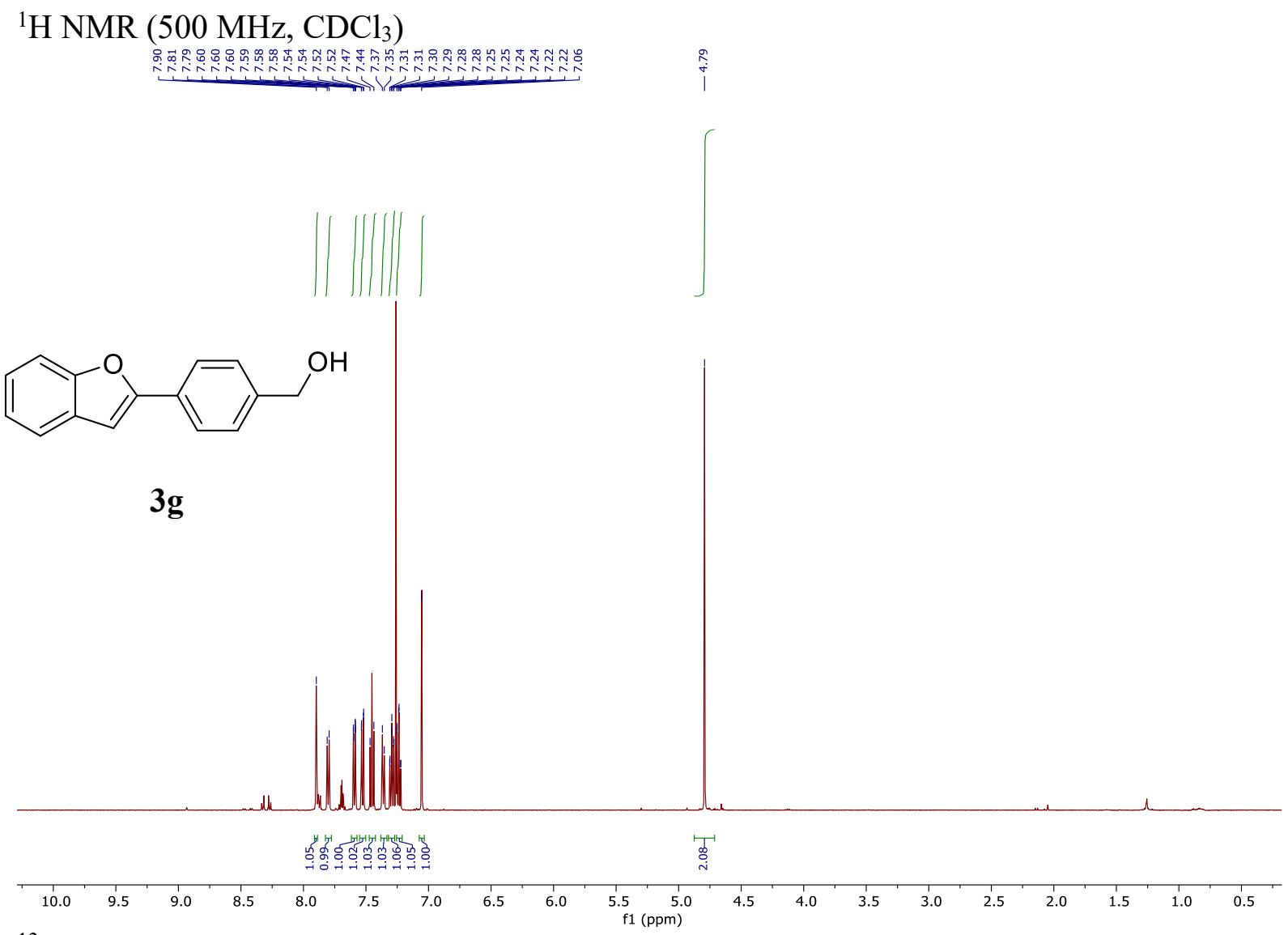

$\left.{ }^{13} \mathrm{C} \mathrm{NMR} \mathrm{(126} \mathrm{MHz,} \mathrm{CDCl}_{3}\right)$

|l

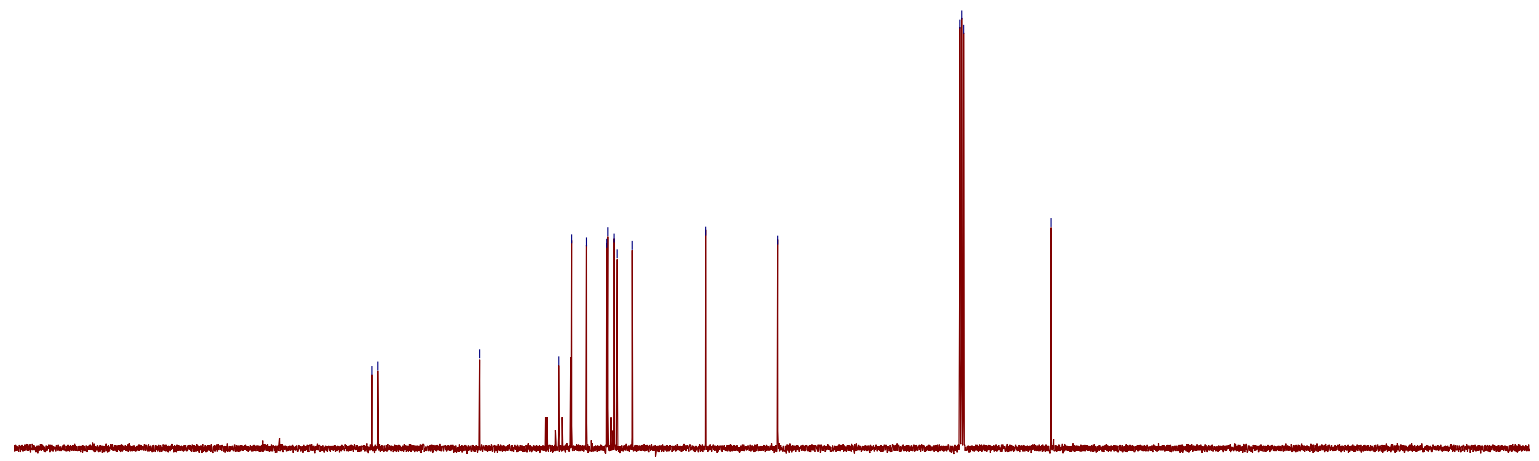

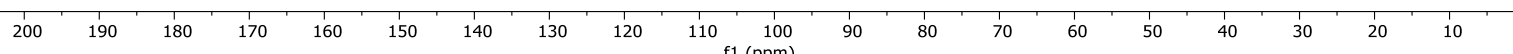


${ }^{1} \mathrm{H} \mathrm{NMR}\left(500 \mathrm{MHz}, \mathrm{CDCl}_{3}\right)$
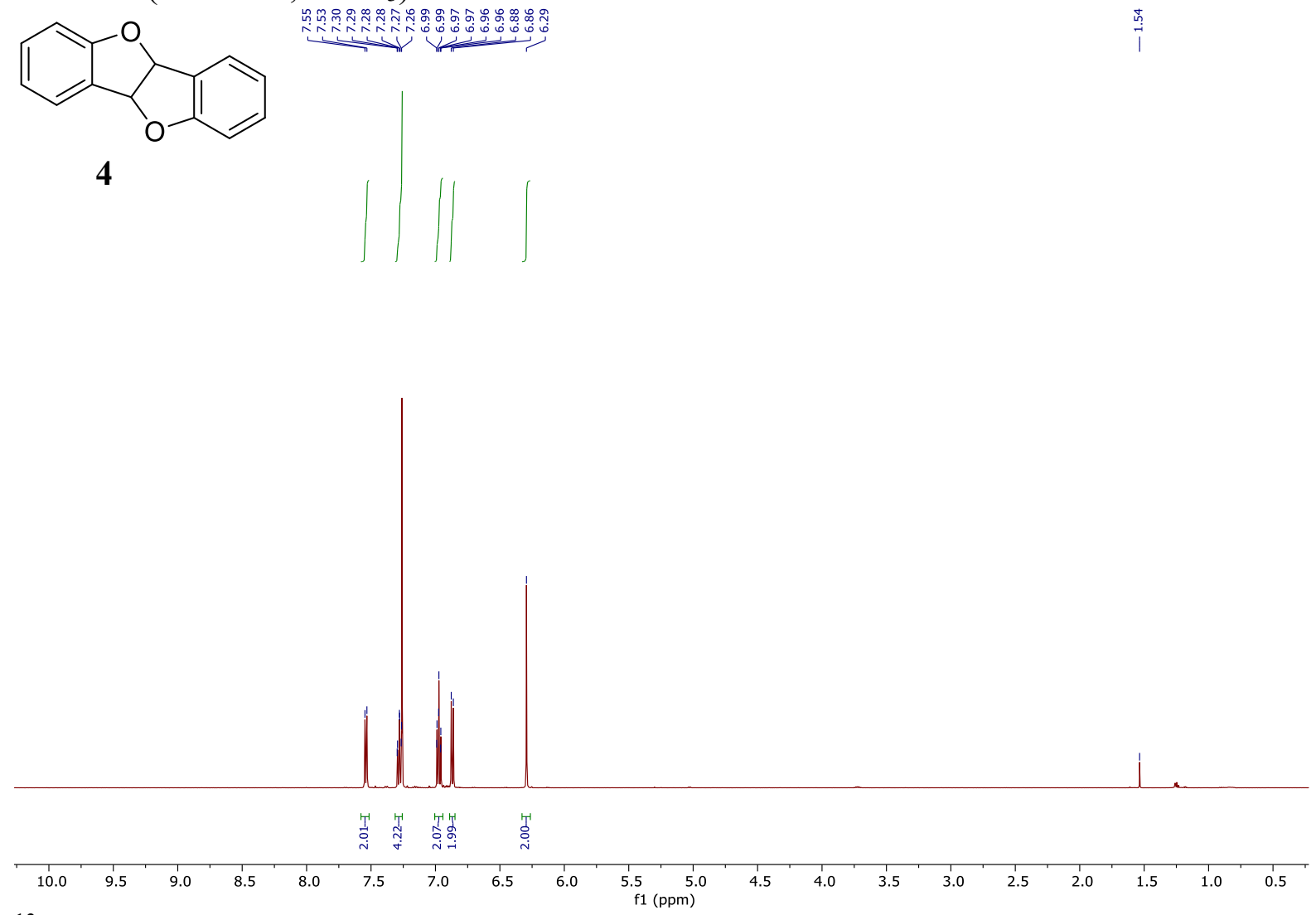

$\left.{ }^{13} \mathrm{C} \mathrm{NMR} \mathrm{(126} \mathrm{MHz,} \mathrm{CDCl}_{3}\right)$

1

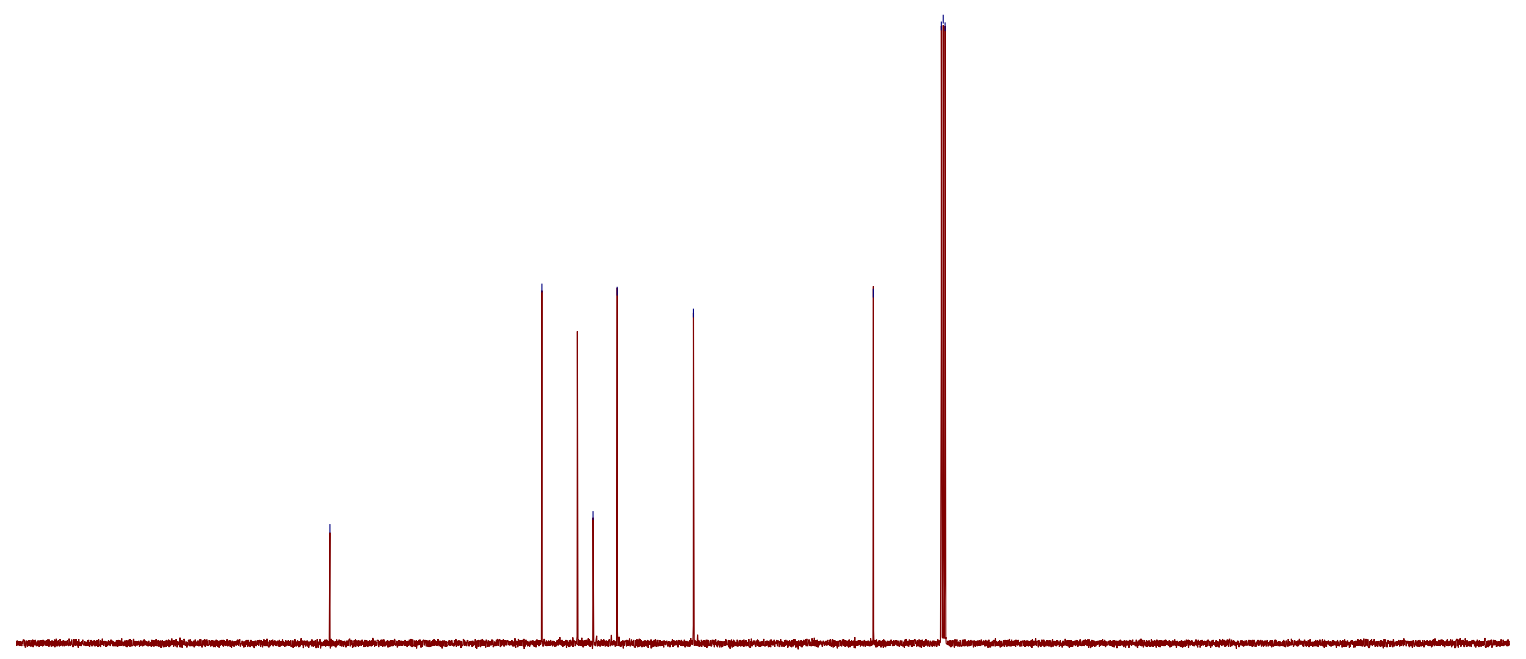

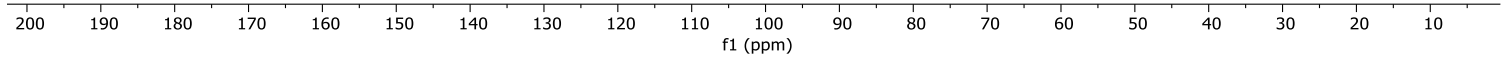




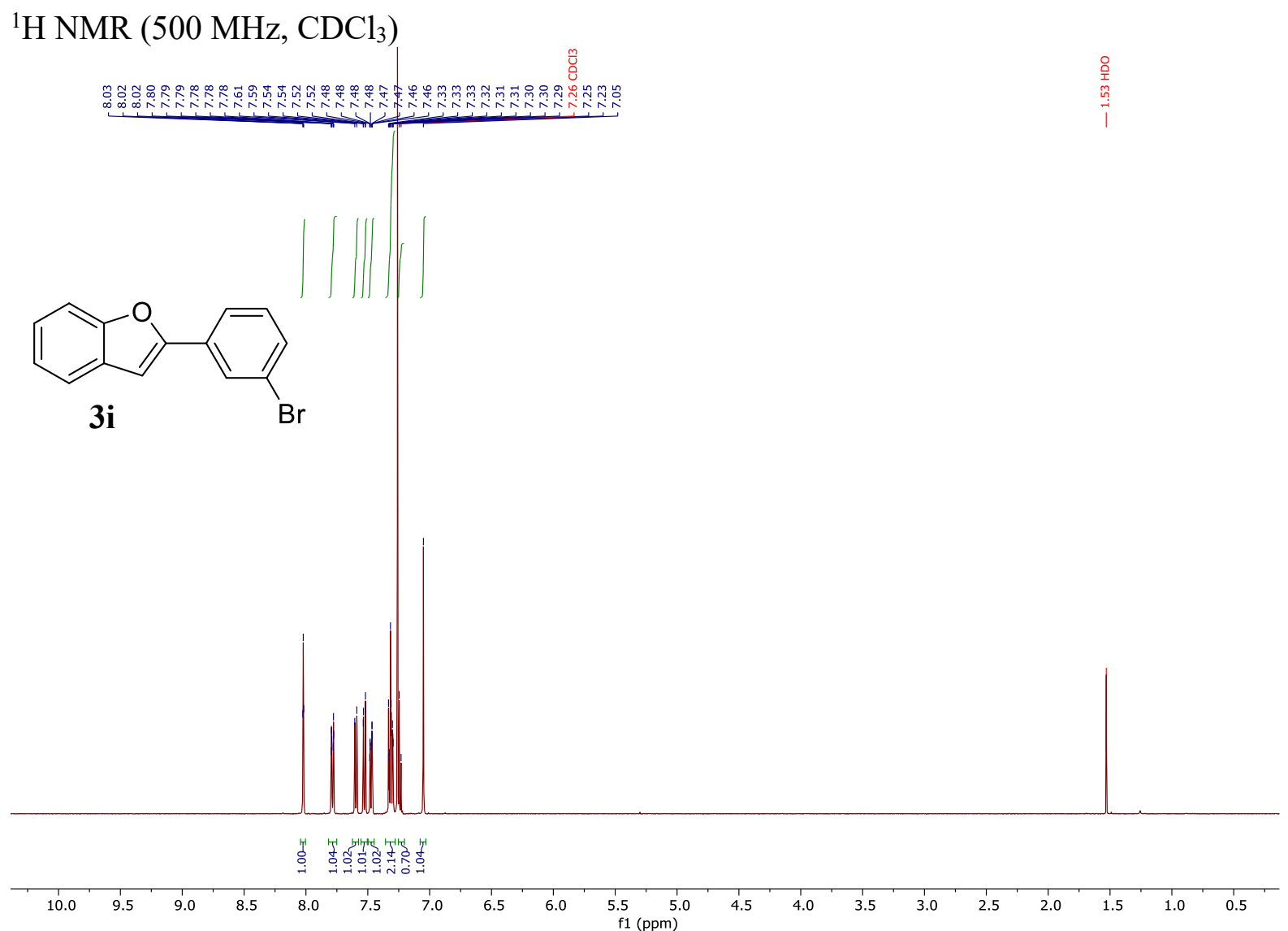

${ }^{13} \mathrm{C} \mathrm{NMR}\left(126 \mathrm{MHz}, \mathrm{CDCl}_{3}\right)$

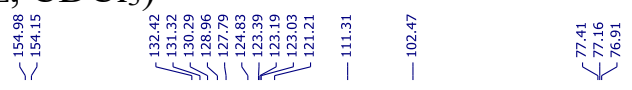

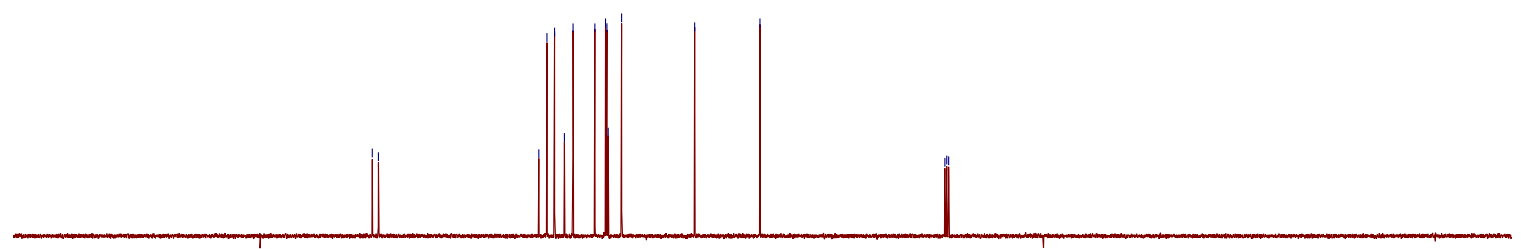

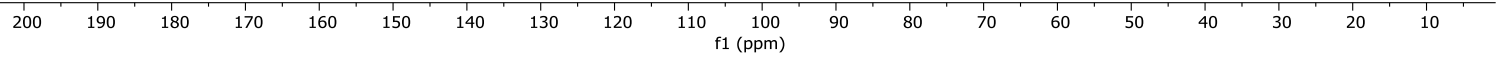




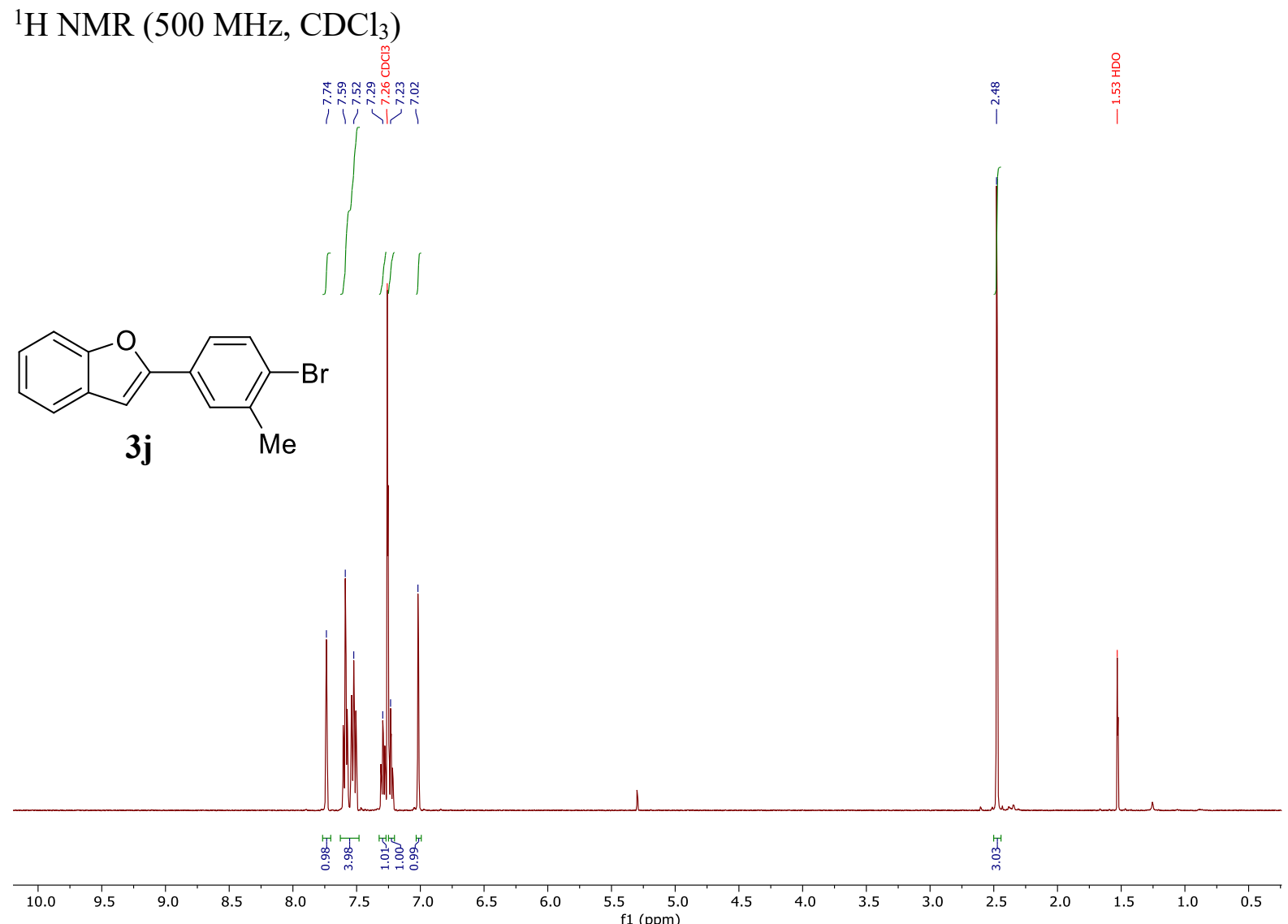

${ }^{13} \mathrm{C}$ NMR (126 MHz, $\left.\mathrm{CDCl}_{3}\right)$

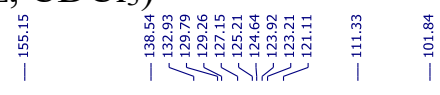


${ }^{1} \mathrm{H} \mathrm{NMR}\left(500 \mathrm{MHz}, \mathrm{CDCl}_{3}\right)$

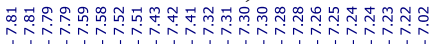
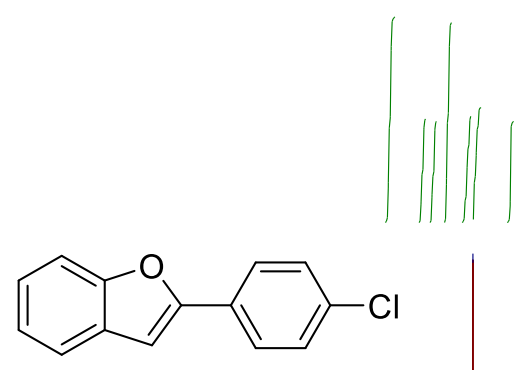

$3 \mathbf{k}$

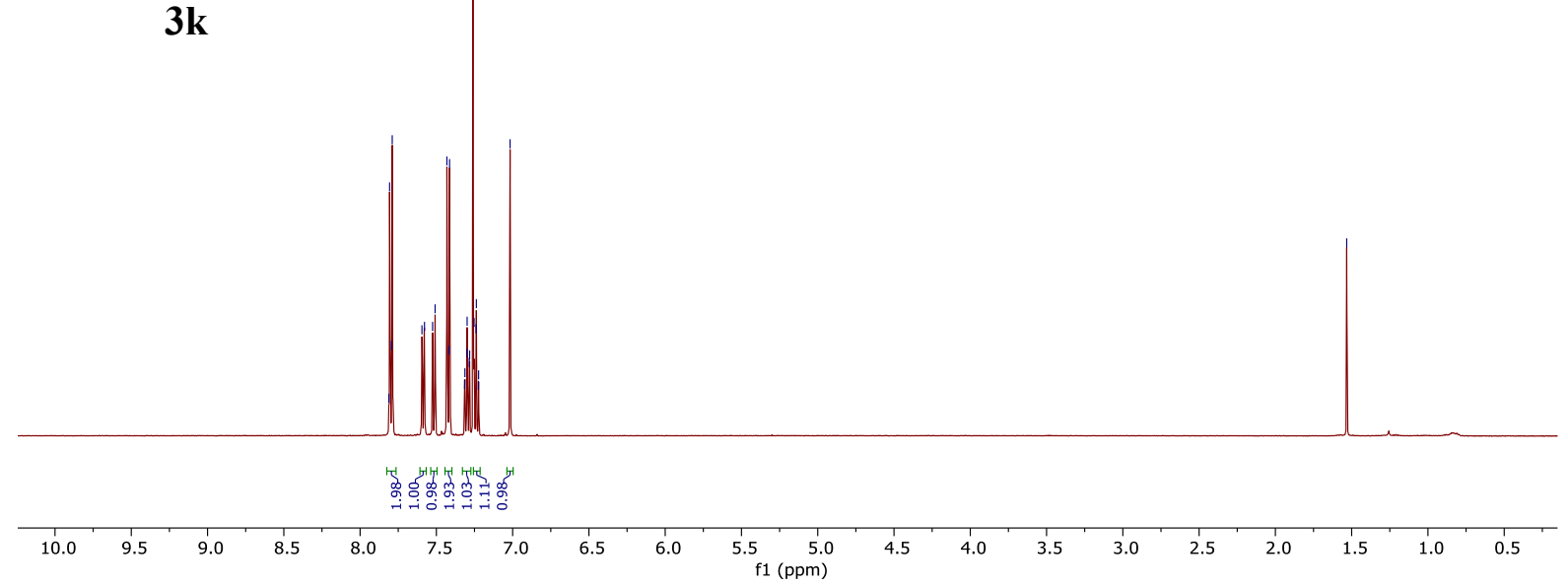

${ }^{13} \mathrm{C} \mathrm{NMR}\left(126 \mathrm{MHz}, \mathrm{CDCl}_{3}\right)$

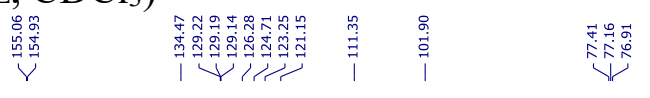

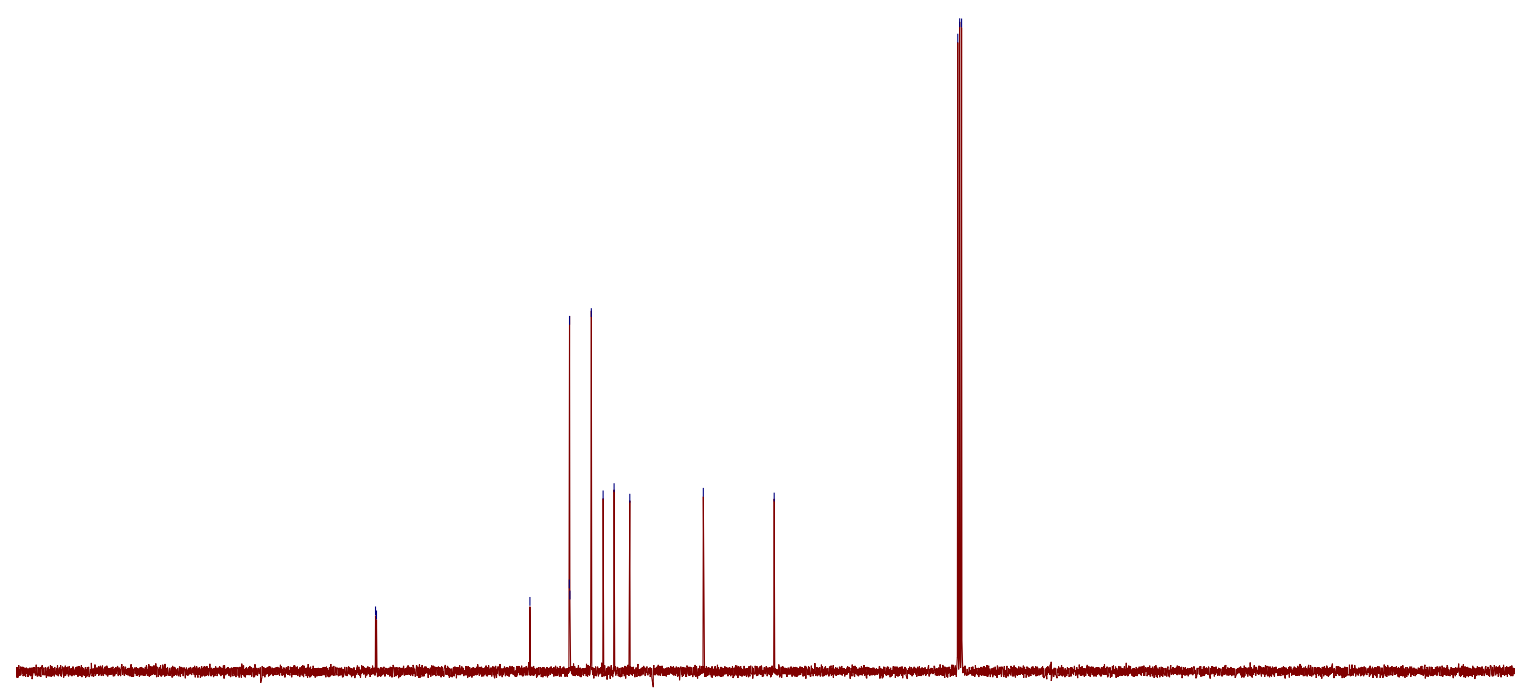

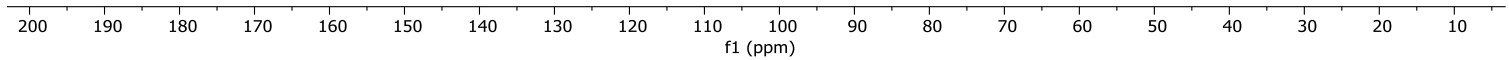




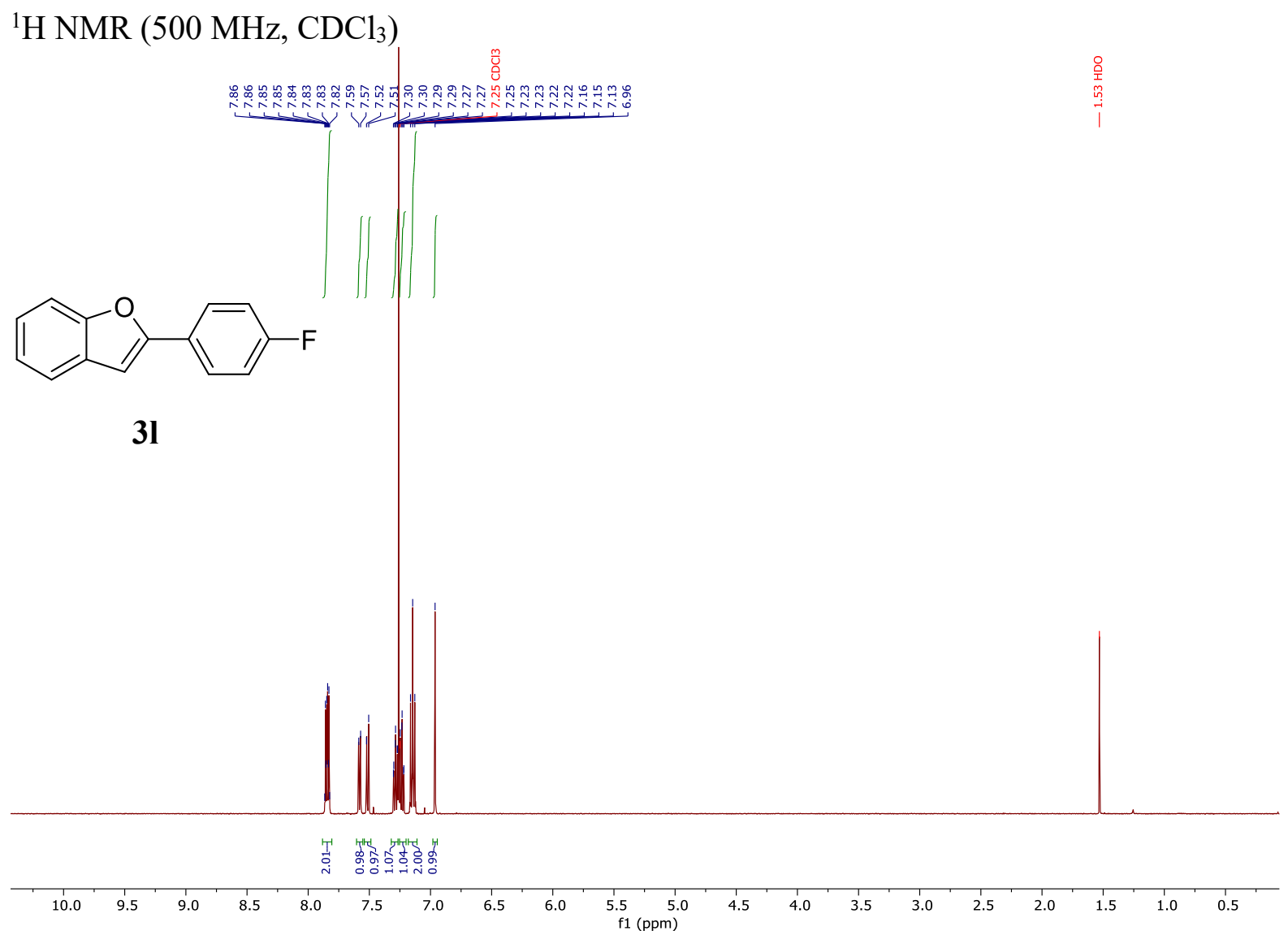

$\left.{ }^{13} \mathrm{C} \mathrm{NMR} \mathrm{(126} \mathrm{MHz,} \mathrm{CDCl}_{3}\right)$
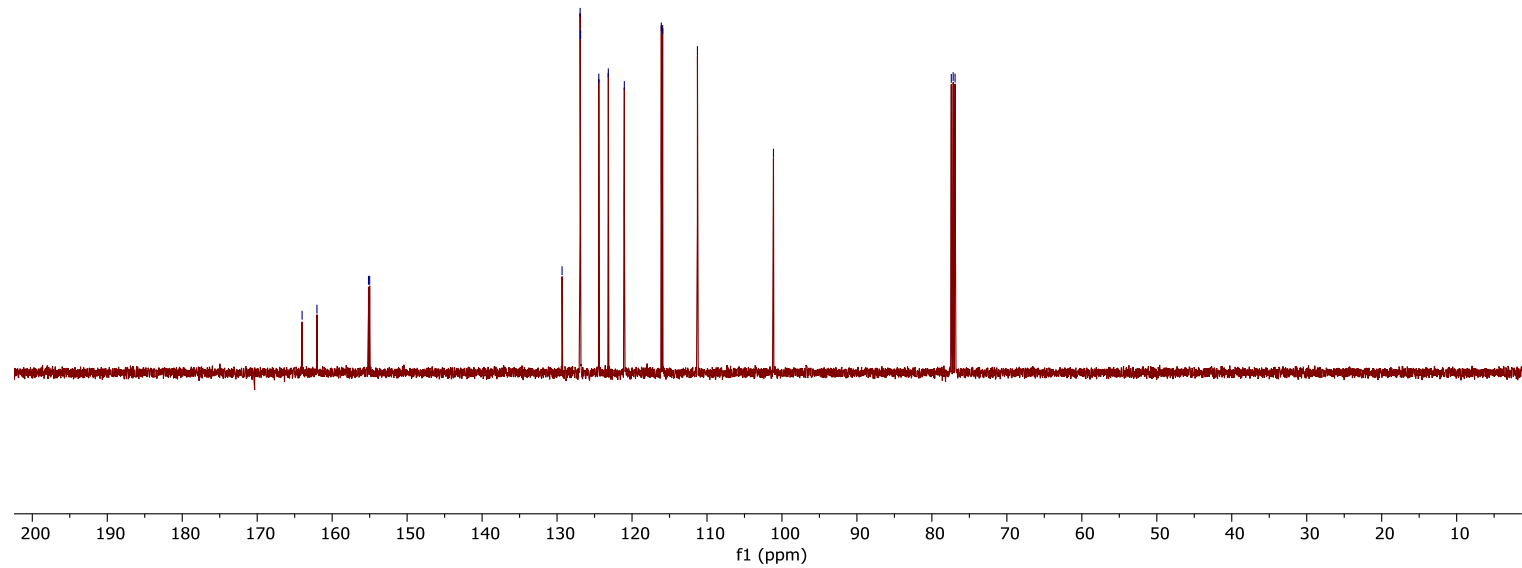
${ }^{1} \mathrm{H} \mathrm{NMR}\left(500 \mathrm{MHz}, \mathrm{CDCl}_{3}\right)$

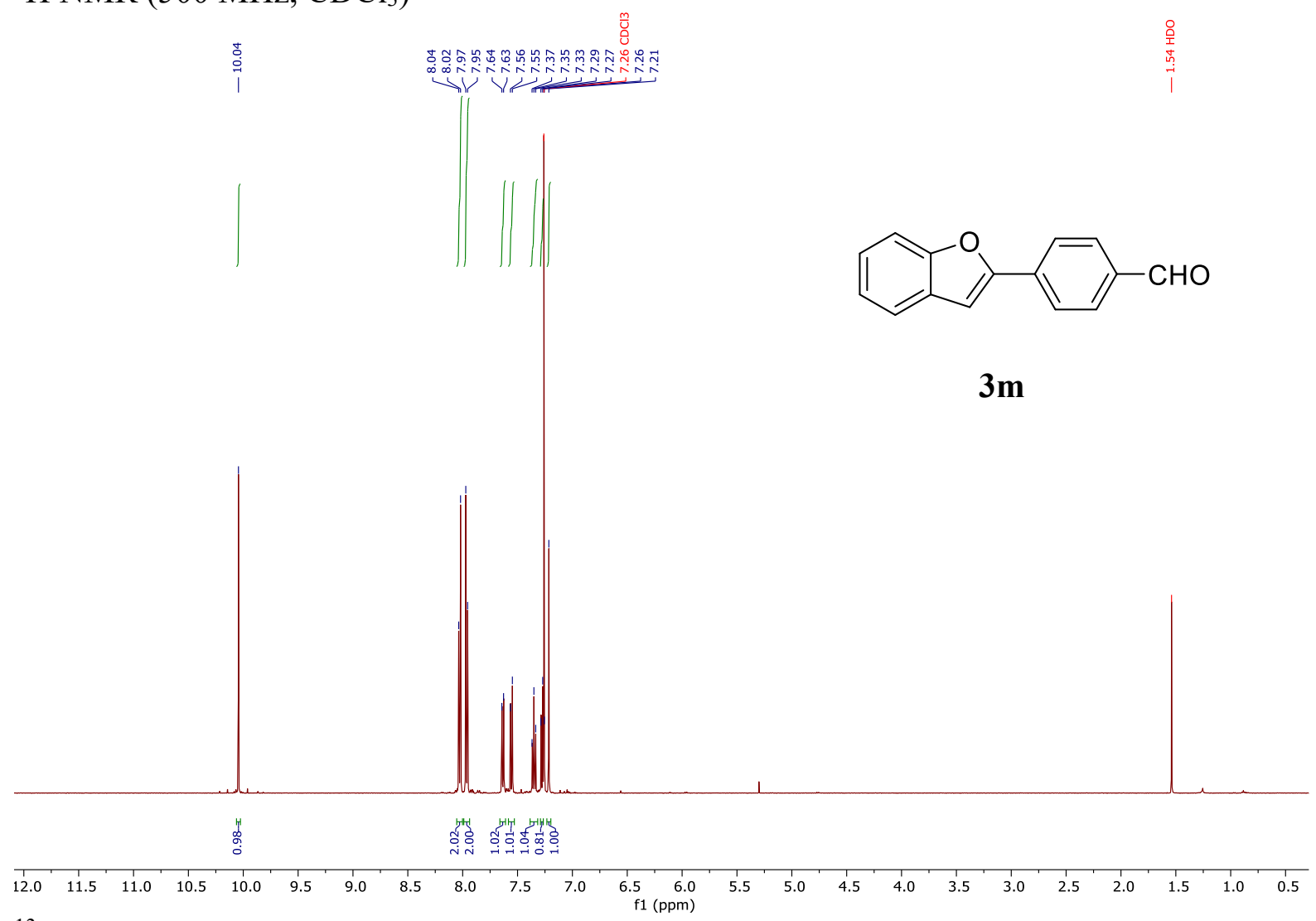

${ }^{13} \mathrm{C} \mathrm{NMR}\left(126 \mathrm{MHz}, \mathrm{CDCl}_{3}\right)$
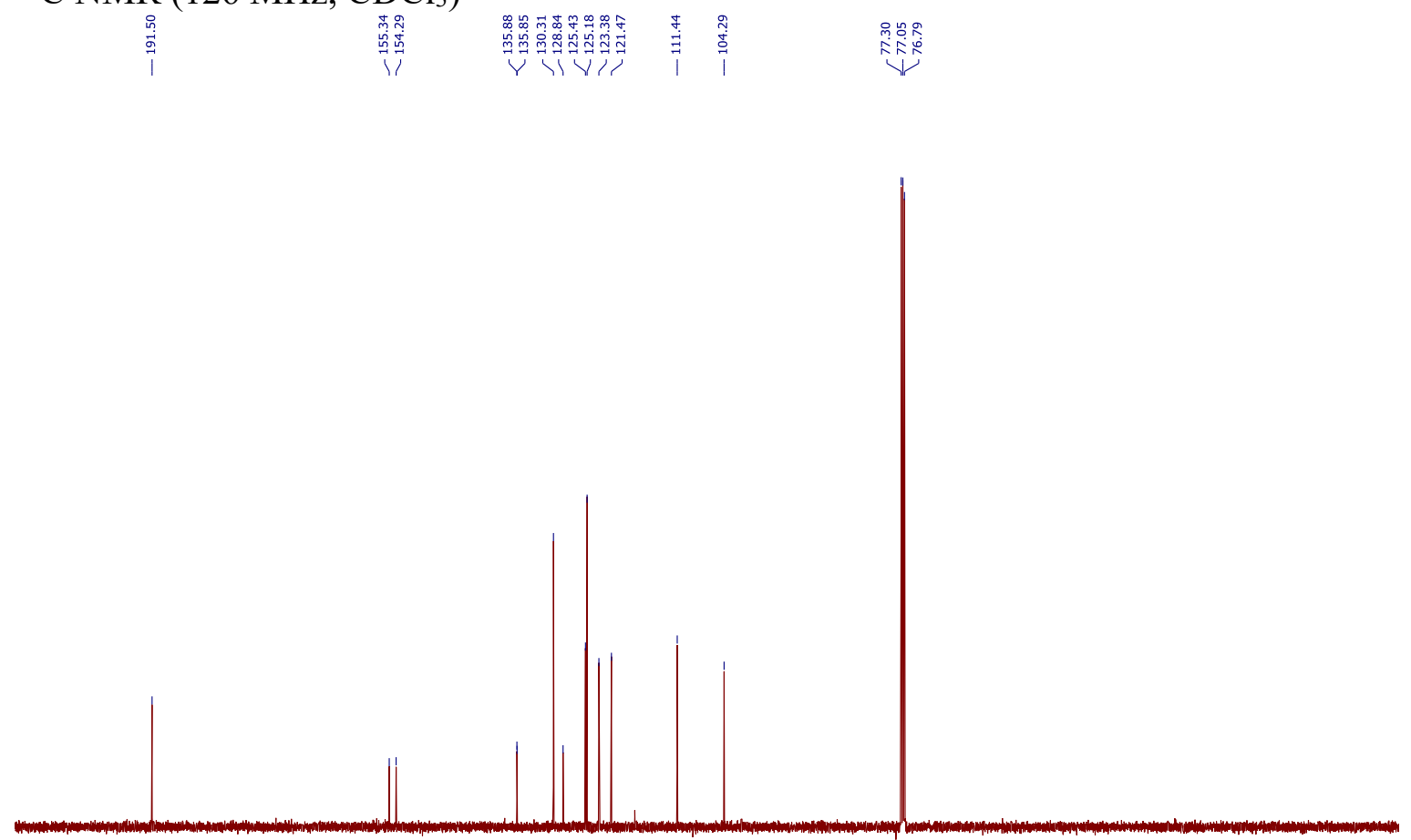

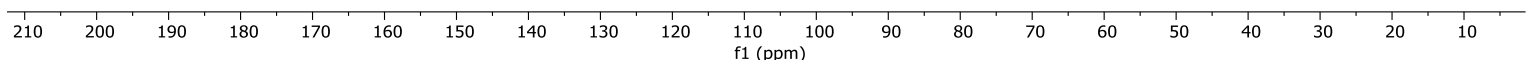


${ }^{1} \mathrm{H}$ NMR (500 MHz, $\mathrm{CDCl}_{3}$ )

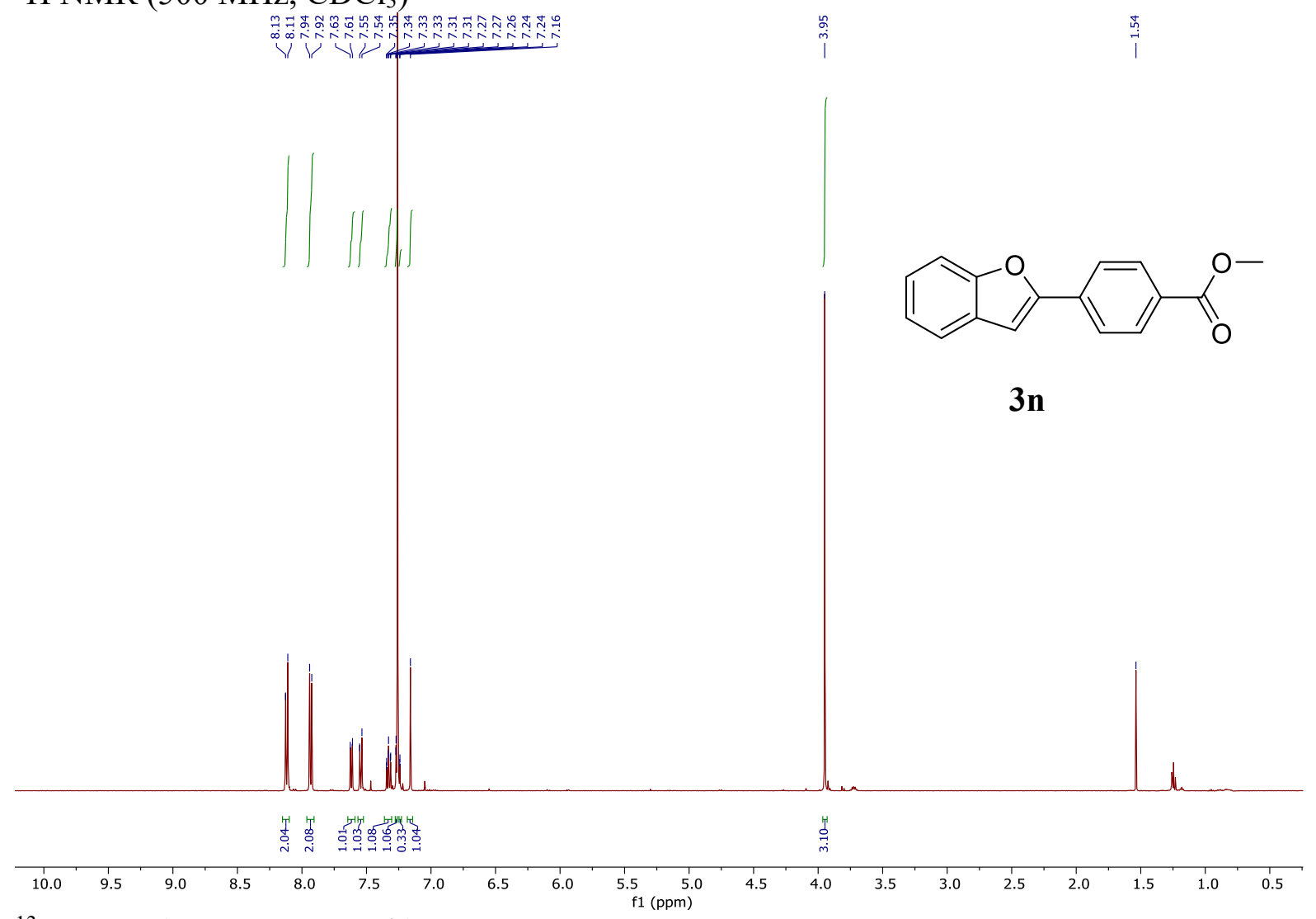

${ }^{13} \mathrm{C}$ NMR $\left(126 \mathrm{MHz}, \mathrm{CDCl}_{3}\right)$

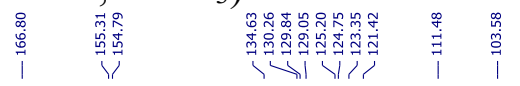

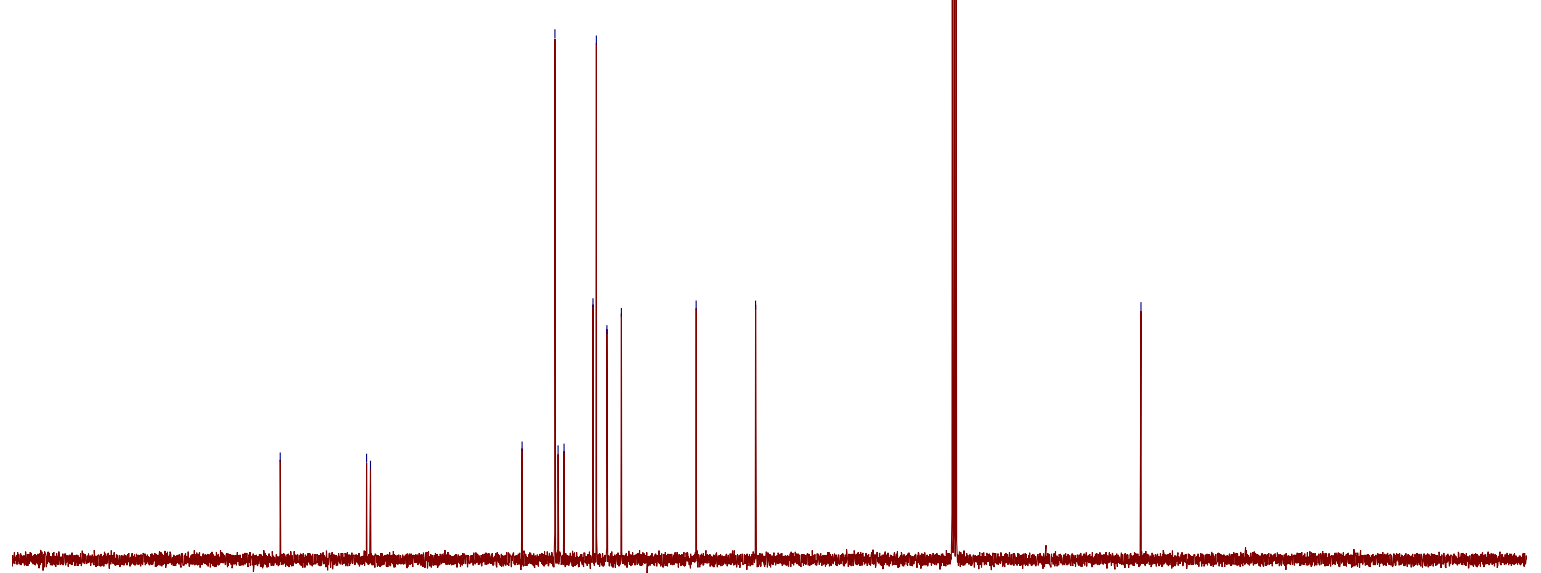

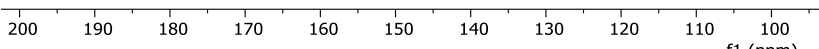


${ }^{1} \mathrm{H} \mathrm{NMR}\left(500 \mathrm{MHz}, \mathrm{CDCl}_{3}\right)$

Y.
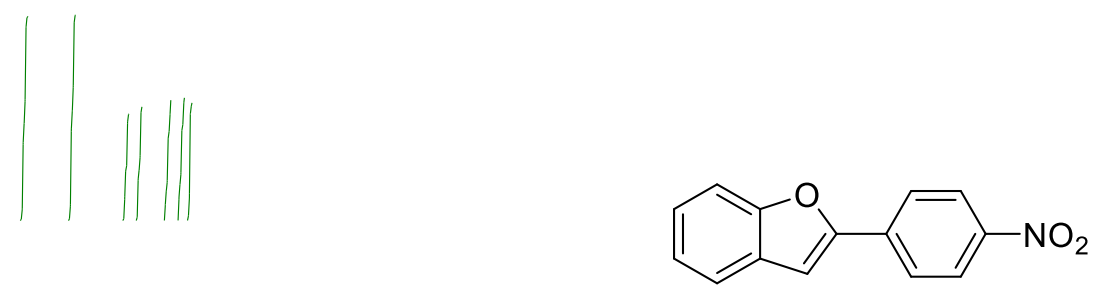

30

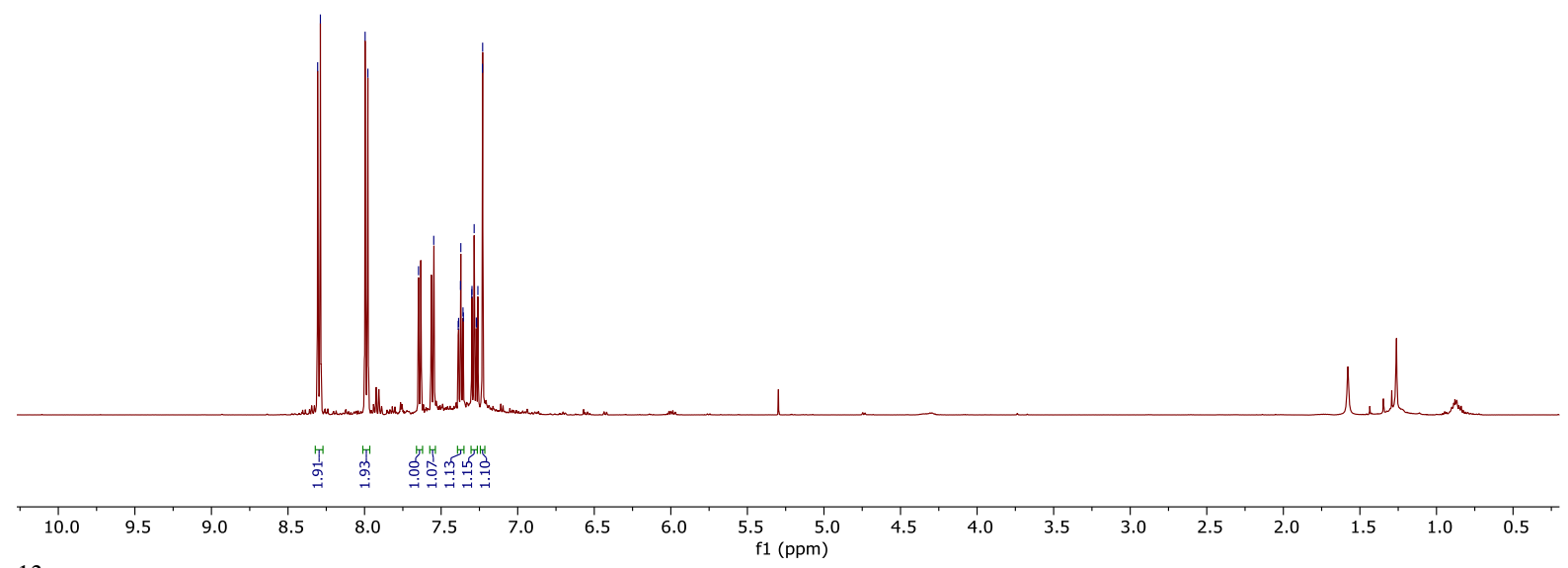

${ }^{13} \mathrm{C} \mathrm{NMR}\left(126 \mathrm{MHz}, \mathrm{CDCl}_{3}\right)$

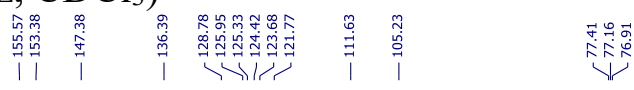

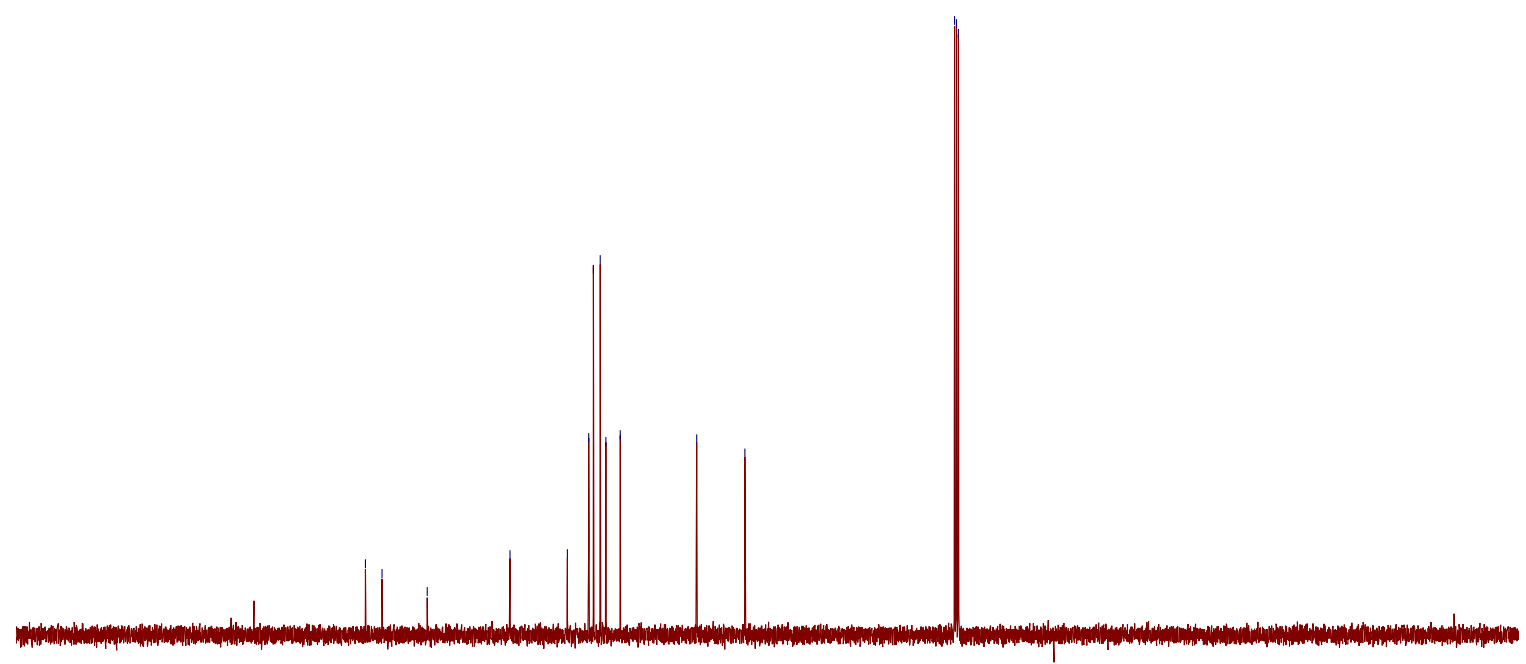

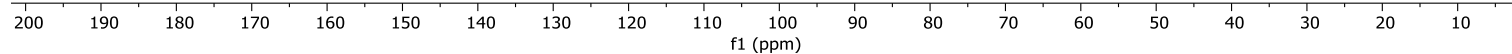


${ }^{1} \mathrm{H}$ NMR (500 MHz, $\mathrm{CDCl}_{3}$ )

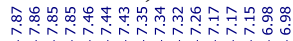

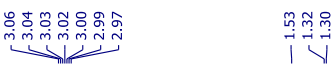

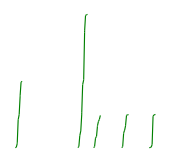

(1)

$3 p$

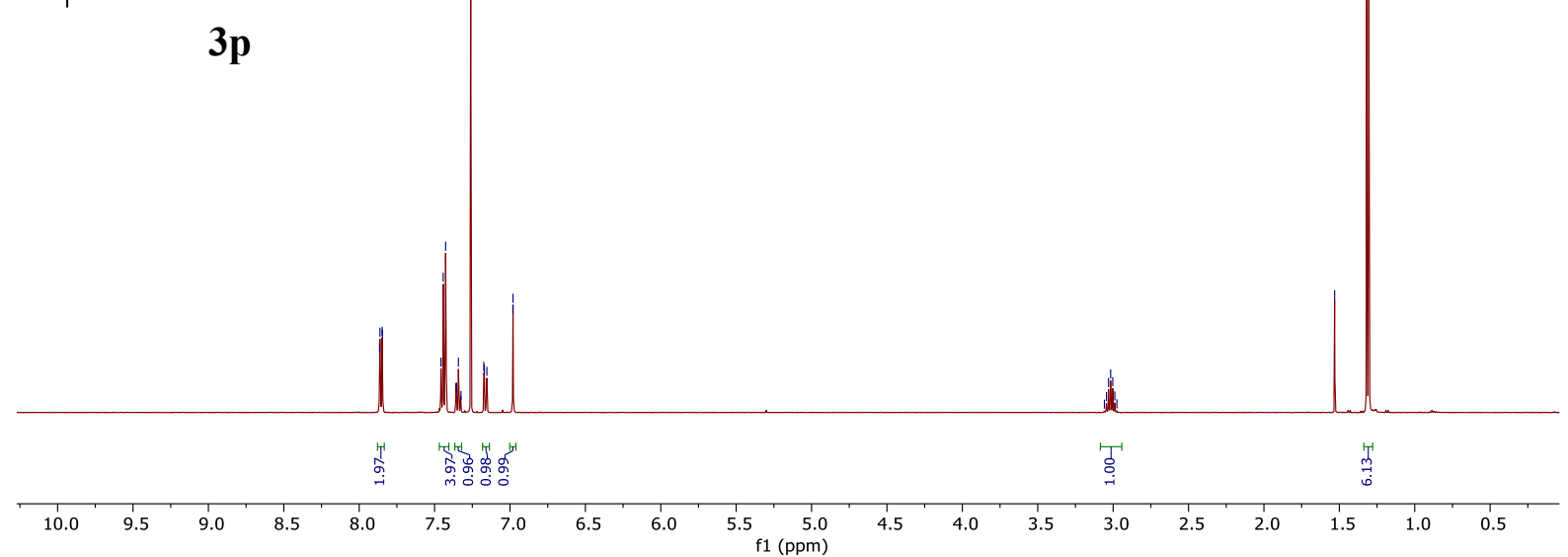

${ }^{13} \mathrm{C}$ NMR (126 MHz, $\mathrm{CDCl}_{3}$ )

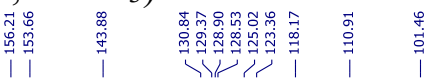

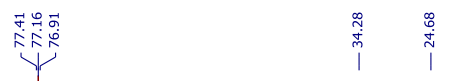

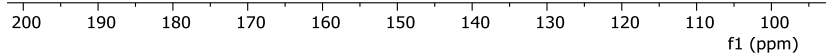


${ }^{1} \mathrm{H} \mathrm{NMR}\left(300 \mathrm{MHz}, \mathrm{CDCl}_{3}\right)$

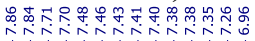

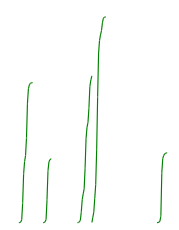<smiles>Brc1ccc2oc(-c3ccccc3)cc2c1</smiles>

$3 \mathbf{q}$

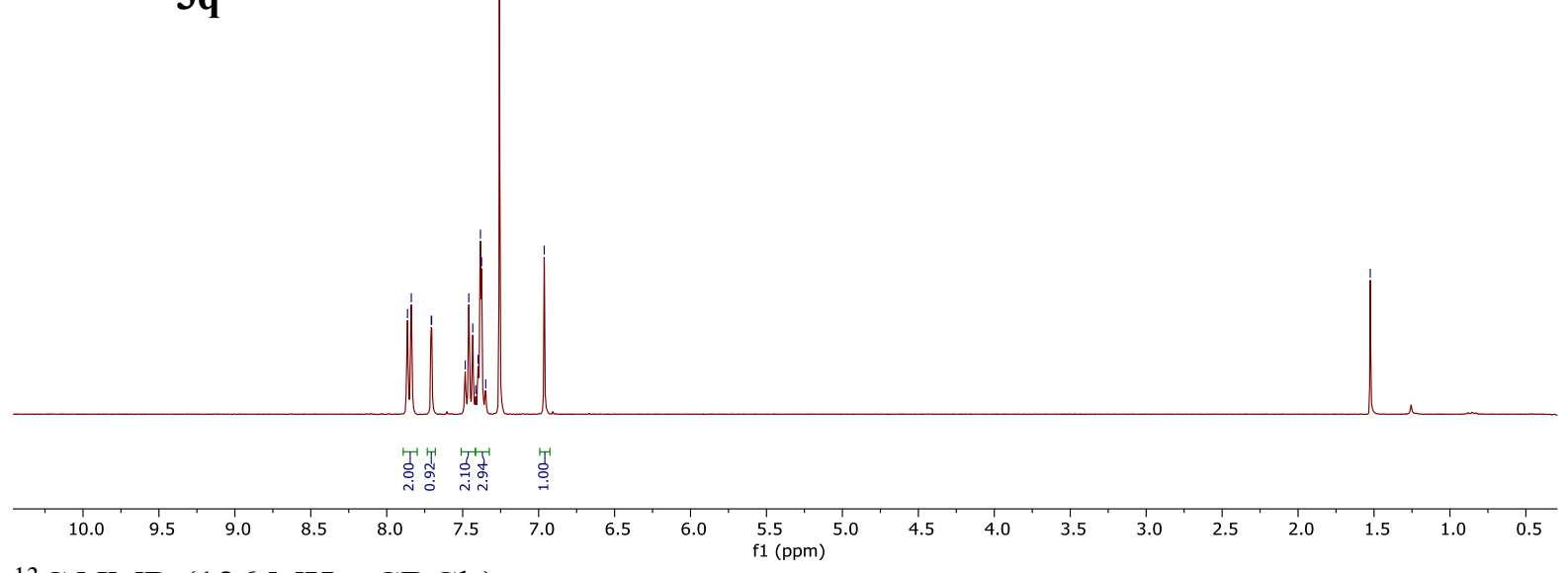

${ }^{13} \mathrm{C} \mathrm{NMR}\left(126 \mathrm{MHz}, \mathrm{CDCl}_{3}\right)$
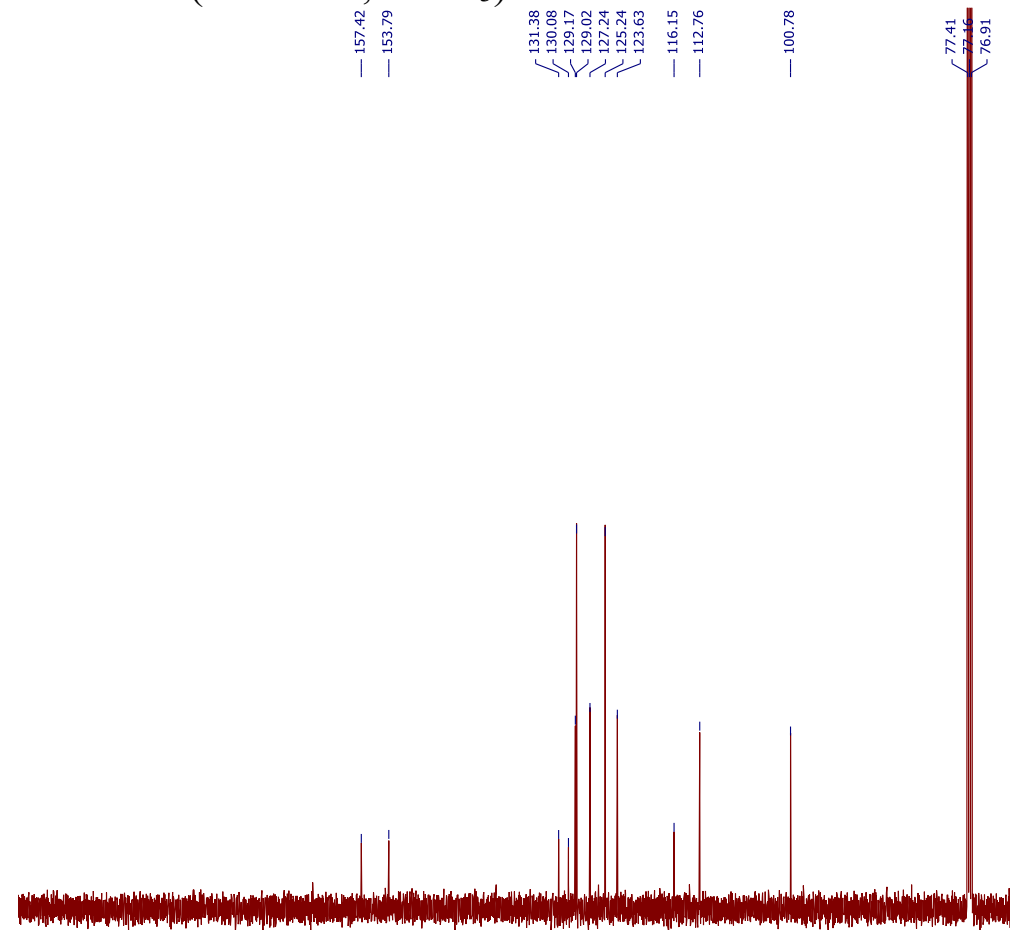

$\begin{array}{rlllllllll}200 & 190 & 180 & 170 & 160 & 150 & 140 & 130 & 120 & 110 \begin{array}{r}100 \\ \mathrm{f} 1(\mathrm{ppm})\end{array}\end{array}$ 
${ }^{1} \mathrm{H}$ NMR (500 MHz, $\mathrm{CDCl}_{3}$ )

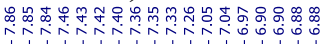

$\stackrel{\infty}{1}$

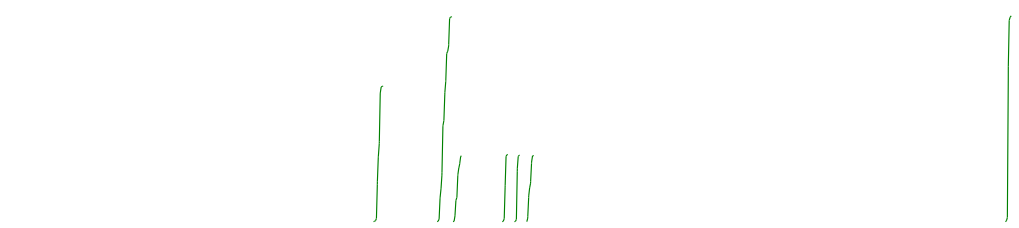<smiles>COc1ccc2oc(-c3ccccc3)cc2c1</smiles>

$3 \mathbf{r}$

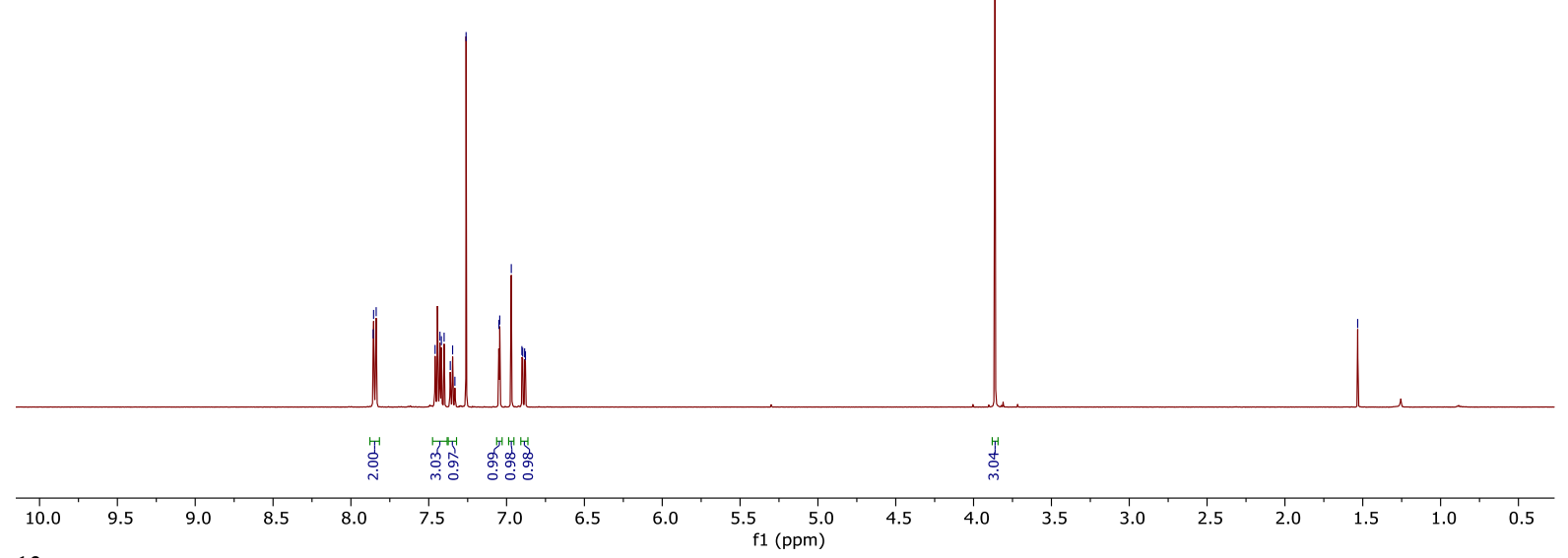

$\left.{ }^{13} \mathrm{C} \mathrm{NMR} \mathrm{(126} \mathrm{MHz,} \mathrm{CDCl}_{3}\right)$

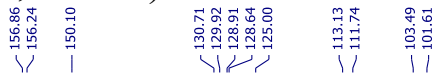
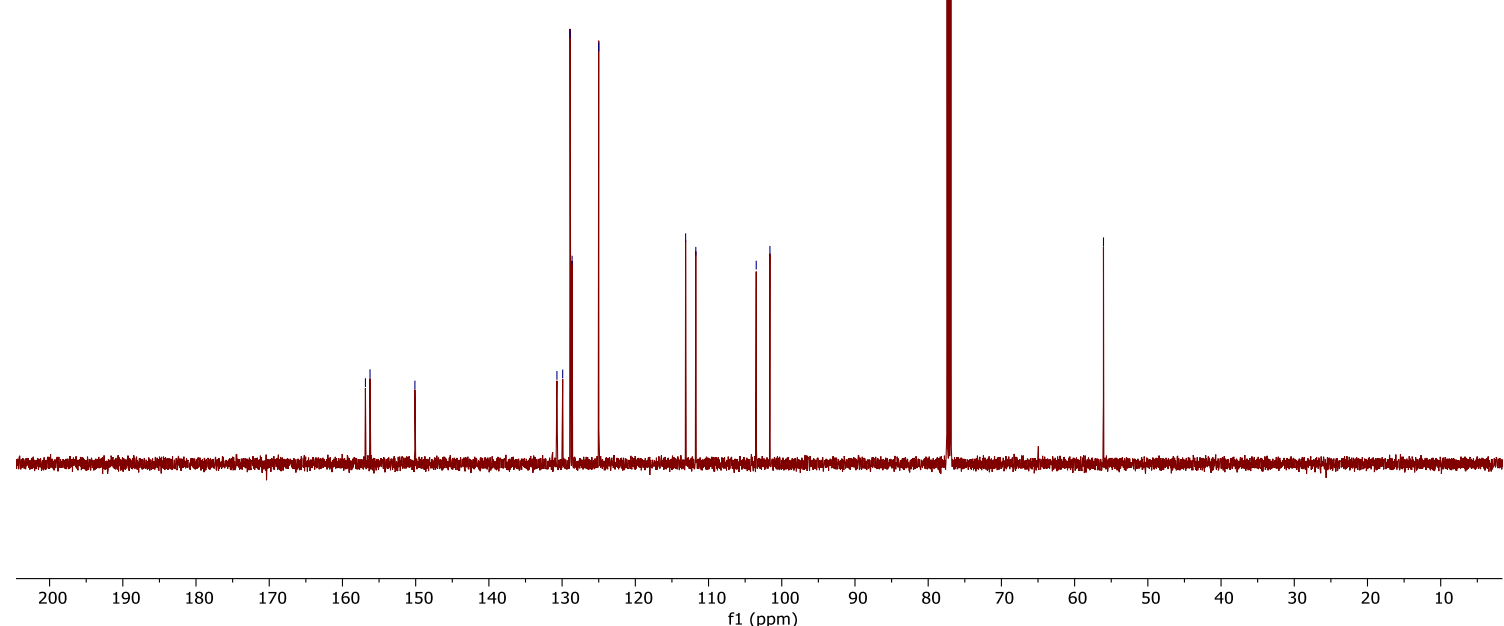


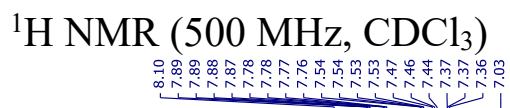
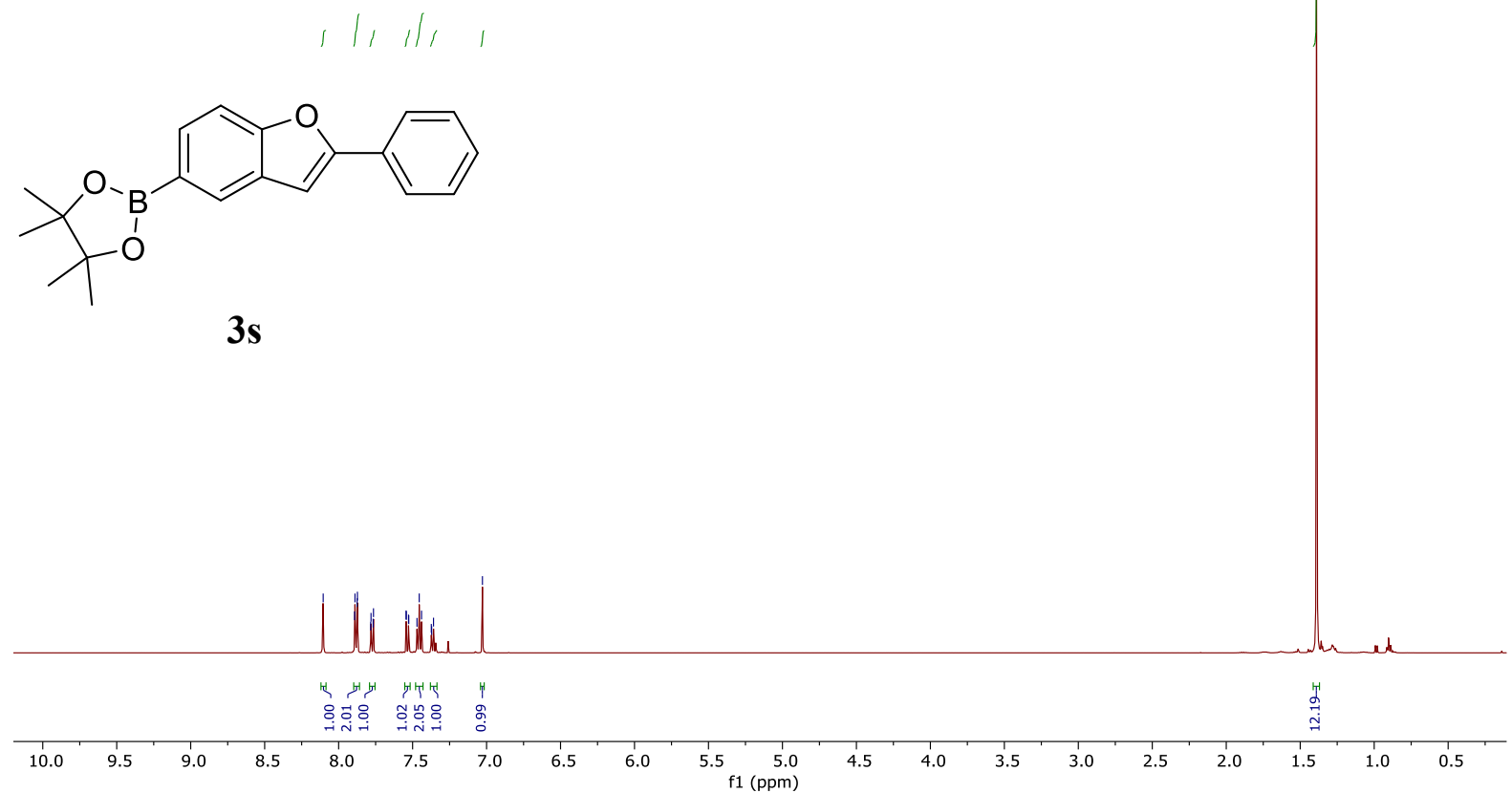

${ }^{13} \mathrm{C}$ NMR $\left(126 \mathrm{MHz}, \mathrm{CDCl}_{3}\right)$

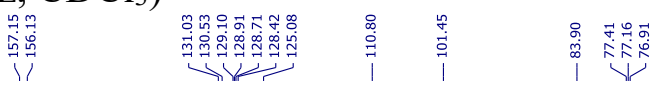

号
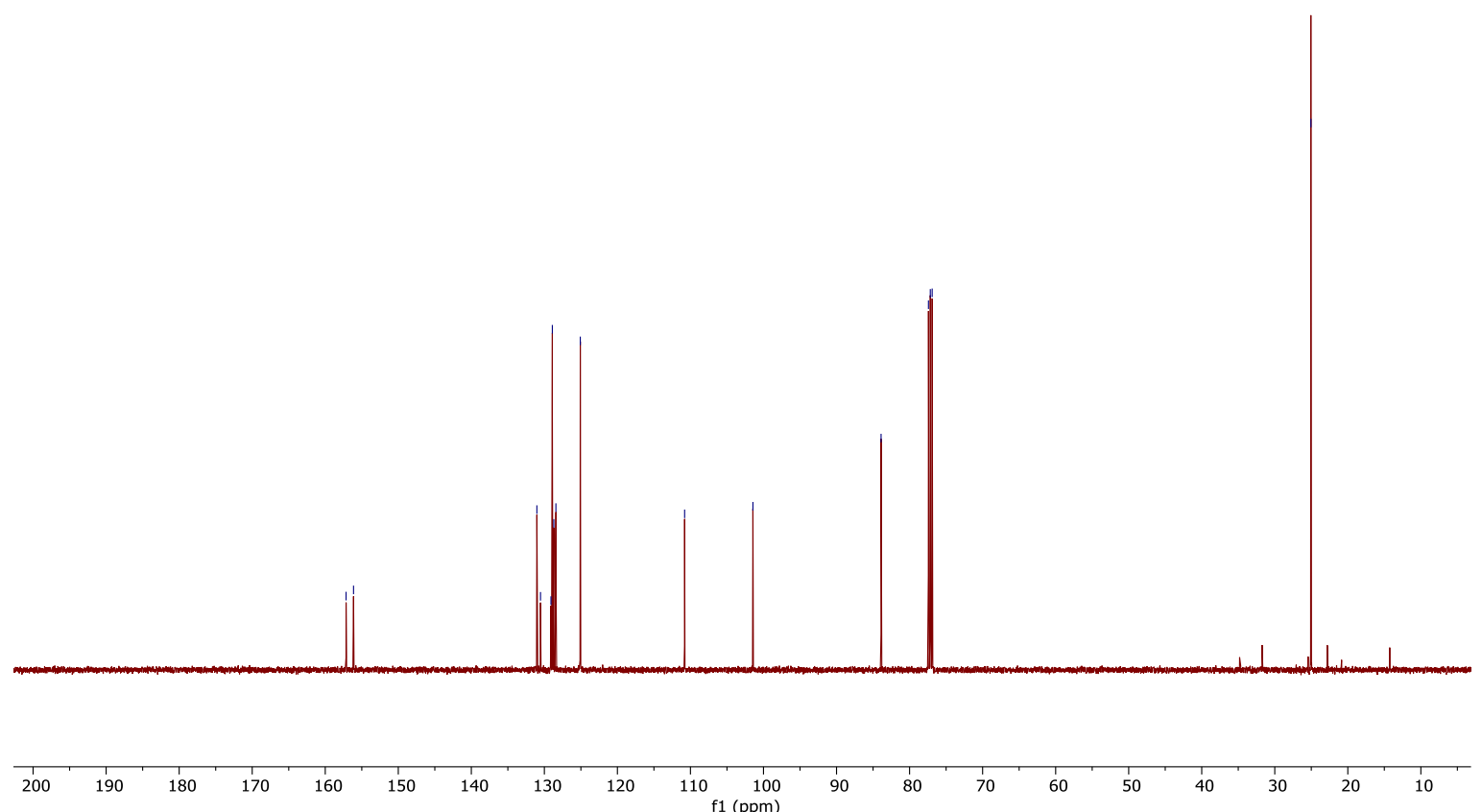
${ }^{1} \mathrm{H}$ NMR (500 MHz, $\mathrm{CDCl}_{3}$ )

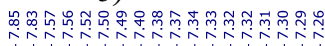

$\stackrel{\vec{n}}{i}$

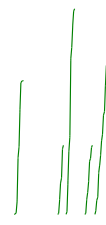

Me

$3 t$

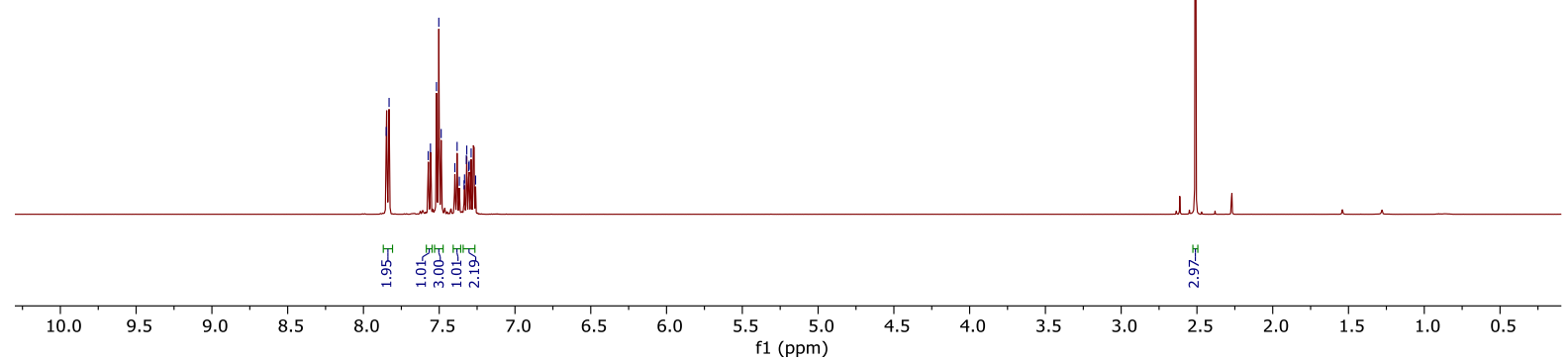

${ }^{13} \mathrm{C} \mathrm{NMR}\left(126 \mathrm{MHz}, \mathrm{CDCl}_{3}\right)$
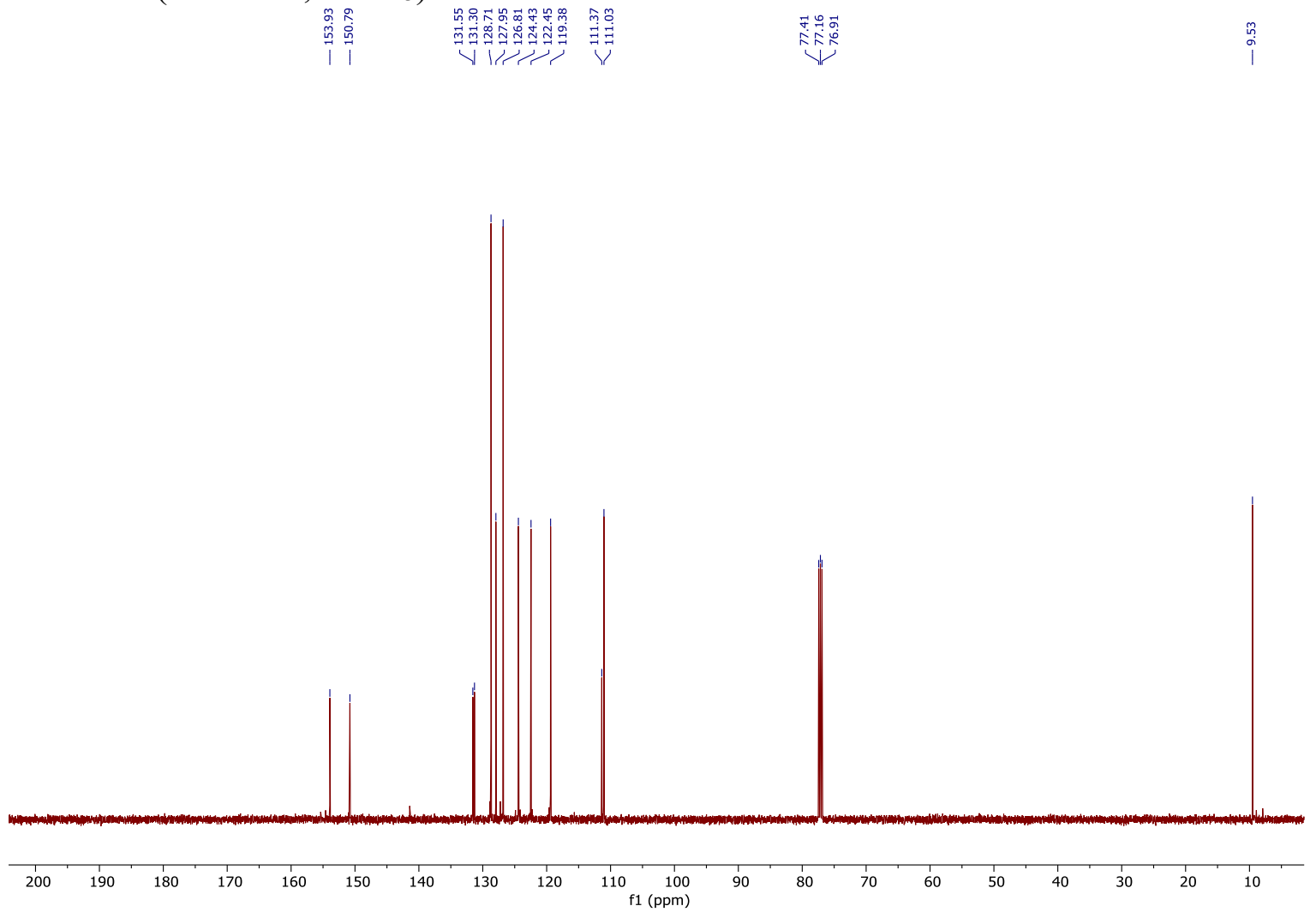
${ }^{1} \mathrm{H} \mathrm{NMR}\left(500 \mathrm{MHz}, \mathrm{CDCl}_{3}\right)$

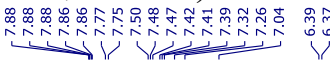

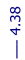

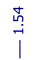

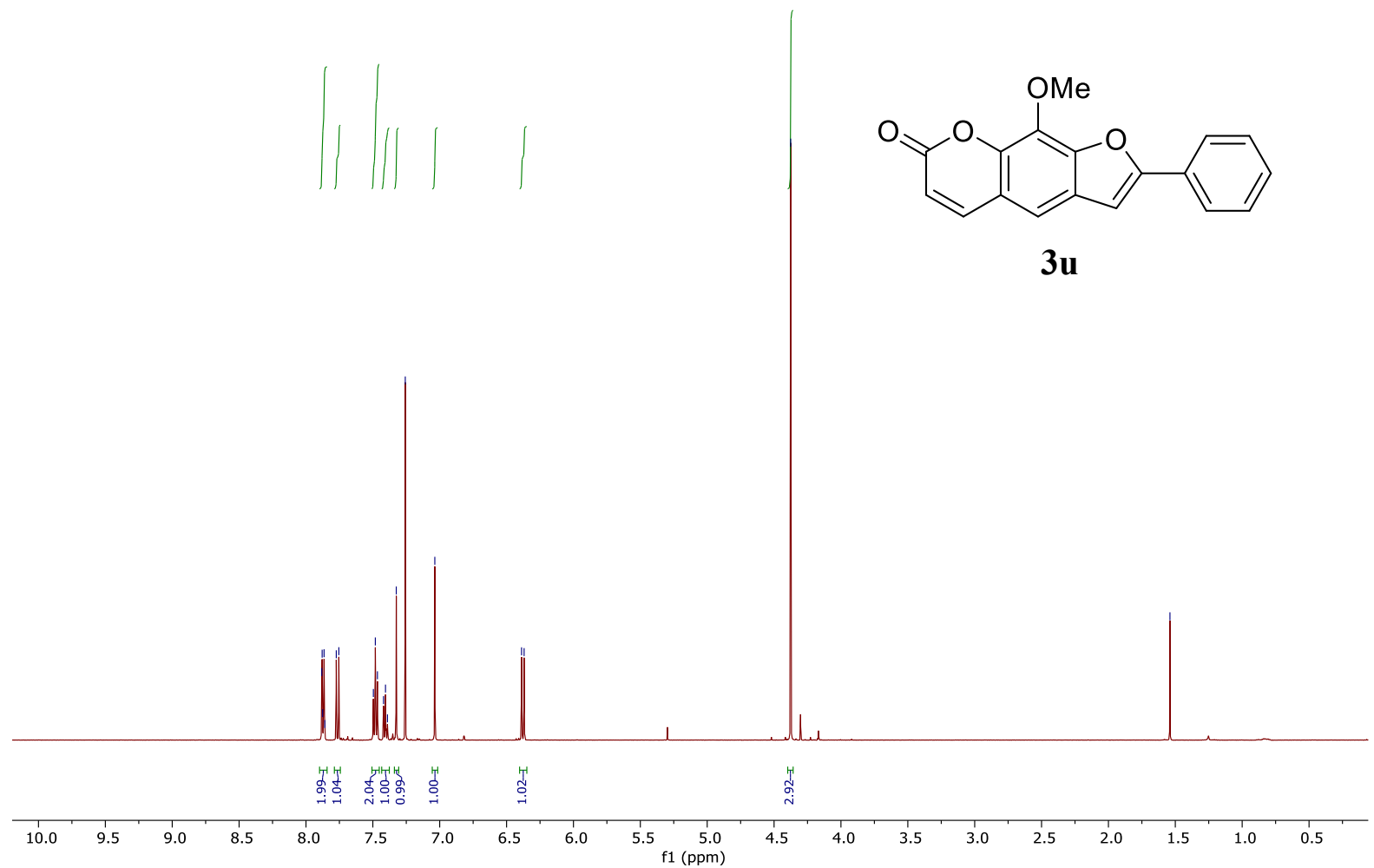

${ }^{13} \mathrm{C}$ NMR (75 MHz, $\left.\mathrm{CDCl}_{3}\right)$

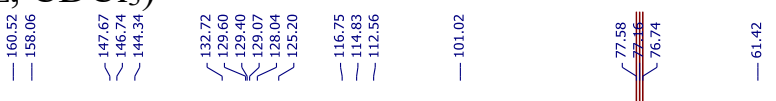

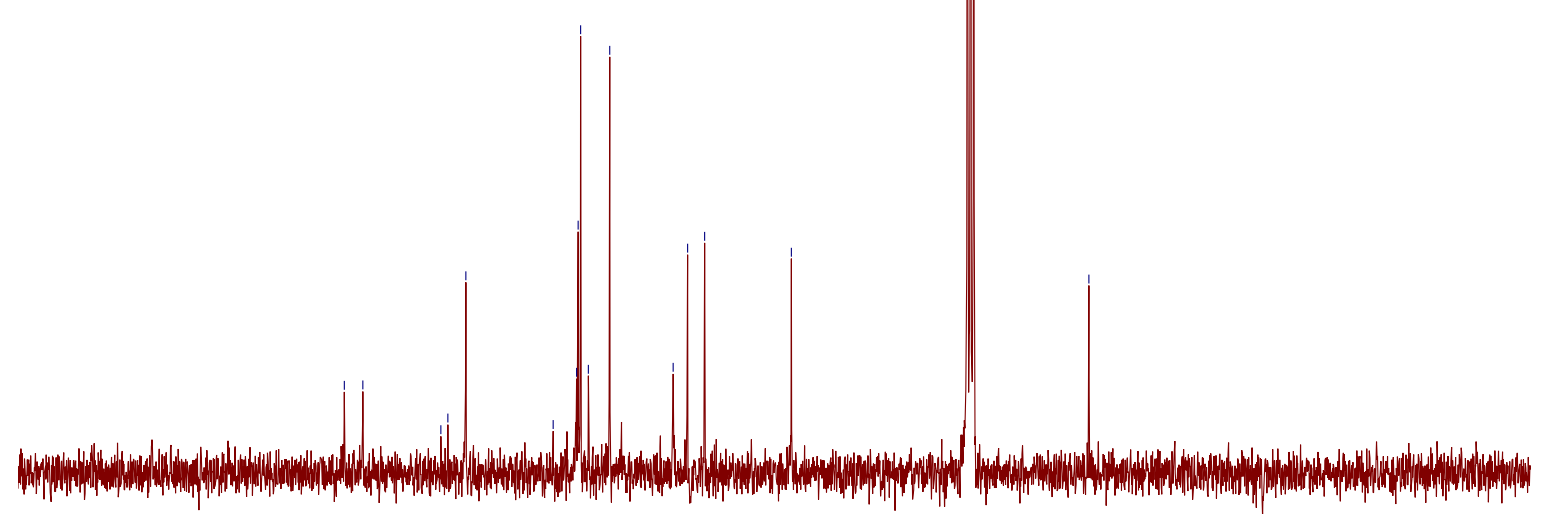

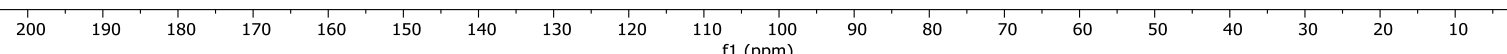


${ }^{1} \mathrm{H} \mathrm{NMR}\left(500 \mathrm{MHz}, \mathrm{CDCl}_{3}\right)$

(1)

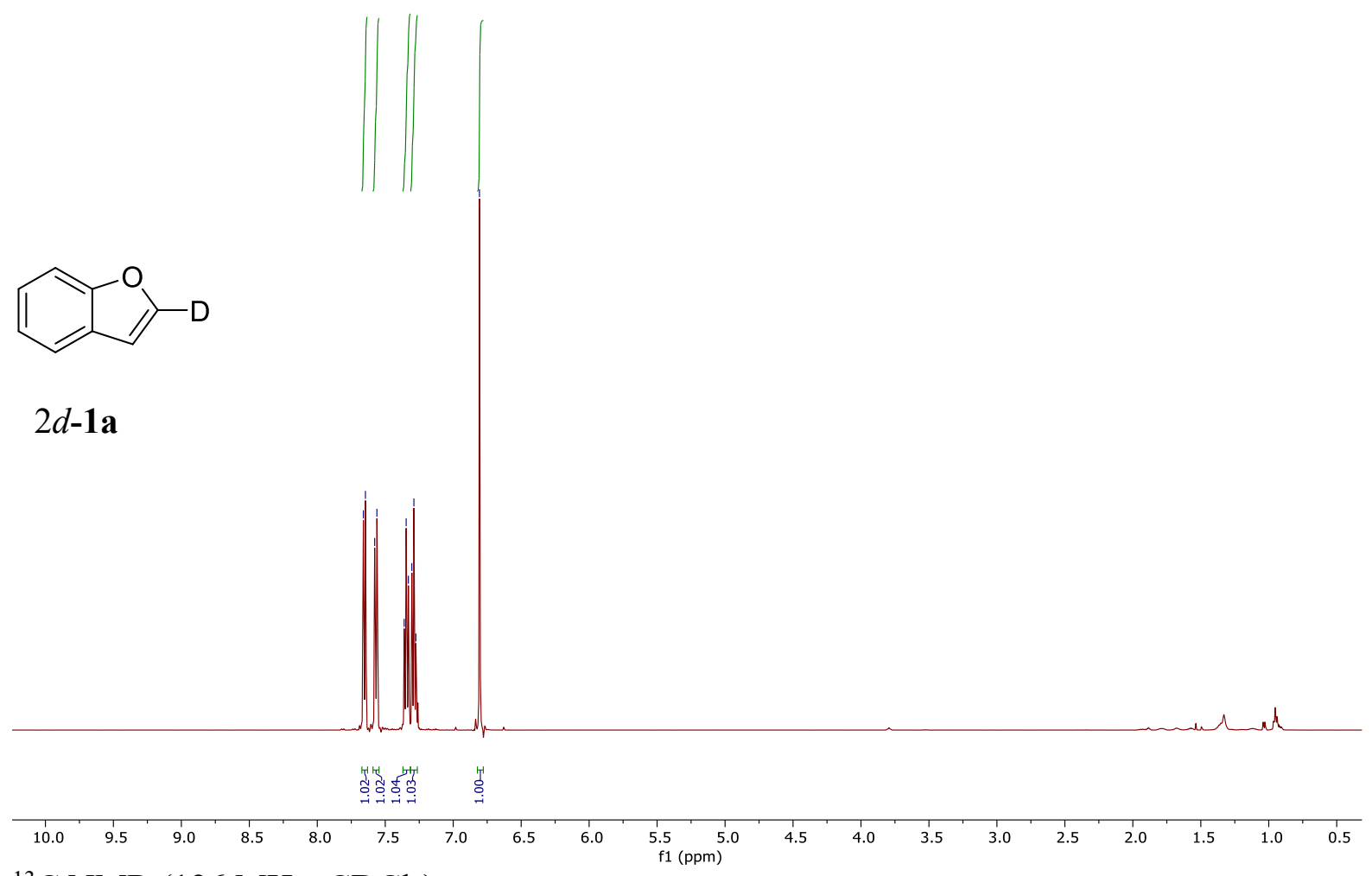

${ }^{13} \mathrm{C} \mathrm{NMR} \mathrm{(126} \mathrm{MHz,} \mathrm{CDCl}_{3}$ )

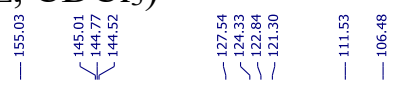
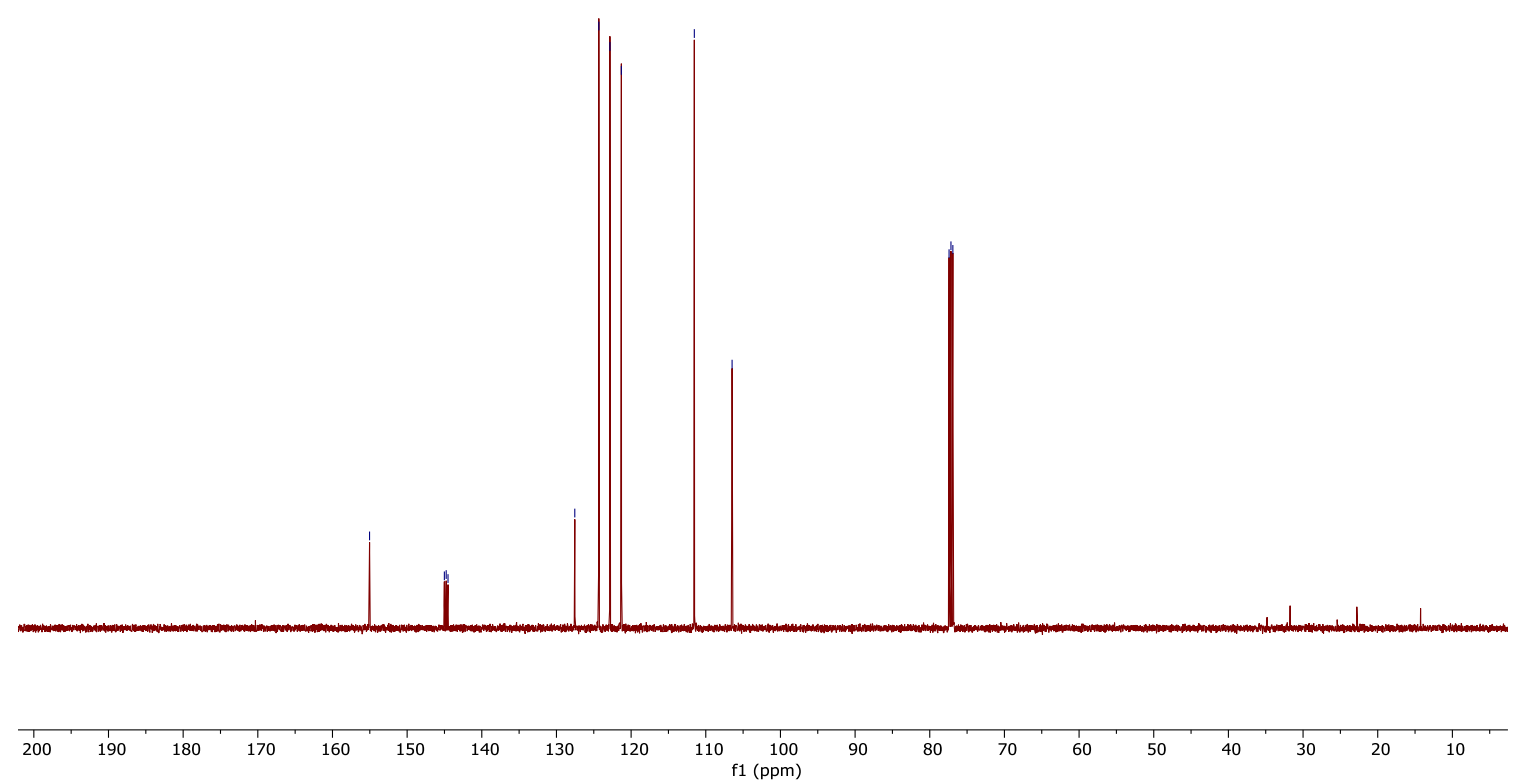
${ }^{1} \mathrm{H}$ NMR (500 MHz, $\mathrm{CDCl}_{3}$ )

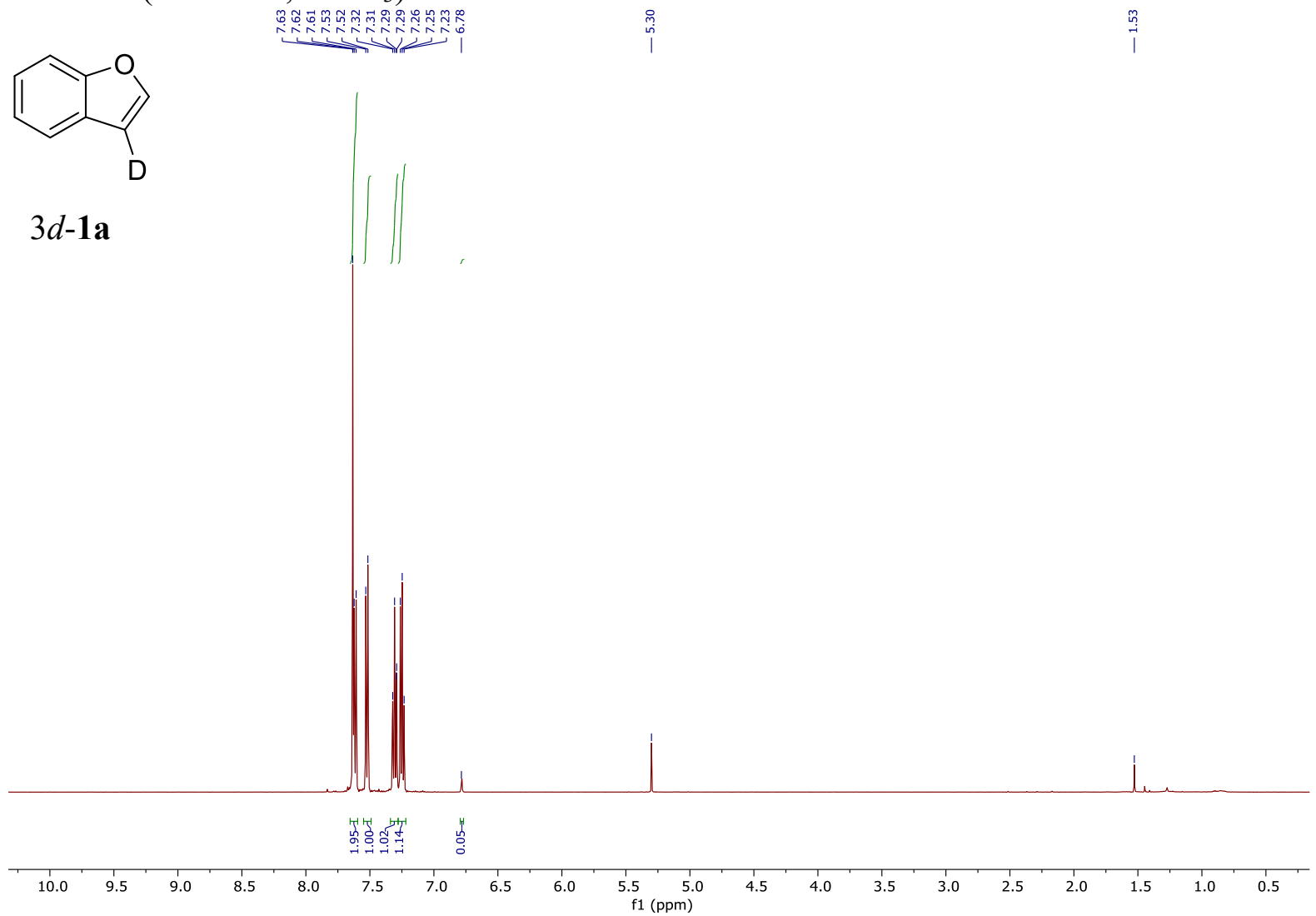

${ }^{13} \mathrm{C}$ NMR (126 MHz, $\mathrm{CDCl}_{3}$ )

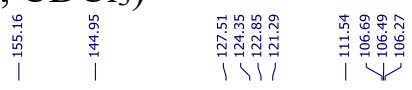

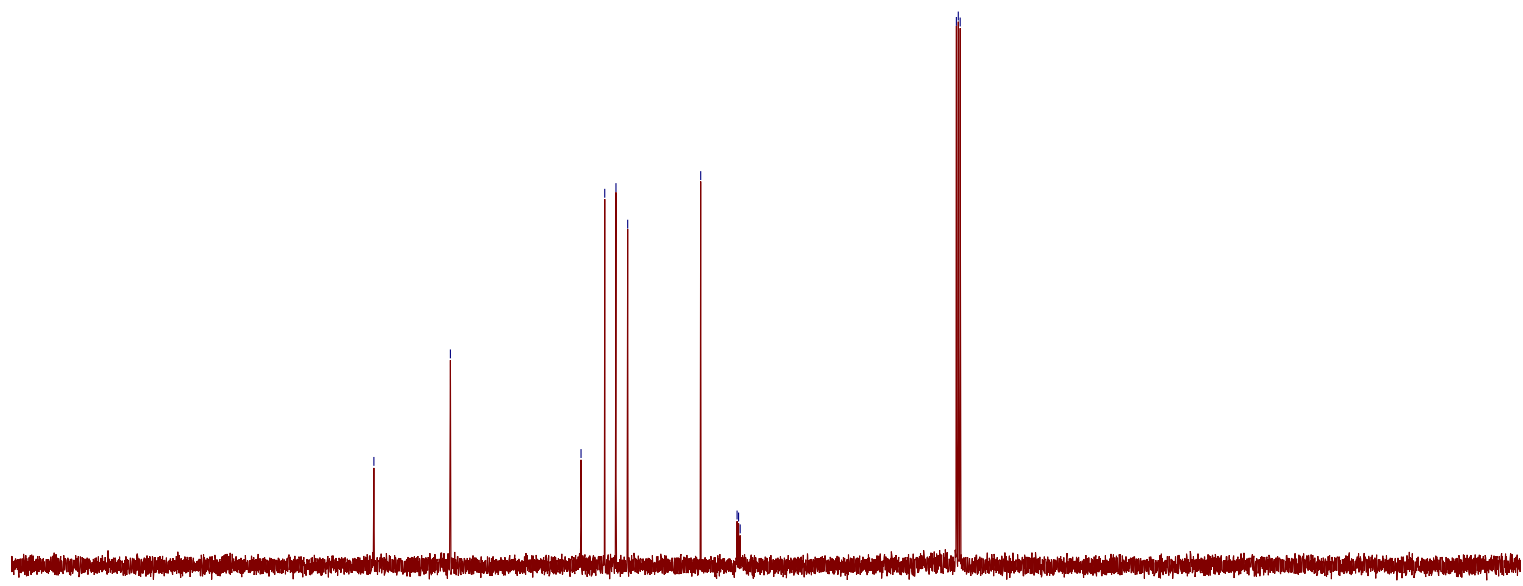

200

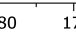

160

$150 \cdot 140$

$\begin{array}{llr}120 & 110 & 100 \\ \mathrm{f} 1(\mathrm{ppm})\end{array}$ 


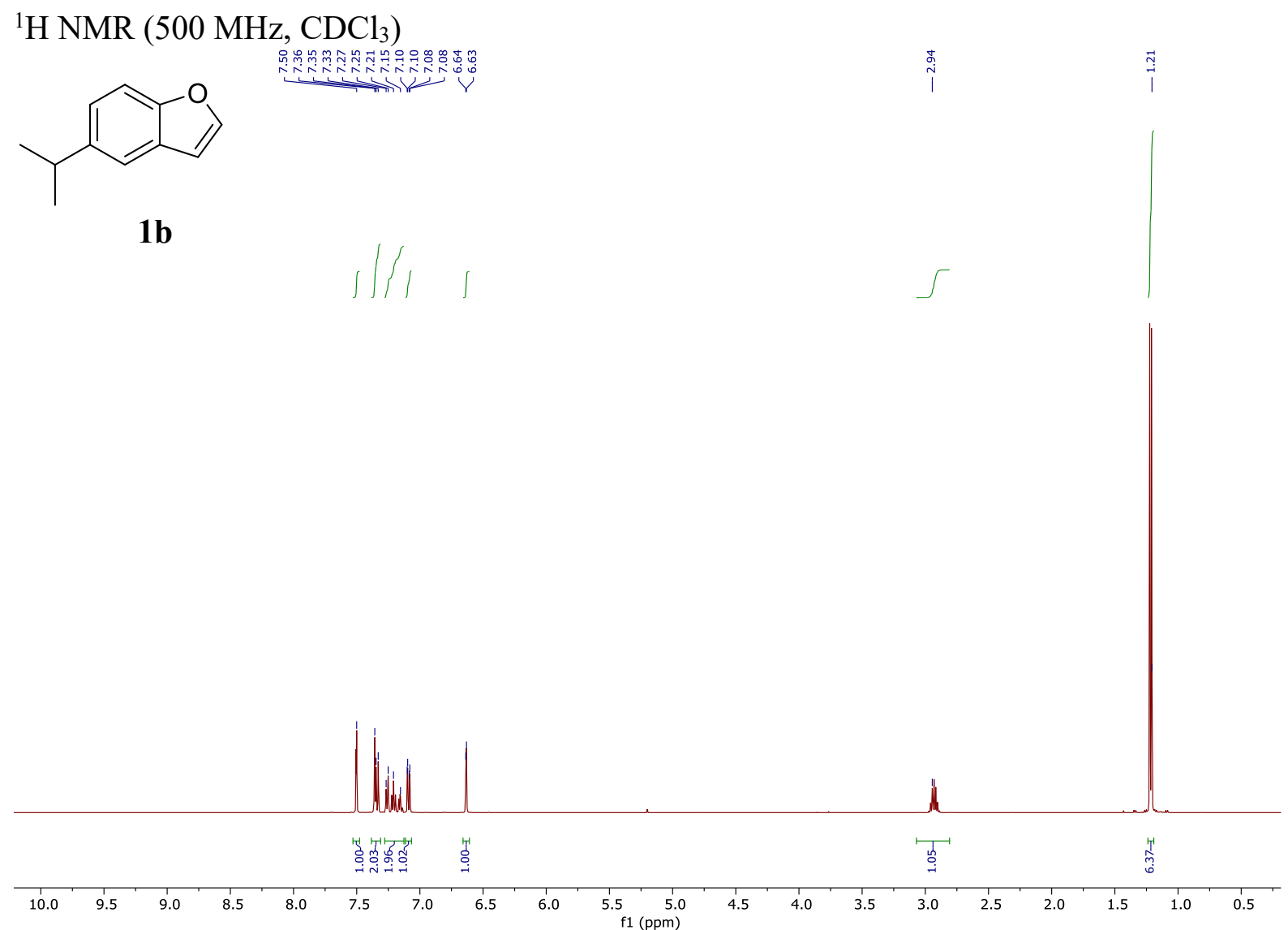

${ }^{13} \mathrm{C}$ NMR (126 MHz, $\left.\mathrm{CDCl}_{3}\right)$

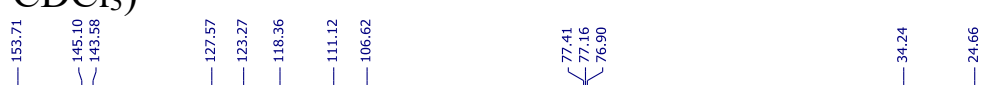

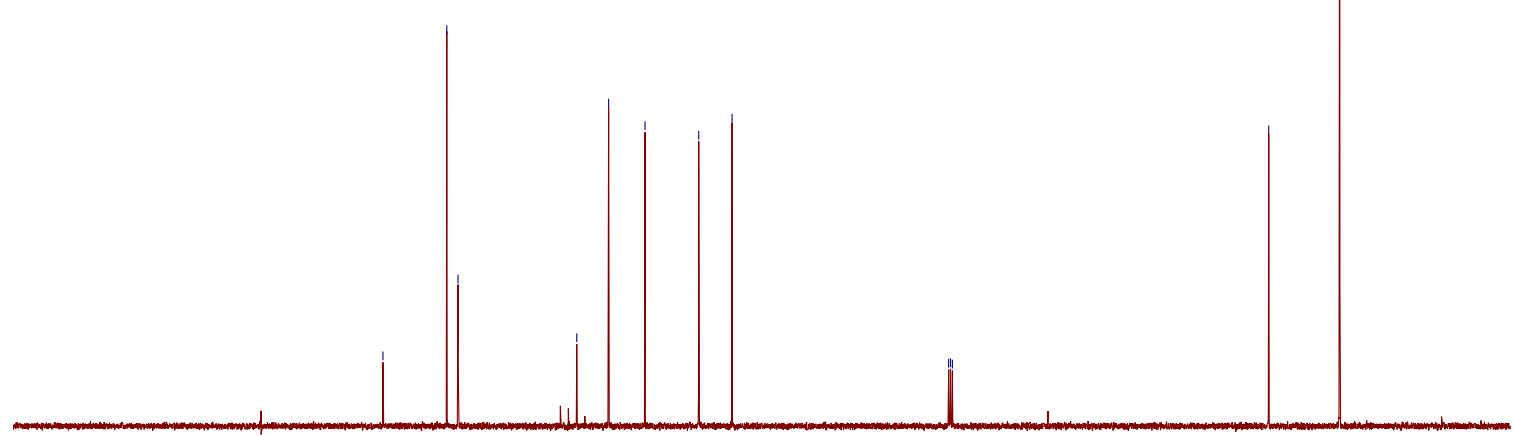

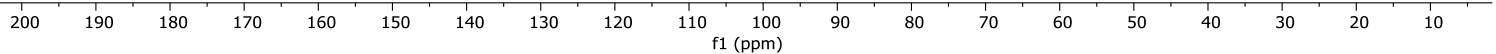


${ }^{1} \mathrm{H}$ NMR (500 MHz, $\mathrm{CDCl}_{3}$ )

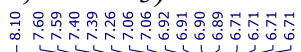<smiles>COc1ccc2occc2c1</smiles>

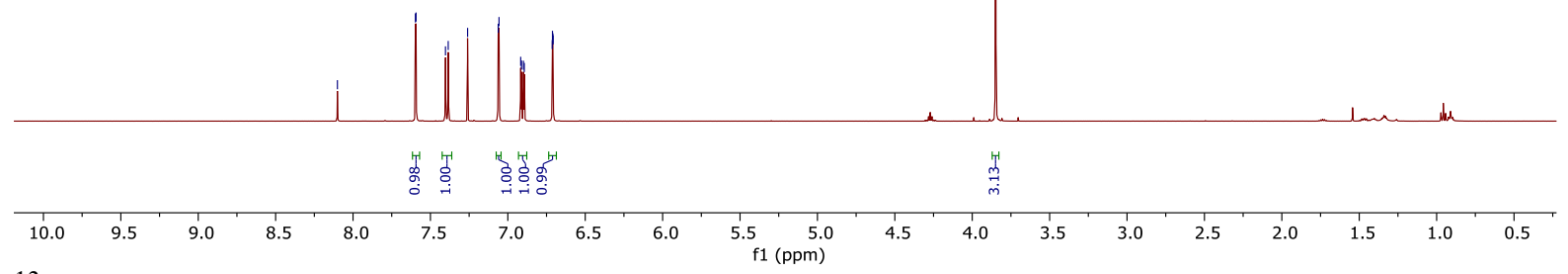

${ }^{13} \mathrm{C}$ NMR (126 MHz, $\mathrm{CDCl}_{3}$ )

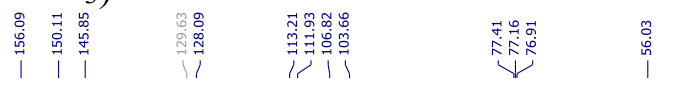

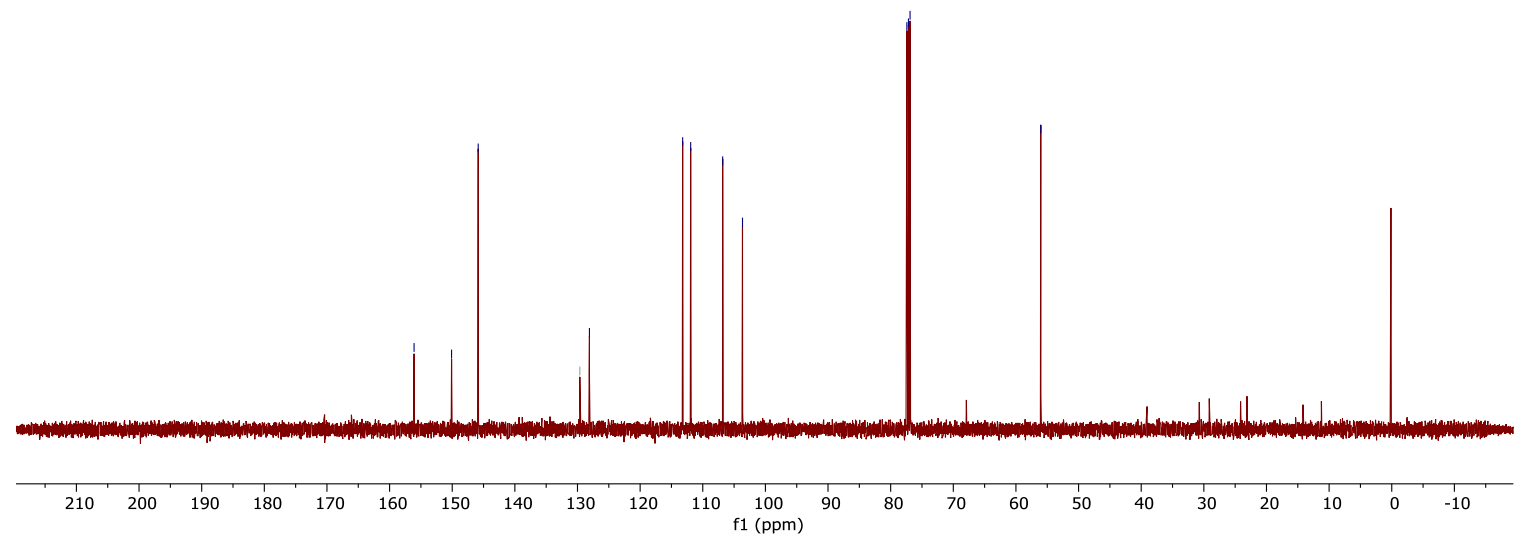


${ }^{1} \mathrm{H}$ NMR $\left(500 \mathrm{MHz}, \mathrm{CDCl}_{3}\right)$<smiles>Brc1coc2ccccc12</smiles>

1d

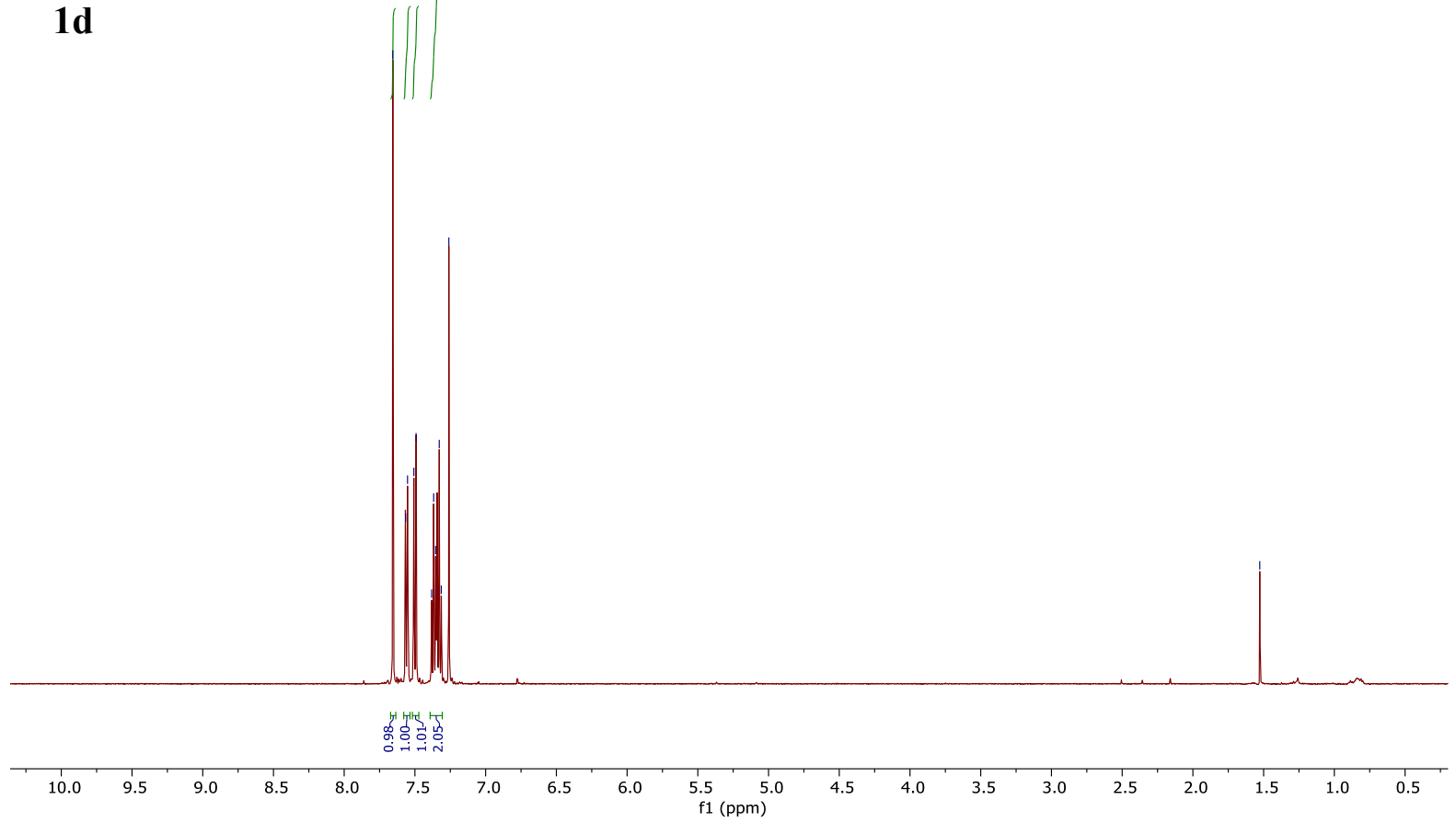

${ }^{13} \mathrm{C}$ NMR (126 MHz, $\left.\mathrm{CDCl}_{3}\right)$

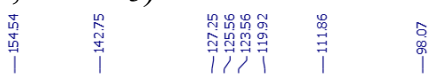

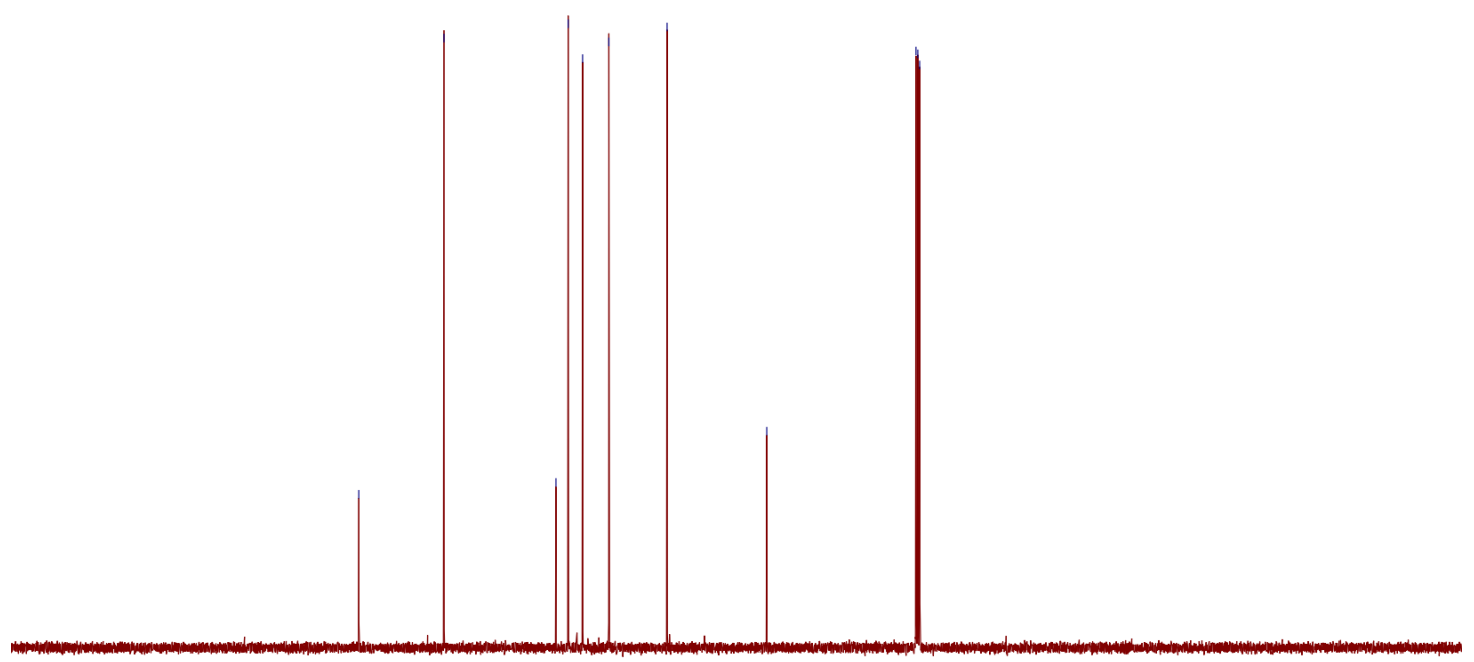

200
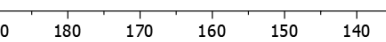
$\begin{array}{lllr}120 & 110 & 100 \\ & & \end{array}$ 